\title{
THE REGULATION OF THE CELL SURFACE PROTEOME BY AMP-ACTIVATED PROTEIN KINASE
}

by

Eden Ross, BScH Queen's University 2012

\author{
A thesis \\ presented to Ryerson University \\ in partial fulfillment of the \\ requirements for the degree of \\ Master of Science \\ in the Program of \\ Molecular Science
}

Toronto, Ontario, Canada, 2014 CEden Ross 2014 


\section{AUTHOR'S DECLARATION FOR ELECTRONIC SUBMISSION OF A THESIS}

I hereby declare that I am the sole author of this thesis. This is a true copy of the thesis, including any required final revisions, as accepted by my examiners.

I authorize Ryerson University to lend this thesis to other institutions or individuals for the purpose of scholarly research.

I further authorize Ryerson University to reproduce this thesis by photocopying or by other means, in total or in part, at the request of other institutions or individuals for the purpose of scholarly research.

I understand that my thesis may be made electronically available to the public. 


\title{
Abstract \\ THE REGULATION OF THE CELL SURFACE PROTEOME BY AMP-ACTIVATED PROTEIN KINASE
}

\author{
Eden Ross
}

Master of Science, Molecular Science, Ryerson University, 2014

The cell-surface proteome controls numerous cellular functions and is dynamically controlled by endocytosis and recycling under different cellular conditions. Energy stress is a state in which a cell must engage adaptive responses to ensure survival, including remodelling of the cell-surface proteome. AMP-activated protein kinase (AMPK) is an important metabolic regulator in the cell. Recent studies suggest AMPK activation may alter the endocytosis of a few specific proteins. How increased AMPK activity globally regulates the cell surface proteome is not known. I have developed a method to isolate the cell surface proteome from cultured cells. Coupling this method to quantitative mass spectrometry has allowed systematic identification of changes in the cell-surface proteome upon metabolic regulation. I found that activation of AMPK results in robust changes in the cell surface proteome, including cell adhesion and migration proteins. I confirmed that AMPK activation elicits a decrease in the cell surface abundance of the adhesion and migration protein $\beta 1$-integrin, and that this is correlated with altered function of the endocytosis protein Dab2. Thus, my research furthers our understanding of how AMPK regulates the cell surface proteome and the specific mechanism by which AMPK regulates cellular adhesion and migration. 


\section{Acknowledgements}

I would like to thank Dr. Costin N. Antonescu for his tireless guidance, supervision, and support. It has been an honour to be a member of his research group.

I would also like to thank my supervisory committee members Drs. John Marshall and Jeffrey Fillingham for their continued help and advice, Thanusi Thavarajah for her help with the mass spectrometry, Pete Bowden for his expertise in mass spectrometry data analysis, my colleagues in the Antonescu lab, and the wonderful staff and faculty at Ryerson University.

I am grateful for all the heartfelt support and encouragement from Benjamin Klein. My family, especially my parents, have been helping me succeed from the beginning and to them I owe great thanks. Finally, I would like to thank my friends for all the great things they do. 


\section{Table of contents}

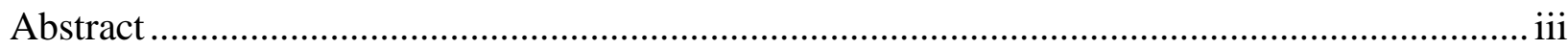

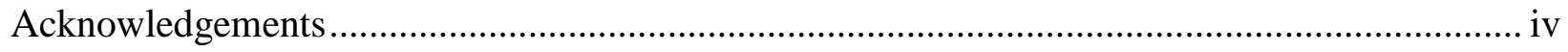

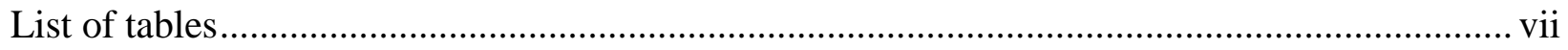

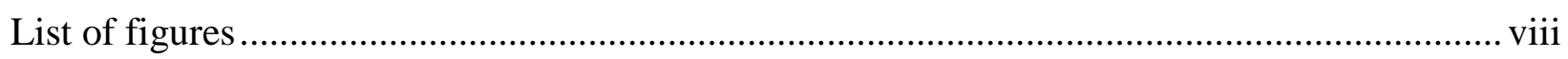

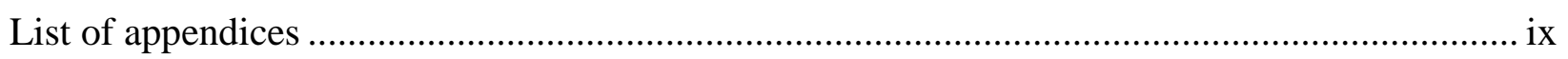

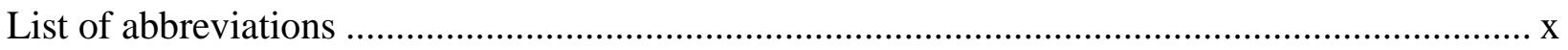

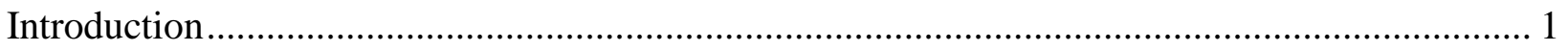

Cell-surface protein membrane traffic …………….............................................................. 2

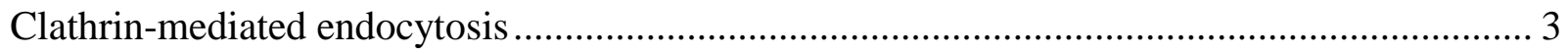

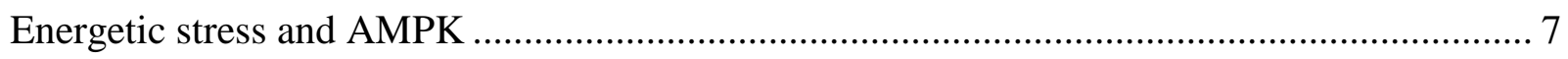

AMPK as a regulator of membrane traffic...................................................................... 10

AMPK in development and migration ............................................................................ 10

Cellular migration and adhesion ........................................................................................ 13

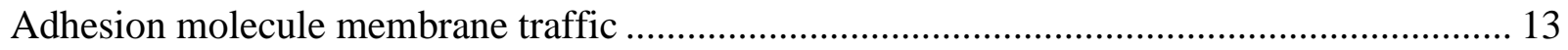

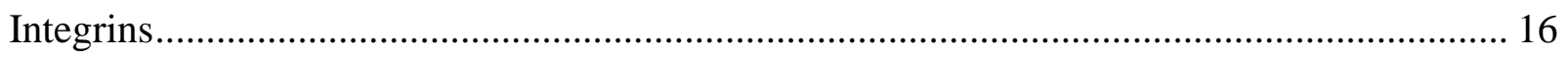

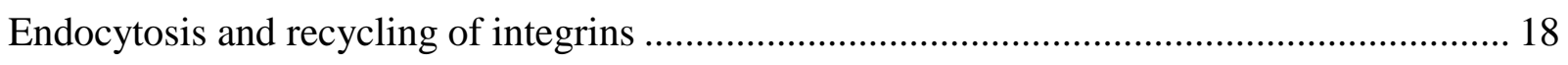

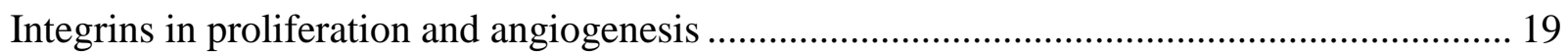

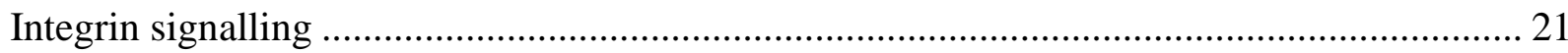

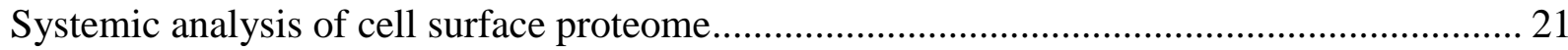

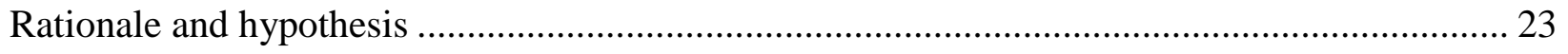

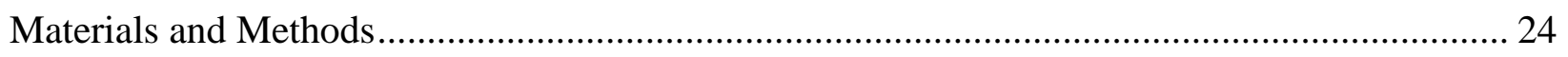

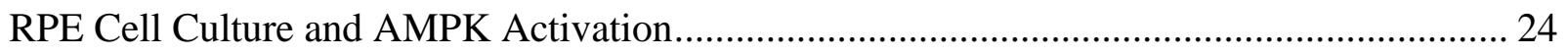

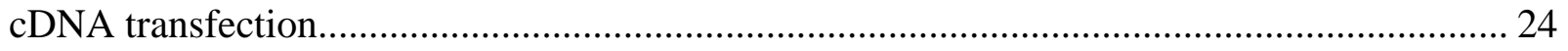

Cell Surface Protein Labelling and Purification ................................................................. 25

Trypsin Digest of Cell Surface Proteins, Zip-Tip Preparation, LC-ESI-MS/MS, and Protein. 26

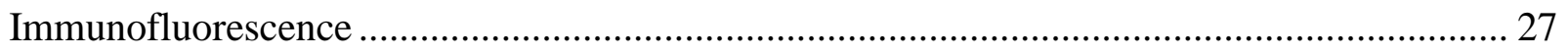

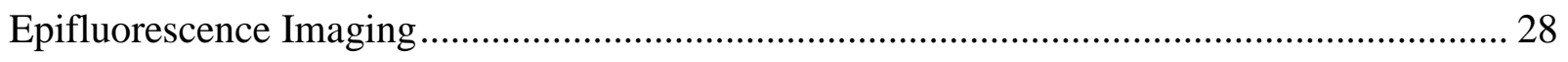

Quantification of cell surface staining and total staining intensity ........................................ 28

TIRF Microscopy Imaging and analysis .......................................................................... 29

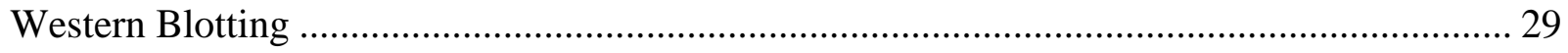




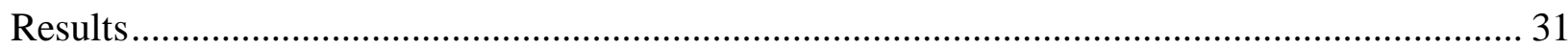

Results Part 1: Regulation of the cell-surface proteome by AMPK ……………………......... 31

Validation and optimization of cell-surface protein purification assay ..................................... 31

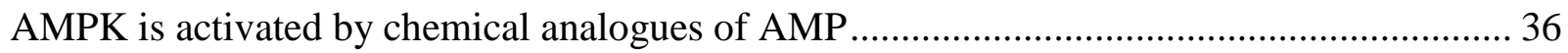

Regulation of the cell surface proteome by AMPK activation ................................................. 38

Results Part II: The specific regulation of $\beta 1$-integrin membrane traffic by AMPK................ 47

$\beta 1$-integrin cell surface content is reduced upon AMPK activation ....................................... 47

Transferrin receptor is not regulated at the cell surface by AMPK activation........................... 49

AMPK activation alters assembly of Dab2-contating CCPs................................................... 50

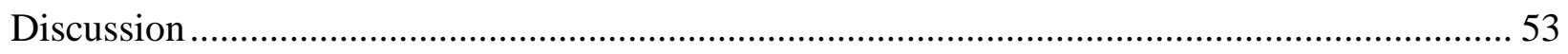

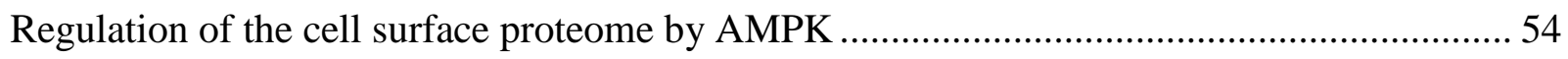

Analysis of changes in the cell surface proteome …………................................................... 55

Coverage of the cell surface proteome by lysine-reactive biotinylation purification strategy.. 57

Benefits of LC-ESI-MS/MS in the quantification of peptide identifications............................. 58

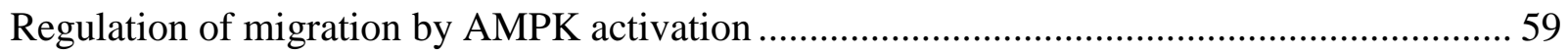

Regulation of $\beta 1$-integrin membrane traffic by AMPK ......................................................... 60

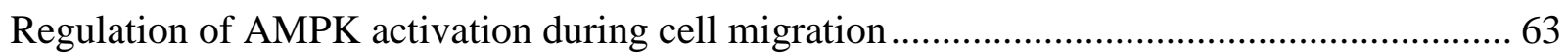

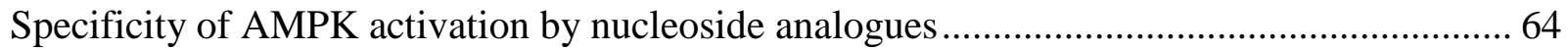

Regulation of integrins and cell migration during cancer: possible role of AMPK.................. 65

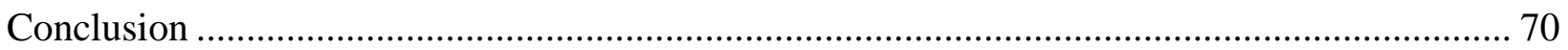

Appendix 1 - Top 100 proteins identified in the cell-surface assay to be depleted at the cell-

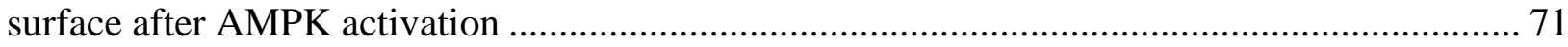

Appendix 2 - Top 100 Proteins identified in the cell-surface assay to be enriched at the cell-

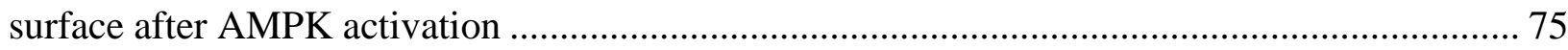

Appendix 3 - Structural diagrams of AMP, ADP, ATP, AICAR, ZMP, and A-769662 …......... 79

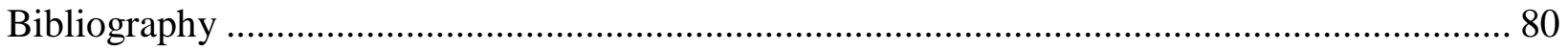




\section{List of tables}

Table 1 Examples of integrin heterodimers and their ligands

Table 2 DAVID GO functional clustering analysis results for proteins depleted at the cell-surface

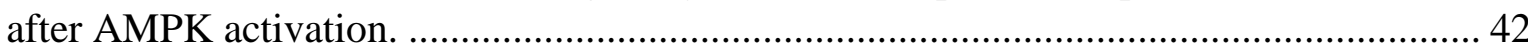

Table 3 DAVID GO functional clustering analysis results for proteins enriched at the cell-surface

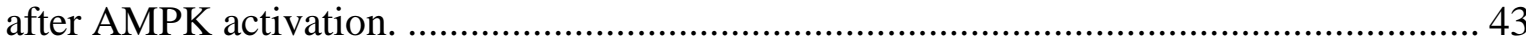

Table 4 Proteins involved in cell adhesion regulated at the cell surface by AMPK activation. The majority of cell surface adhesion proteins were found to be depleted at the cell surface after

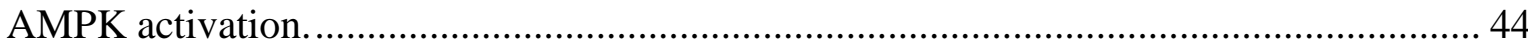




\section{List of figures}

Figure 1 Dynamic regulation of cell surface proteins....................................................

Figure 2 Formation of clathrin-coated vesicles. ............................................................. 4

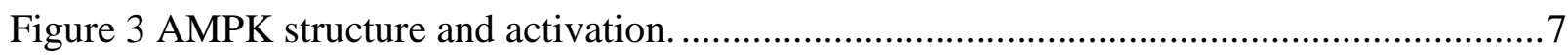

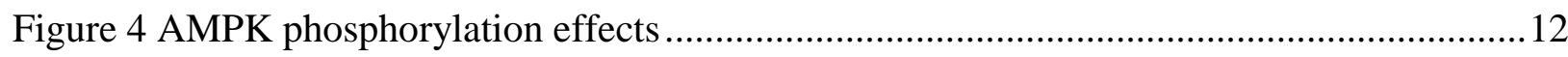

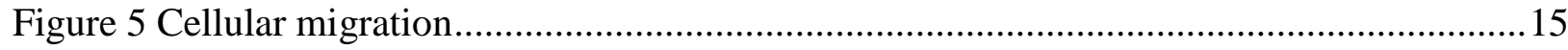

Figure 6 Integrin heterodimers, ECM and cytoskeleton binding ........................................ 17

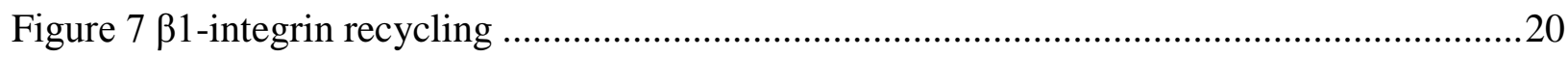

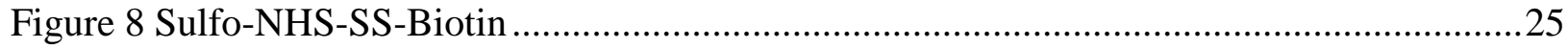

Figure 9 Silverstain gel image of biotinylated proteins .................................................... 32

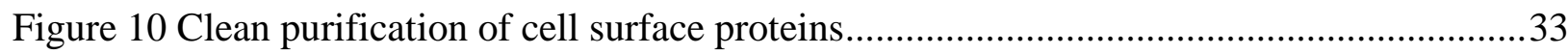

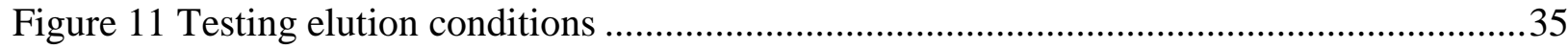

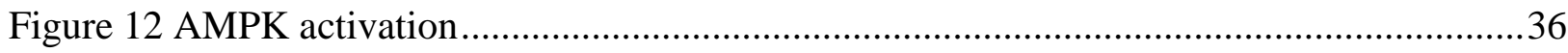

Figure 13 Identification of functional clusters regulated by AMPK ......................................39

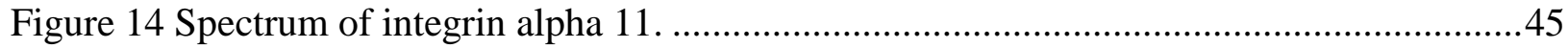

Figure $15 \beta 1$-integrin cell surface content is reduced upon AMPK activation .........................48

Figure 16 AMPK activation does not regulate TfR abundance at the cell surface....................50

Figure 17 AMPK activation alters assembly of Dab2-containing CCPs .................................52

Figure 18 Model - AMPK may regulate adhesion molecule membrane traffic.........................62

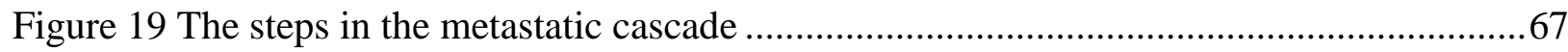




\section{List of appendices}

Appendix 1 - Proteins depleted at the cell-surface after AMPK activation............................. 71

Appendix 2 - Proteins enriched at the cell-surface after AMPK activation............................ 75

Appendix 3 - Structural diagrams of AMP, ADP, ATP, AICAR, ZMP, and A-769662 ........... 79 


\section{List of abbreviations}

Abbot - A-769662

ACC - Acetyl-CoA carboxylase

ADP - Adenosine diphosphate

AICAR - 5-Aminoimidazole-4-carboxamide ribonucleotide; AICA ribonucleotide; Acadesine

AMP - Adenosine monophosphate

AMPK - AMP-activated protein kinase

AP-2 - Adaptor complex 2

ARRDC - Arrestin-domain-containing protein

ATP - Adenosine triphosphate

bFGF - Basic fibroblast growth factor

$\mathrm{BM}$ - Basement membrane

BSA - Bovine Serum Albumin

$\mathrm{CaMKK}-\mathrm{Ca}^{2+} /$ calmodulin-dependent kinase kinase

$\mathrm{CCP}$ - Clathrin coated pit

$\mathrm{CCV}$ - Clathrin coated vesicle

$\mathrm{CD}$ - Cluster of differentiation

$\mathrm{CHC}$ - Clathrin heavy chain

CLASP - Clathrin-associated sorting protein

CLC - Clathrin light chain

CME - Clathrin mediated endocytosis

Dab2 - Disabled-2

DTT - dithiothreitol

EAP - Endocytic accessory protein

ECM - Extracellular matrix

EE - Early endosome

EGF - Epidermal growth factor

EGFR - Epidermal growth factor receptor

EH - Eps-homology

ESI - electrospray ionization 
f-actin - Filamentous actin

FAK - Focal adhesion kinase

FBS - Fetal bovine serum

GDP - Guanosine diphosphate

GFP - Green fluorescent protein

GLUT-1 - Glucose transporter 1

GLUT-4 - Glucose transporter 4

GO - Gene ontology

GTP - Guanosine triphosphate

HAX1 - HCLS1-associated protein

LC-ESI-MSMS - Liquid chromatography electrospray ionization tandem mass spectrometry

LDL - Low density lipoprotein

LDL-R - Low density lipoprotein receptor

LKB-1 - Liver kinase B1

LSB - Laemmli Sample Buffer

MALDI - matrix-assisted laser desorption ionization

MHC - Major Histocompatibility Complex

MMP - Matrix metalloproteinase

MS - Mass spectrometry

MudPIT - Multidimensional protein identification technology

NA - Numerical Aperture

NHS $-N$-hydroxysuccinimide

$O$-GlcNAc - $O$-linked $\mathrm{N}$-acetylglucosamine

OGT - $O$-linked $\mathrm{N}$-acetylglucosamine transferase

p- - Phospho-

p130CAS - P130 CRK-associated substrate

p38 MAPK - p38 mitogen-activated protein kinase

PBS - Phosphate buffered saline

PFA - Paraformaldehyde

$\mathrm{PIP}_{2}$ - Phosphatidylinositol-(4,5)-bisphosphate

PIP5K - Phosphatidylinositol-4-phosphate-5-kinase 
PKC - Protein kinase C

PM - Plasma membrane

PY - Phosphotyrosine

RE - Recycling endosome

RPE - Retinal pigment epithelial cells

SDS - Sodium dodecyl sulfate

SDS PAGE - SDS Polyacrylamide gel electrophoresis

SFK - Src family kinase

SILAC - Stable isotope labeling by amino acids in cell culture

SS - Disulphide

Tfn - Transferrin

TfR - Transferrin receptor

TIRFM - Total internal reflection fluorescence microscopy

TXNIP - Thioredoxin-interacting protein

VALAP - Vaseline, Lanolin, Parafin wax

ZMP - 5-Aminoimidazole-4-carboxamide ribonucleoside 


\section{Introduction}

Proteins on the surface of cells control numerous aspects of cellular function including signaling, nutrient uptake, and adhesion. The profile of all the proteins on the cell surface is termed the "cell surface proteome". These proteins exact their function by necessarily gaining access to the extracellular milieu - extracellular matrix proteins, hormones, nutrients, and so on. Nutrient transporters and carriers are crucial for obtaining essential nutrients and regulating their metabolic balance within the cell. For example, Glucose Transporter type 1 (GLUT-1) is an important sugar transporter responsible for the uptake of glucose into the cell. GLUT-1 deficiency is implicated as a cause of severe learning difficulties and developmental delay (Gordon \& Newton, 2003). Adhesion molecules are responsible for forming contact sites with the extracellular matrix (ECM) or with other cells. Integrins are adhesion proteins that facilitate coupling of the ECM to the cytoskeleton and regulate cellular adhesion and migration.

The surface of a cell is not a static compartment as the cell surface proteome is dynamically regulated by multiple cellular mechanisms in response to changing cellular conditions. Remodelling of the cell surface proteome plays an important role in cell growth and differentiation. For example, such remodelling is crucial for cell type determination in T-cell development: $\mathrm{CD} 48^{-}$progenitor cells transition through a double-positive $\left(\mathrm{CD} 4^{+} 8^{+}\right)$stage where both MHC coreceptors are present on the cell surface before maturing into single-positive thymocytes with only one coreceptor in the $\mathrm{PM}\left(\mathrm{CD}^{+} 8^{-}\right.$or $\left.\mathrm{CD}^{-} 8^{+}\right)$. Plasticity of the cell surface proteome is a key feature that allows cells to respond to changing environments and metabolic states. Changes in the cell surface proteome may be long-term/chronic and result from changes 
in expression of different cell surface proteins, or these changes may be short-term/acute and result from changes in membrane traffic.

\section{Cell-surface protein membrane traffic}

Perturbing the abundance of cell surface proteins may have vast implications on general cell health and maintenance. Proteins are regulated at the cell surface by their biosynthesis, degradation, endocytosis, recycling, and exocytosis (Figure 1). The cell surface proteome can be dramatically different between different cell types and between healthy and diseased cells of the same type (Billah et al., 2011; Hynes, 1976; Shin et al., 2003; Sun, 2012).

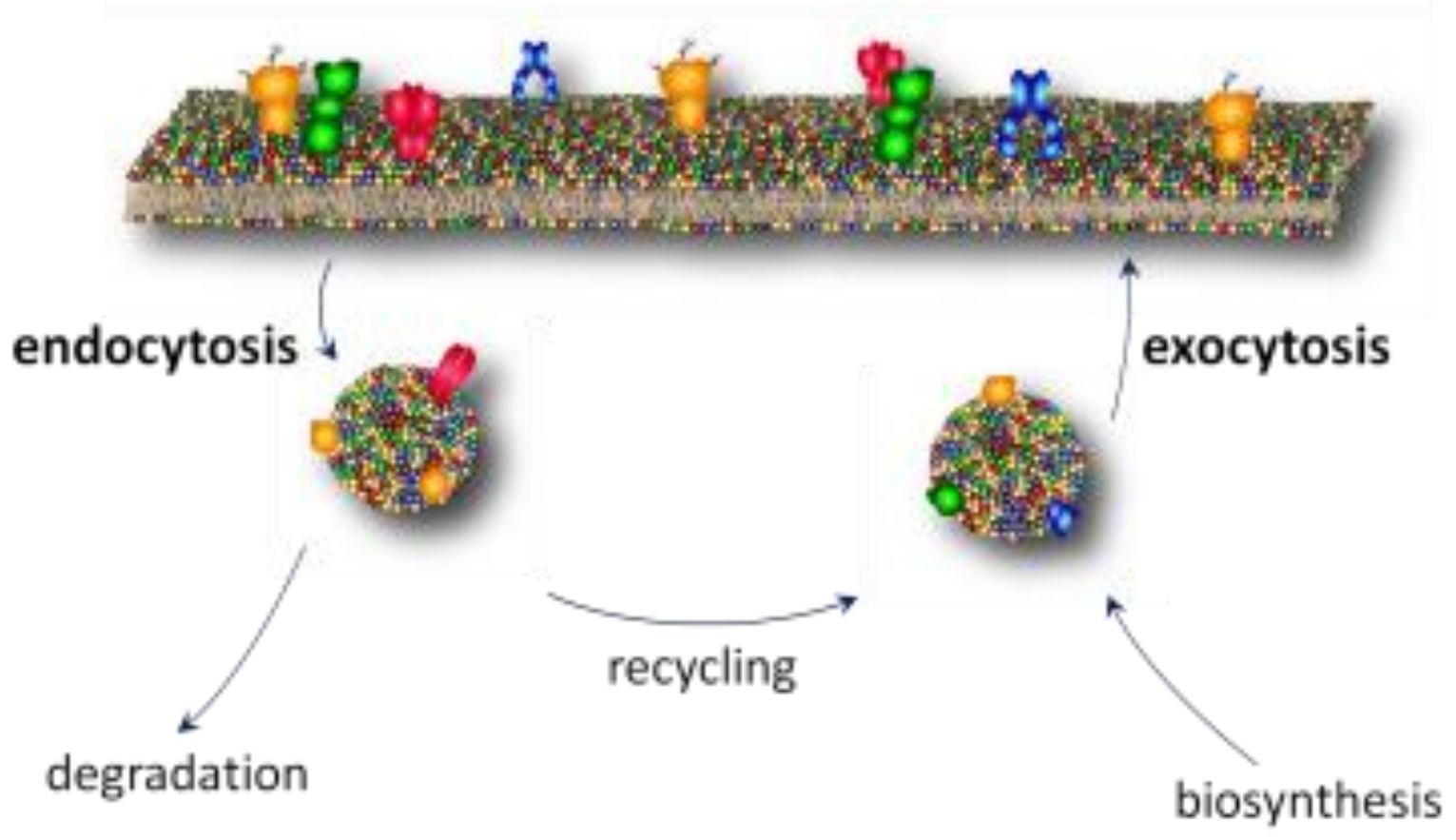

Figure 1 Cell surface proteins are involved in many important functional pathways. Cell surface proteins are regulated by multiple cellular mechanisms including endocytosis, degradation, recycling, biosynthesis, and exocytosis. 
Regulation of endocytosis is one way to impact cell surface content. If endocytosis of a protein is interrupted, the interruption will result in an accumulation of that protein on the cell surface. Increasing the rate of endocytosis of a protein, on the other hand, would result in a decrease in the cell surface content of that protein.

\section{Clathrin-mediated endocytosis}

Clathrin-mediated endocytosis (CME) is the principal route of internalization for membrane proteins and initiates by recruitment of clathrin and other proteins to cargo (protein)enriched areas of the plasma membrane (PM) known as clathrin-coated pits (CCPs). Clathrin and other proteins assemble on the inner leaflet of the plasma membrane, a process during which the plasma membrane becomes invaginated at the sites of CCPs. At any time, hundreds of CCPs are found in a cell (Traub, 2009). After a maturation stage, CCPs may eventually undergo scission from the PM to yield intracellular clathrin-coated vesicles (CCVs). The net result of formation of a CCV is the transfer of specific proteins from the cell surface into intracellular vesicles and subsequently endosomes (Figure 2).

There are many proteins and lipids that are required for the formation of a $\mathrm{CCP}$ leading to a $\mathrm{CCV}$, underlying the complexity of this process. Despite the complexity of the formation of CCPs, some key molecules emerge: 1) clathrin, which self-assembles to form a scaffold, 2) AP2, which binds to clathrin, cargo proteins, and the membrane, 3) Phosphatidylinositol-(4, 5)bisphosphate ( $\left.\mathrm{PIP}_{2}\right)$, which is the main lipid binding partner of the PM for CME proteins including AP-2, and 4) cargo proteins, which are also bound and recruited by AP-2. 


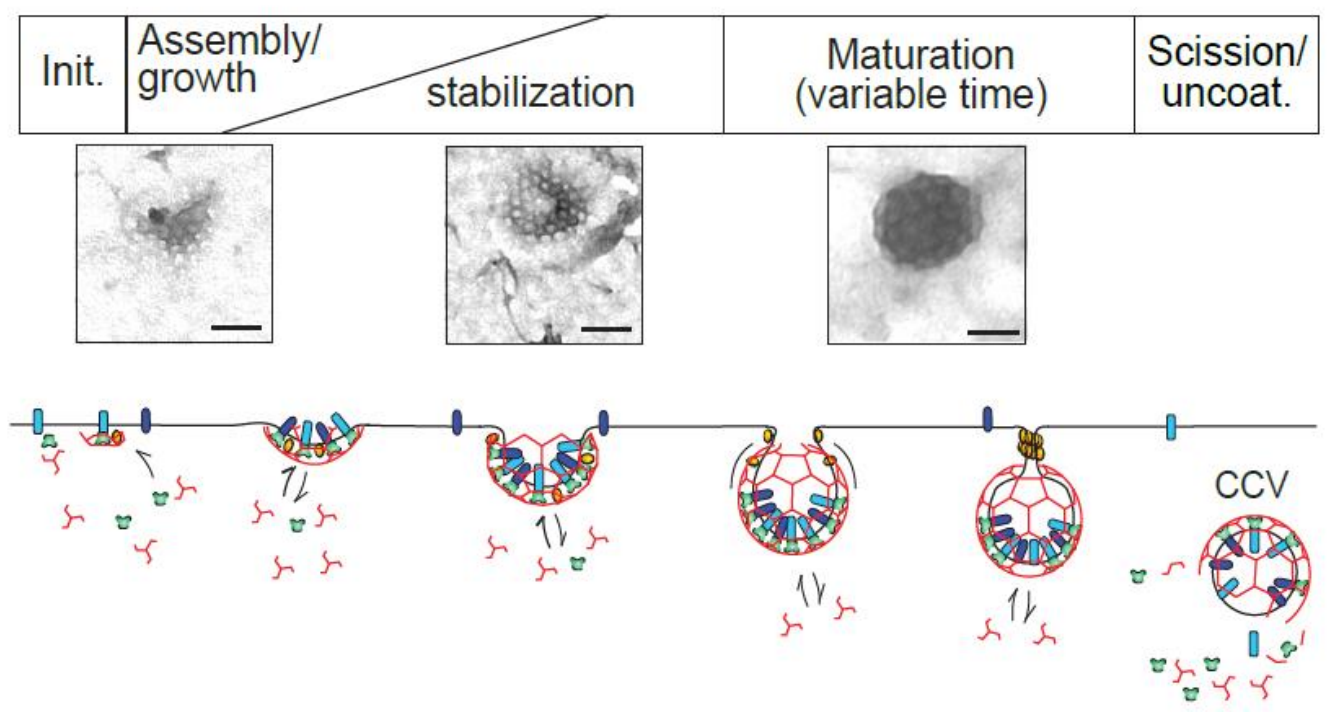

Figure 2 Formation of clathrin-coated vesicles occurs as a result of regulated initiation, assembly, maturation and scission of clathrin-coated pits. CME initiates by recruitment of clathrin, AP-2, and other proteins to cargo-enriched areas of the PM known to assemble CCPs. After maturation, CCPs undergo dynamin-dependent scission from the PM to yield intracellular CCVs. Upon internalization, the clathrin coat disassembles

Clathrin, a protein first isolated in 1975 by Barbara Pearse (Pearse, 1976), is the scaffold molecule in CME. It forms a triskelion shape with three clathrin light chains and three clathrin heavy chains. Clathrin self-assembles into a polyhedral basket-like structure that stabilizes early endocytic structure and facilitates CME (Brodsky, Chen, Knuehl, Towler, \& Wakeham, 2001). The $190 \mathrm{kDa}$ clathrin heavy chain C-terminus binds many accessory factors that regulate the progression of endocytosis (Schmid \& McMahon, 2007; ter Haar, Harrison, \& Kirchhausen, 2000). This feature of clathrin is why it is considered a major interaction hub of endocytosis.

The adaptor protein complex AP-2 is considered another interaction hub in endocytosis. AP-2 is a heterotetrameric protein complex with a trunk domain that binds to cargo and lipids, and two appendage domains, connected to the trunk with flexible linkers, that bind to many accessory proteins when concentrated in forming CCPs (Brett \& Traub, 2006; Owen et al., 1999; Schmid \& McMahon, 2007). AP-2 binds to clathrin, endocytic cargo, and accessory proteins 
and so mediates cargo recruitment, maturation, and scission of the CCP. Some accessory proteins that AP-2 binds include the Eps-homology $(\mathrm{EH})$ domain proteins Eps15 and intersectin.

$\mathrm{PIP}_{2}$ is the main lipid binding partner of the PM for CME proteins including AP-2 and is another interaction hub in endocytosis. It is crucial for the recruitment of proteins to CCPs for CME and regulates CCP initiation, stabilization and size (Antonescu, Aguet, Danuser, \& Schmid, 2011). PIP 2 synthesis is largely a result of phosphatidylinositol-4-phosphate-5-kinase (PIP5K) phosphorylation of phosphatidylinositol-4-phosphate in mammalian cells (Doughman, Firestone, \& Anderson, 2003).

CME cargo proteins are cell surface receptors and their bound ligands. Internalization of cargo proteins regulates their abundance at the cell surface but cargo can regulate CME as well (Loerke et al., 2009; Mettlen, Loerke, Yarar, Danuser, \& Schmid, 2010; Wilde et al., 1999). For example, EGFR is a transmembrane receptor protein responsible for the internalization and signaling of EGF. Ligand-bound EGFR stimulates Src phosphorylation of clathrin which influences clathrin redistribution and EGF uptake (Wilde et al., 1999).

There are approximately 30-50 other proteins that are recruited to CCPs in addition to the four "key" molecules described above. Some are required for membrane bending such as BAR domain or ENTH-domain containing proteins and others, such as clathrin-associated sorting proteins (CLASPs) are required for the incorporation of specific cargoes to CCPs and for their internalization. CLASPs are involved in the endocytosis of some cargoes (Traub, 2009). For example, Dab2 is a CLASP that is required for the endocytosis of specific cargo, such as LDL-R and $\beta 1$-integrin. Dab2 contains a phosphotyrosine (PY)-binding domain that recognizes $\mathrm{PIP}_{2}$ and the FxNPxY internalization motif found in LDL-R and $\beta 1$-integrin (Morris \& Cooper, 2001; Chao \& Kunz, 2009; Ezratty, Bertaux, Marcantonio, \& Gundersen, 2009; Teckchandani et al., 
2009). Like AP-2, Dab2 also binds to EH-domain containing proteins Eps15 and intersectin (Teckchandani, Mulkearns, Randolph, Toida, \& Cooper, 2012).

There are hundreds to thousands of cell surface proteins; however three proteins, EGFR, transferrin (Tfn) receptor (TfR) and Low-Density Lipoprotein (LDL) receptor (LDL-R) are studied and used as general representatives of all cell surface proteins. Studies have shown that their endocytosis mechanisms and regulation are different (Antonescu et al., 2010; Loerke et al., 2009; Mettlen et al., 2010). Specifically, TfR requires TTP for its internalization, EGFR requires Epsin or Grb2, and LDLR requires ARH/Dab2. Recent developments in CME research have shown that CCPs are heterogeneous (Antonescu, Mcgraw, \& Klip, 2014; Loerke et al., 2009; Mettlen et al., 2010) and that CME as well is a heterogeneous process that exhibits distinct mechanisms and regulation for the endocytosis of distinct receptors.

Most vesicular carriers originating from the PM are targeted to the early endosome, an organelle with specific proteins such as EEA1 and Rab5. From here, proteins are either sorted to the degradative pathway (in lysosomes, through traffic to late endosomes and then multivesicular bodies) or recycled back to the PM either directly or through a separate Rab11-positive membrane compartment.

While there is much to be learned about the molecular mechanisms that underlie endocytosis, it is now clear that different receptors (i.e. TfR and LDLR) can be distinctly regulated by CME, in part due to their differential use of CLASPs like Dab2. Not only does CME need to differentially regulate the cell surface levels of different proteins, but it also has to adjust this regulation to meet the changing needs of a cell. One of the most critical parameters of the cell that needs to be regulated in order to ensure homeostasis and survival is energy. 


\section{Energetic stress and AMPK}

ATP is the powerhouse molecule that allows cells to undergo many energetically demanding processes. Phosphodiester bonds within ribonucleoside phosphates are the energy currency of the cell, and the end product of glycolysis and oxidative phosphorylation is ATP production. Fuel sources for ATP production primarily include glucose and fatty acids in most cell types. Adenylate kinase catalyzes the reaction $2 \mathrm{ADP} \leftrightarrow \mathrm{ATP}+\mathrm{AMP}$ which is maintained close to equilibrium in most eukaryotic cells (G. D. Hardie, 2014). In unstressed cells, catabolism maintains the ATP:ADP ratio at around 10:1, which drives the adenylate kinase reaction towards ADP so that low levels of AMP are maintained.

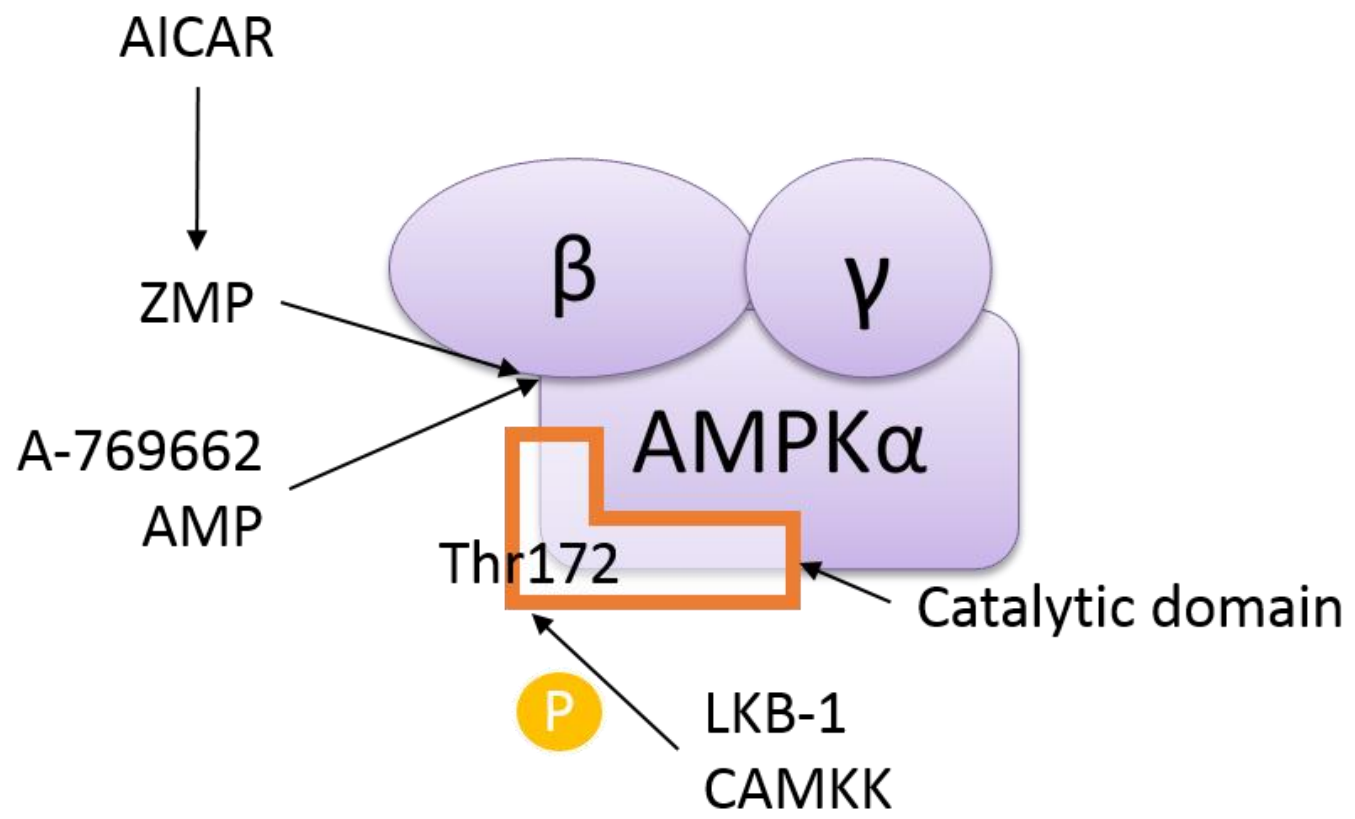

Figure 3 AMPK is a heterotrimeric complex comprised of a catalytic alpha subunit and beta and gamma regulatory subunits (Mitchelhill et al., 1994). AMPK is phosphorylated at threonine 172 within the catalytic domain of the alpha subunit by LKB-1 or CAMKK. AICAR is converted to ZMP upon internalization. ZMP, A-769662, and AMP bind to the regulatory beta subunit near the alpha catalytic domain (G. D. Hardie, 2014) 
Certain physiological conditions (e.g. muscle contraction, lung cell hypercapnia) can result in dramatic changes in ATP levels (Antonescu et al., 2014). When cells experience this metabolic stress, the ATP:ADP ratio falls and the adenylate kinase reaction is displaced towards AMP (Gowans, Hawley, Ross, \& Hardie, 2013). AMP concentration starts at a very low level so the changes in stressed cells are always much larger than the changes in ATP or ADP levels (Gowans et al., 2013). Therefore cellular AMP concentration is a sensitive indicator of energy stress. AMP-activated protein kinase (AMPK) is a metabolic stress sensor of the cell that is responsible for detecting and correcting energetic stress. AMPK becomes activated after recognizing a decrease in the AMP:ATP ratio. Activated AMPK directly and indirectly enacts many cellular responses that allow the cell to return to a metabolically favourable state.

AMPK is a heterotrimer that is structurally and functionally homologous with the yeast protein Snf1 (Mitchelhill et al., 1994). AMPK has a catalytic alpha ( $\alpha 1$ or $\alpha 2)$ subunit and beta ( $\beta 1$ or $\beta 2$ ) and gamma $(\gamma 1, \gamma 2$, or $\gamma 3$ ) non-catalytic subunits (Figure 3) (Mitchelhill et al., 1994). At the ATP concentrations typically found in an unstressed state, AMPK favours binding ATP over AMP, given the different relative affinity of the kinase for these two molecules (Gowans et al., 2013). In metabolic stress conditions, as the concentration of ATP drops, the ratio of AMP:ATP increases and AMPK favours binding to AMP. AMP binding to AMPK results in a conformational change exposing threonine 172 on the alpha subunit of AMPK that can be phosphorylated by the tumour suppressor liver kinase B1 (LKB-1) or by $\mathrm{Ca}^{2+} /$ calmodulindependent kinase kinase (CaMKK) (Corton, Gillespie, Hawley, \& Hardie, 1995). Phosphorylated AMPK is active and can rapidly alter cellular metabolism.

AMPK can be regulated by post-translational modifications such as $O$-GlcNAcylation and phosphorylation. AMPK $\alpha$ - and $\gamma$ - subunits are $O$-GlcNAcylated by $O$-GlcNAc transferase 
(OGT) and this modification on the $\gamma$-subunit of AMPK increases AMPK activity (Bullen et al., 2014). AMPK shuttles between the nucleus and the cytoplasm under normal growth conditions (Kodiha, Rassi, Brown, \& Stochaj, 2007). This localization can be controlled by phosphorylation by other kinases such as Erk which are in turn regulated by a variety of stimuli and can be perturbed in stress-conditions (Kodiha et al., 2007). Hence, the physiological action of AMPK may be controlled not only by its intrinsic affinity of specific substrate proteins, but also by its O-GlcNAcylation and by its cellular compartmentalization.

AMPK's effects can acutely phosphorylate its own downstream targets and also exhibits certain long-term effects by influencing gene transcription (Figure 4). In order to conserve cellular energy, AMPK inhibits anabolic pathways and activates catabolic pathways in response to metabolic stress (Chen et al., 1999).

Activated AMPK phosphorylates (and thereby inactivates) acetyl-coA carboxylase (ACC) to down-regulate fatty acid synthesis and promote fatty acid oxidation. ACC is an enzyme that makes malonyl-CoA. Malonyl-Coa is the building block for fatty acid production and is also an inhibitor of the carnitine acyltransferase, which is the first step in fatty acid breakdown to make ATP. So by phosphorylating and inhibiting ACC, the cell shifts to burning more fatty acids to make more ATP. 


\section{AMPK as a regulator of membrane traffic}

In addition to controlling the enzymatic activity of metabolic enzymes and to regulating gene transcription, AMPK is also emerging as a key regulator of membrane traffic (Antonescu et al., 2014). For example, AMPK phosphorylates and promotes the degradation of thioredoxininteracting protein (TXNIP), an arrestin-domain-containing protein (ARRDC) that promotes GLUT1 internalization through CCPs (Antonescu et al., 2014; Wu et al., 2013). Therefore AMPK induced degradation of TXNIP will result in increased plasma membrane GLUT1 levels, allowing for increased glucose uptake and ATP generation. Furthermore, AMPK activation in muscles increases GLUT4 (another glucose transporter) presence at the cell surface (Antonescu, Díaz, Femia, Planas, \& Klip, 2008; Xi, Han, \& Zhang, 2001). The cell surface pump protein $\mathrm{Na}^{+} / \mathrm{K}^{+}$-ATPase consumes up to $30 \%$ of resting ATP in some cells (Antonescu et al., 2014). AMPK activation results in the internalization and consequential inactivation of $\mathrm{Na}^{+} / \mathrm{K}^{+}$-ATPase which may preserve cellular ATP levels.

Since AMPK plays a central role in the control of glucose homeostasis and lipid metabolism, it is an important therapeutic target in Type 2 Diabetes and obesity. Low-level activation of AMPK is likely to contribute to the global rise in obesity and diabetes (D. G. Hardie, 2011). The role of AMPK in regulating systemic metabolism may be primarily due to AMPK in muscle and liver (G. D. Hardie, 2014).

\section{AMPK in development and migration}

AMPK also plays other roles in many other cell types, as can be seen by the fact that a double AMPK $\alpha 1 / \alpha 2$ knockout mouse is embryonic lethal (Viollet et al., 2009). The role of 
AMPK in other cell types is poorly understood however there is some evidence of a link between AMPK and cell polarity and cell migration (D. G. Hardie, 2011; Kanellis et al., 2006). Activation of AMPK reduces cell adhesion in endothelial progenitor cells (Kaiser, Friedrich, Chavakis, Böhm, \& Friedrich, 2012), and reduces cell migration in vascular smooth muscle cells (Liang et al., 2008), U937 monocytes (Kanellis et al., 2006), and glioblastoma cells (Ferla, Haspinger, \& Surmacz, 2012). The molecular mechanism by which AMPK may control cell adhesion and migration is unknown. 


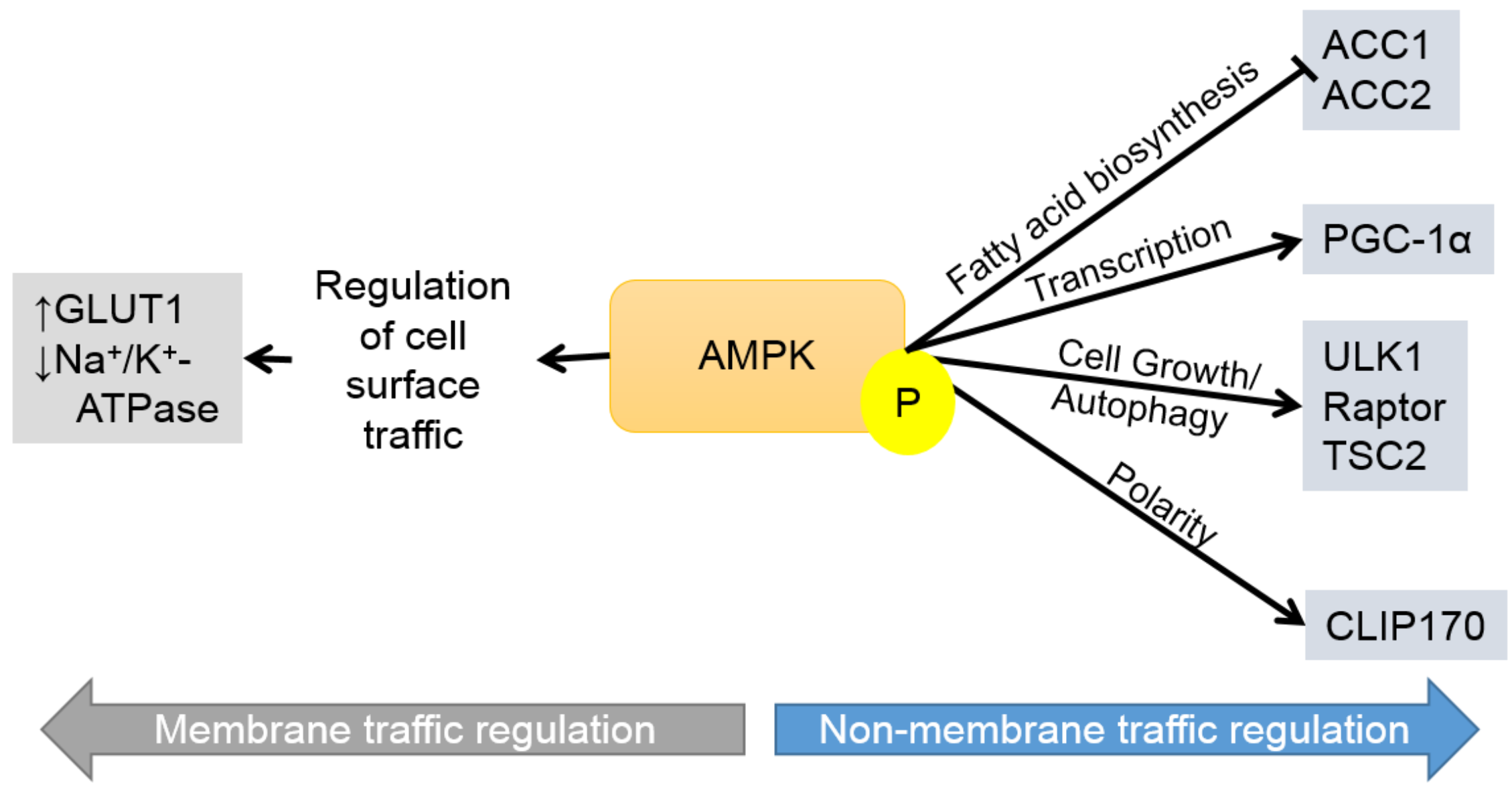

Figure 4 AMPK phosphorylation is implicated in many cellular responses to metabolic stress. Fatty acid biosynthesis is inhibited after activated AMPK phosphorylates ACC1 and 2. PGC-1 $\alpha$, ULK1, Raptor, TSC2 and CLIP170 are other proteins involved in important cellular responses known to be phosphorylated by AMPK activation. Increased GLUT1 at the cell surface and decreased $\mathrm{Na}+/ \mathrm{K}+-\mathrm{ATPase}$ at the cell surface have been shown, however the mechanism has not been elucidated. 


\section{Cellular migration and adhesion}

Cell migration is the process by which cells move throughout their environment. This process requires cells to polarize distribution of certain key PM proteins and extend protrusions (large, broad lamellipodia; long, thin pseudopodia; or spike-like filopodia) according to the direction of travel. Lamellipodia and filopodia formation are driven by actin polymerization and are stabilized by adherence to the ECM or adjacent cells. These adhesions form traction sites for migration as the cell moves forward over them and are disassembled at the cell rear allowing for detachment (Figure 5) (Ridley et al., 2003).

Maintenance of a polarised state in migration requires active focal adhesion disassembly and coordinated adhesion molecule membrane traffic so that new contacts can form near the front of the cell (M. C. Jones, Caswell, \& Norman, 2006). Cell migration involves cell deformation and deformations of the surrounding tissue as the migrating cell moves along (Lange \& Fabry, 2013). These cellular deformations are coupled to a build-up of mechanical stresses that must be overcome by generation of mechanical forces by cytoskeletal proteins (Lange \& Fabry, 2013).

\section{Adhesion molecule membrane traffic}

Integrins are a family of adhesion molecules involved in interactions between the cell and the extracellular matrix (ECM) that surrounds the cell. Past descriptions of integrin membrane traffic led to proposals that endocytosis and recycling drive cell migration by moving adhesion receptors from the back to the front of moving cells (Bretscher, 1996). Although there is not yet evidence that this long-range transport operates during cell migration, recent discoveries show 
that Rab21-positive endosomes mediate the redistribution of integrins from one end of the cell to the other during cytokinesis (Pellinen et al., 2006).

On the other hand, the influence of integrin trafficking on cell migration is likely mediated by modulating Rho GTPase signalling (White, Caswell, \& Norman, 2007) and by controlling the spatial restriction of integrins (P. T. Caswell et al., 2007). Rab proteins are members of the Ras superfamily of GTPases that function in endomembrane traffic by acting as molecular switches that oscillate between GTP- and GDP-bound conformations. The GTP-bound form is active and the regulatory function of Rab proteins is restricted to the compartment where they are localized. While the function of some Rab proteins like Rab5 are mostly ubiquitous, affecting the early endosome membrane traffic of a large number of proteins, the function of some Rab proteins appears to be more selective for some cargo.

The Rab11 subfamily, comprised of Rab11a, Rab11b, and Rab25 (also known as Rab11c), controls the recycling of internalized membrane proteins to the cell surface (Galvez, Gilleron, Zerial, \& O’Sullivan, 2012; Zerial \& McBride, 2001). Rab25 is expressed exclusively in epithelial tissues and promotes a mode of migration on three-dimensional matrices that is characterized by the extension of long pseudopodia (P. T. Caswell et al., 2007). Rab25 directly interacts with the $\beta 1$ integrin cytoplasmic tail and promotes the localization of vesicles that deliver integrins to the PM at the pseudopodial tips at the leading edge of a migrating cell (P. T. Caswell et al., 2007). 


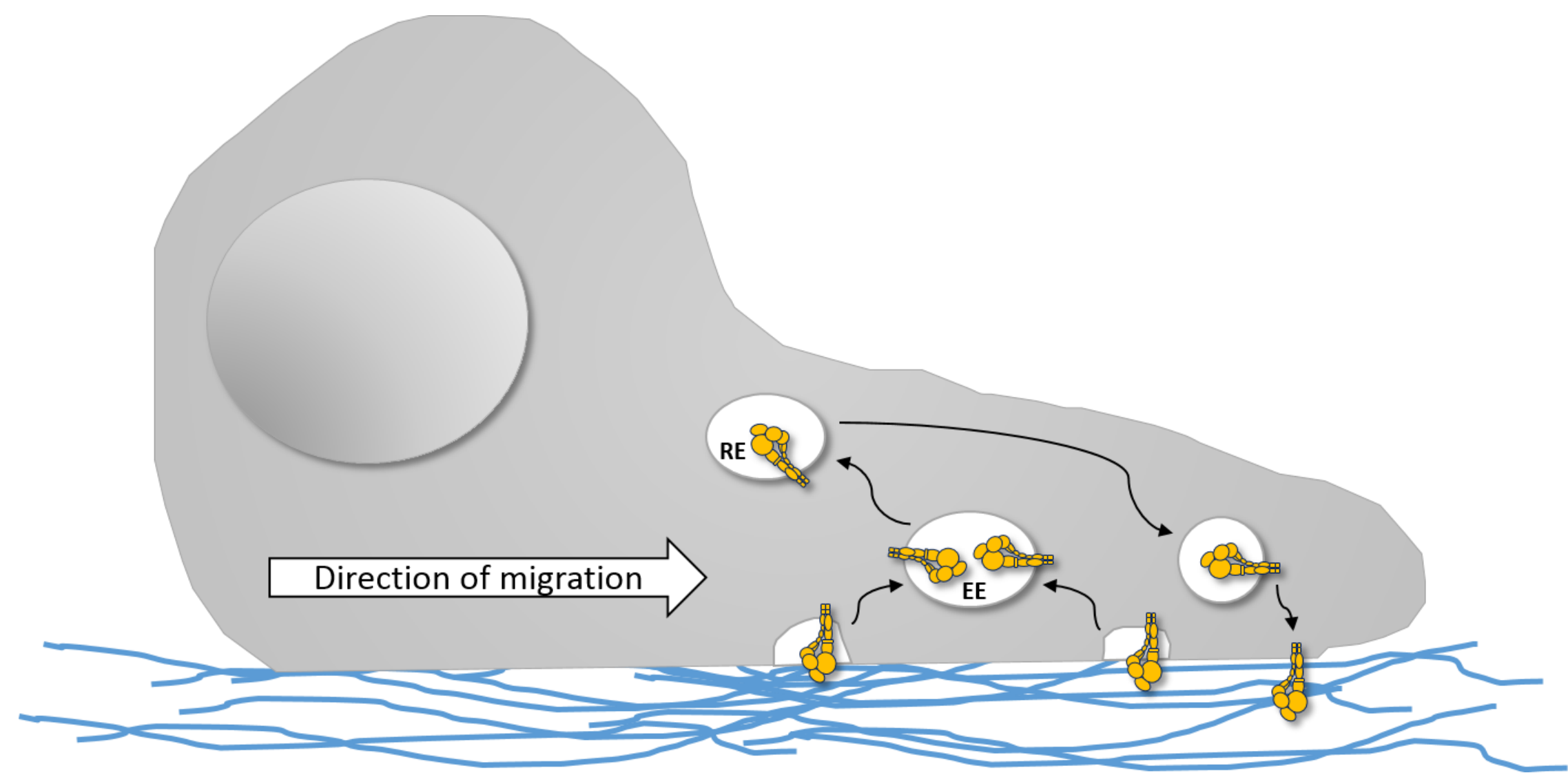

Figure 5 Cellular migration requires coordinated regulation of adhesion molecules at the cell surface. Adhesion molecules forming focal contacts are internalized and recycled to be deposited at the leading edge of the cell. New focal contacts form in the protruding lamellipodia of migrating cells which the cell uses to generate locomotive force, and finally as the cell moves past the sites of focal adhesion, these are disassembled and the parts recycled. 


\section{Integrins}

Integrins are cell adhesion receptors on the cell surface that facilitate coupling of the extracellular matrix (ECM) to the cytoskeleton. Integrins are heterodimeric, transmembrane glycoproteins (Felding-Habermann, 2003). An integrin heterodimer (Figure 6) has one $\alpha$-subunit non-covalently linked to one $\beta$-subunit (Felding-Habermann, 2003). Each subunit contains a single membrane spanning helix and a short unstructured cytoplasmic tail (Campbell \& Humphries, 2011). The $\alpha$ - and $\beta$ - subunits are constructed from several domains with flexible linkers between them (Campbell \& Humphries, 2011). $\alpha$-subunits have approximately 1000 amino acids and $\beta$-subunits have approximately 750 amino acids (Desgrosellier \& Cheresh, 2010). There are $18 \alpha$-subunits and $8 \beta$-subunits in mammals that make at least $24 \alpha \beta$ heterodimers (Desgrosellier \& Cheresh, 2010).

The profile of integrin heterodimers on a certain cell`s surface dictates the extent to which it will adhere to and migrate on different surfaces (Table 1) (Desgrosellier \& Cheresh, 2010). Integrins recognize specific adhesive sequences and bind directly to ECM components such as fibronectin, fibrinogen, osteopontin, vitronectin, collagen, and laminin (Desgrosellier \& Cheresh, 2010). For example, $\alpha$ v integrins and $\alpha 5 \beta 1$ recognize the RGD sequence on their ligands (Desgrosellier \& Cheresh, 2010). Other adhesive sequences are EILDV and REDV sequences (Desgrosellier \& Cheresh, 2010). Binding to the ECM and cytoskeletal components such as actin, talin, and kindlin provides necessary traction for cell motility and invasion (Desgrosellier \& Cheresh, 2010). 


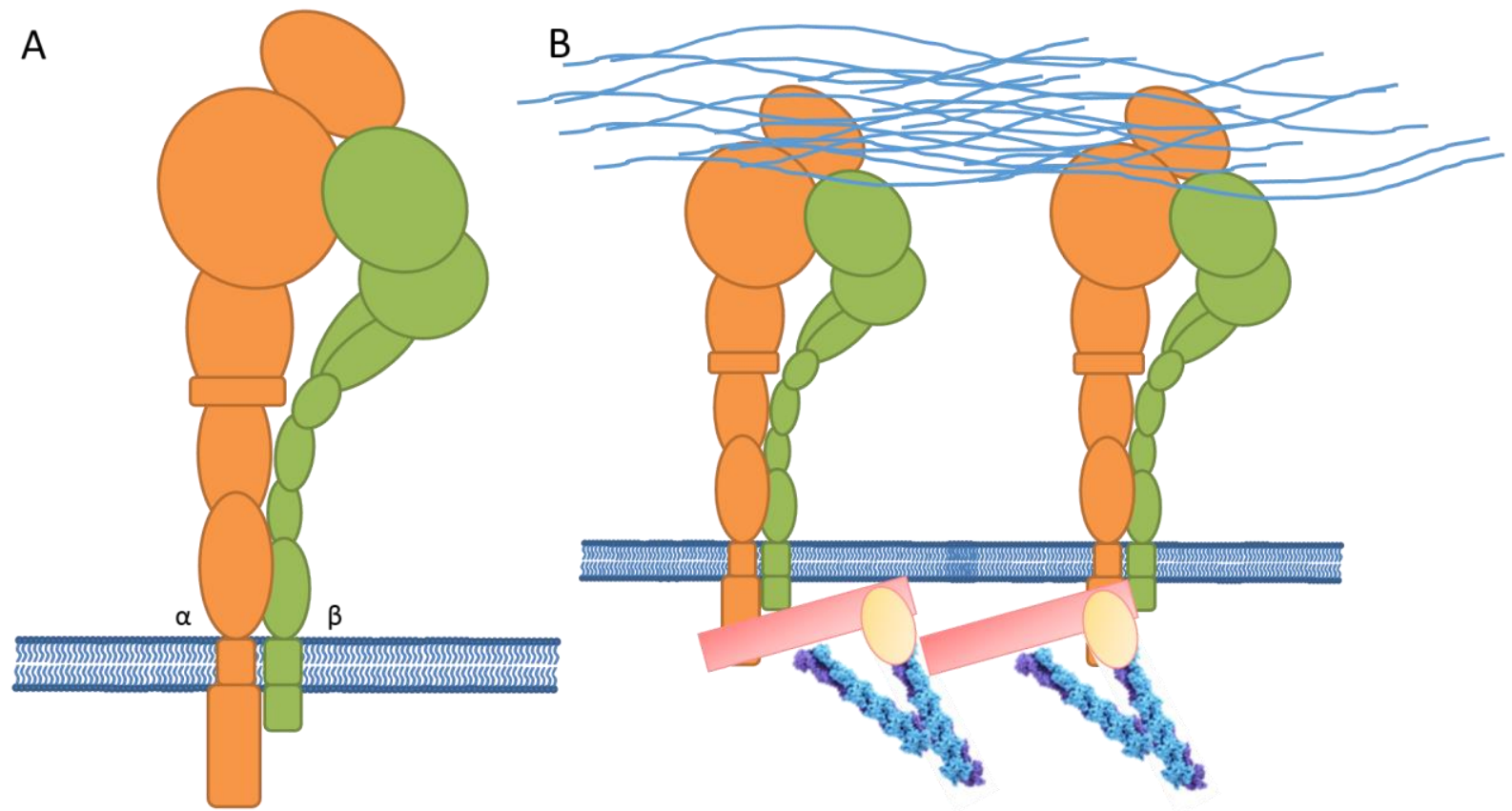

Figure 6 A) An integrin heterodimer has one $\alpha$-subunit and one $\beta$-subunit non-covalently linked together. Each subunit contains a single membrane spanning helix and a short unstructured cytoplasmic tail. The $\alpha$ - and $\beta$ - subunits are constructed from several domains with flexible linkers between them. B) Integrin heterodimers bind extracellular matrix proteins with their extracellular domains and bind cytoskeletal proteins such as talin, kindlin, and actin (pictured in red, light orange and blue, respectively) with their intracellular domains to form focal contacts.

Table 1 Examples of integrin heterodimers and their ligands

\begin{tabular}{|lll|}
\hline Name & Distribution & Ligands \\
\hline $\boldsymbol{\alpha}_{\mathbf{1}} \boldsymbol{\beta}_{\mathbf{1}}$ & Many & Collagens, laminins \\
\hline $\boldsymbol{\alpha}_{\mathbf{7}} \boldsymbol{\beta}_{\mathbf{1}}$ & Muscle, glioma & laminins \\
\hline $\boldsymbol{\alpha}_{\mathbf{v}} \boldsymbol{\beta}_{\mathbf{1}}$ & Ocular melanoma; neurological tumours & Vitronectin; fibrinogen \\
\hline $\boldsymbol{\alpha}_{\mathbf{v}} \boldsymbol{\beta}_{\mathbf{3}}$ & Activated endothelial cells, melanoma, glioblastoma & $\begin{array}{l}\text { Vitronectin, fibronectin, } \\
\text { fibrinogen, osteopontin }\end{array}$ \\
$\boldsymbol{\alpha}_{\mathbf{v}} \boldsymbol{\beta}_{\mathbf{5}}$ & Fibroblasts, epithelial cells, \& more & Vitronectin and adenovirus \\
\hline $\boldsymbol{\alpha}_{\mathbf{6}} \boldsymbol{\beta}_{\mathbf{4}}$ & Epithelial cells & laminin \\
\hline
\end{tabular}


$\beta 1$-integrin is the principle binding partner of many $\alpha$-integrins (Table 1) and as such is a key adhesion molecule (Desgrosellier \& Cheresh, 2010). Although many integrin complexes contain $\beta 1$-integrin, there exist differences in ECM binding between them. For example, integrin $\alpha 1 \beta 1$ binds collagen and laminin, $\alpha 4 \beta 1$ binds fibronectin and VCAM1, $\alpha 5 \beta 1$ binds fibronectin and L1-CAM, $\alpha 6 \beta 1$ binds laminin, merosin, and kalinin (Avraamides, Garmy-Susini, \& Varner, 2008) an $\alpha v \beta 1$ binds vitronectin and fibrinogen (J. F. Marshall et al., 1995). Differential expression of $\beta 1$-containing integrin complexes in various cell types or tissues (Table 1) may specify particular adhesion and migration properties but distinct $\beta 1$-integrin heterodimers may share some aspects of regulation that depend on $\beta 1$-integrin.

Integrin ligation to the ECM results in a clustering of integrins in the plane of the plasma membrane (PM) which recruits various signalling and adaptor proteins to form focal adhesions (Desgrosellier \& Cheresh, 2010). Focal adhesions are dynamic macromolecular complexes that link the ECM to the actin cytoskeleton through integrins (Desgrosellier \& Cheresh, 2010). Although integrins lack kinase activity, their clustering recruits and activates kinases, such as focal adhesion kinases (FAKs) and Src family kinases (SFKs), and scaffolding molecules such as P130 CRK-associated substrate (p130CAS). Integrin clustering in focal adhesions involves cytoskeletal reorganization and therefore can lead to changes in cell shape (Felding-Habermann, 2003).

\section{Endocytosis and recycling of integrins}

Integrins are internalized by clathrin-dependent and clathrin-independent endocytic mechanisms (P. T. Caswell, Vadrevu, \& Norman, 2009). A given integrin heterodimer can 
follow more than one internalization route (P. T. Caswell et al., 2009). Clathrin adaptors for clathrin-mediated endocytosis that are involved in the clathrin-mediated internalization of integrins include HCLS1-associated protein X1 (HAX1), disabled (Dab), and Numb (P. T. Caswell et al., 2009). Most recently, the clathrin adaptor protein Dab2 was shown to recruit certain $\beta 1$-integrins to Dab2-rich clathrin coated pits (CCPs) across the cell surface and that their endocytosis is Dab2 dependent (Teckchandani et al., 2009). Upon internalization, integrin heterodimers localize to early endosomes from which they can be either returned directly to the PM in a Rab4 dependent manner or further trafficked to the perinuclear recycling compartment (PNRC) before recycling through Rab11- and/or Arf6-dependent mechanisms (P. Caswell \& Norman, 2008; M. C. Jones et al., 2006; Mai et al., 2011; Pellinen et al., 2006). The journey of internalized $\beta 1$-integrins through the endomembrane system is shown in Figure 7. $\beta 1$-integrins localize to Rab21-positive early endosomes where they are retained by their interaction with Rab21 (Mai et al., 2011; Pellinen et al., 2006). P120RasGAP displaces the Rab21-integrin interaction allowing for $\beta 1$-integrin exit from Rab21-endosomes (Mai et al., 2011). $\beta 1$-integrins are returned to the PM by Rab11-positive recycling endosomes (Mai et al., 2011; Pellinen et al., 2006).

\section{Integrins in proliferation and angiogenesis}

Integrins have been shown to exhibit cellular functions other than those involved in cellular adhesion. For example, integrins can regulate proliferation (Assoian \& Klein, 2008) and, when ligated, can enhance cell survival through several mechanisms including by activation of the PI3K-Akt pathway (Aoudjit \& Vuori, 2001). The $\beta 1$ class of integrins have been shown to be required for angiogenesis - the formation of new blood vessels (Bloch et al., 1997). 
Angiogenesis is highly important throughout processes such as embryonic development, tissue repair, and fertility, but also a key step in chronic inflammation, tumour growth and tumour metastasis (Avraamides et al., 2008). New blood vessels in tumours can grow by sprouting from pre-existing vessels to provide blood flow to support a growing tumour or to a location where the metastasized tumour cells colonize. $\beta 1$-integrin-null embryos die by embryonic day 9.5-10.5 in utero due to defects in implantation (Fassler \& Meyer, 1995; Stephens et al., 1995) and animals with endothelial cell-specific deletion of $\beta 1$-integrin die by embryonic day 10.5 with severe vascular defects (Tanjore, Zeisberg, Gerami-Naini, \& Kalluri, 2008). Furthermore, endothelial cell proliferation and vessel branching is absent in $\beta 1$-integrinnull embryoid bodies (Bloch et al., 1997). The $\beta 1$-integrin family has a clear, crucial role in angiogenesis.

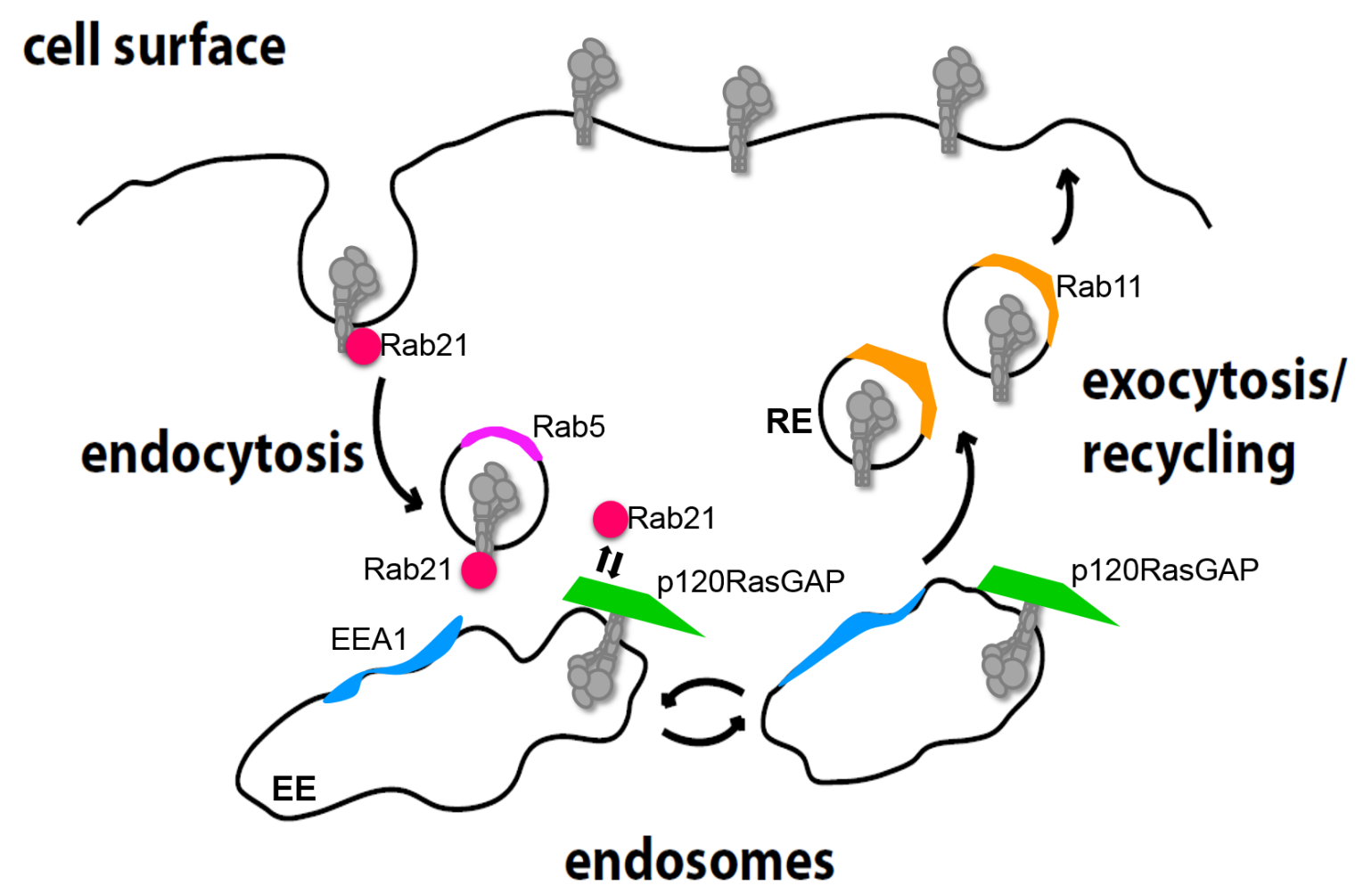

Figure 7 Integrin heterodimers containing $\beta 1$-integrin are recycled in a Rab21/ p120RasGAP/Rab11-dependent manner (Figure adapted from Mai et al., 2011). 


\section{Integrin signalling}

Since integrins are expressed uniquely on different cell types, they maintain the integrity of organs and tissues by preventing cell survival in improper environments (Desgrosellier \& Cheresh, 2010). Integrins are also known to be highly implicated in intracellular signalling and can perform "inside-out" signalling as well as "outside-in" signalling (Desgrosellier \& Cheresh, 2010). "Inside-out" signalling describes when integrin function is controlled from within the cell. For example, association of the $\beta$-integrin cytoplasmic tail with FERM domain-containing proteins such as talin and kindlin switches the integrin heterodimer from a low-affinity conformation to a high-affinity active conformation (Harburger, Bouaouina, \& Calderwood, 2009; Wegener et al., 2007). "Outside-in" signalling initiated by integrins involves recruiting signalling moieties (such as focal adhesion kinase) that provide signals to the migratory and proliferative machinery of the cell (P. T. Caswell et al., 2009).

\section{Systemic analysis of cell surface proteome}

There are hundreds to thousands of proteins at the cell surface. The cell-surface proteome holds a wide diversity of proteins that contribute to numerous cellular processes. Experimental approaches that are hypothesis-driven about specific proteins are limited and do not allow for a systemic "snapshot" of how the cell-surface proteome is regulated by a specific stimulus.

Some previous studies have successfully purified the cell-surface proteome and quantified changes in cell surface proteins in response to changing stimuli or environments. For example, Rugg-Gunn and partners used cell-surface protein biotinylation to isolate membrane proteins and 
found changes in the cell-surface proteome upon differentiation of stem cells (Rugg-Gunn et al., 2012).

In a study of the cell-surface proteome in human mesenchymal stem cells in response to the growth factor, bFGF, Lee and associates (2013) used functional Gene Ontology (GO) analyses to identify functional protein groups or clusters that undergo regulation (Lee et al., 2013). GO includes three structured, controlled vocabularies that describe gene products in terms of their associated molecular functions, cellular components, and biological processes (D. W. Huang, Sherman, \& Lempicki, 2009). GO analyses allow for an understanding of the biological meaning and relevance of the results of a cell-surface proteome isolation and identification (D. W. Huang et al., 2009). Isolation of the cell-surface proteome coupled with quantitative analysis of changes of certain functional groups as denoted by GO allows for a systematic and biologically relevant understanding of how an entire cell compartment may react and adapt to changing conditions. 


\section{Rationale and hypothesis}

AMPK is emerging as a key regulator of cell physiology by allowing cell survival and homeostasis under conditions of energy stress. A response to energy stress is likely to involve a coordinated remodeling of cell surface proteins that would effect a reduction in energy expenditure and increased energy intake. Which cell surface proteins AMPK may regulate as well as the mechanism by which AMPK may control cell surface membrane traffic are poorly understood. Elucidating the regulation by AMPK of the cell surface proteome may allow for a better understanding of how the cell responds to metabolic stress and may lead to improved characterization of human cancers and diseases allowing for the discovery of potential treatment avenues.

I hypothesize that the cell surface proteome is significantly altered during metabolic stress through the activation of AMPK. Using mass spectrometry, I determined how AMPK activation regulates the cell surface proteome. Of the several groups of proteins regulated at the cell surface by AMPK, I identified cell adhesion and cell migration molecules as key targets of AMPK regulation. I examined the mechanism of regulation of adhesion molecule membrane traffic by AMPK and found that $\beta 1$-integrin abundance is depleted at the cell surface following AMPK activation. This effect is not seen with transferrin receptor and appears to be related to the changed recruitment of Dab2 to CCPs upon AMPK activation. Therefore AMPK regulates the cell surface proteome in response to metabolic stress potentially through the regulation of Dab2 dependent CME of specific cargoes. 


\section{Materials and Methods}

\section{RPE Cell Culture and AMPK Activation}

Human non-immortalized, non-transformed Retinal Pigment Epithelial (AREP-19) cells were obtained from ATCC (henceforth RPE cells). Populations of RPE cells stably expressing clathrin light chain a fused to enhanced green fluorescent protein (RPE -GFP-CLCa) or to red fluorescent protein (RPE -RFP-CLCa) were previously generated (Aguet, Antonescu, Mettlen, Schmid, \& Danuser, 2013). All RPE cells were maintained in 10cm culture dishes in DMEM F12 supplemented with 10\% fetal bovine serum (FBS) and 5\% streptomycin/penicillin in a humidified incubator at $37^{\circ} \mathrm{C}$ and $5 \% \mathrm{CO}_{2}$. For experiments requiring AMPK activation, RPEGFP-CLCa- were washed with PBS and then cultured in DMEM F12 supplemented with $0.1 \%$ FBS and 100 $\mu \mathrm{M}$ A-769662 purchased from Abcam (Cambridge, MA) or 2 mM AICAR purchased from Cell Signaling Technology (Danvers, MA). After treatment for 10, 20, 30, 60, or 90 minutes, the cells were washed with PBS and harvested.

\section{cDNA transfection}

The engineering and validation of a mCherry-Dab2 expression cDNA construct was previously described (Mettlen et al., 2010). Transfection of RPE cells with Dab2-mCherry cDNA or mCherry only cDNA (control) was performed using FuGene HD transfection reagent (Promega, Madison, WI) as per the manufacturer's instructions. Briefly, RPE-GFP-CLCa cells were transfected using $1.1 \mu \mathrm{g}$ DNA and $3.3 \mu \mathrm{L}$ FuGene $\mathrm{HD}$ reagent in a total volume of $1 \mathrm{~mL}$ (per well of a six-well plate) for 4 hours. 


\section{Cell Surface Protein Labelling and Purification}

In order to selectively and covalently modify cell-surface proteins with a biotin moiety, cells were ectopically labelled with $0.5 \mathrm{mg} / \mathrm{mL}$ Sulfo-NHS-SS-biotin (Figure 8) in PBS for 30 minutes at $16^{\circ} \mathrm{C}$ and then quenched with 50mM Tris- $\mathrm{HCl}$ (Bioshop, Burlington, ON) for 10 minutes at $16^{\circ} \mathrm{C}$. Cells were then homogenized in modified RIPA buffer (50mM Tris-Cl pH 7.4; 0.25\% Na deoxycholate; $150 \mathrm{mM} \mathrm{NaCl}, 1 \mathrm{mM}$ EDTA; 50mM n-octylglucoside) supplemented with protease inhibitors. Homogenized cells were incubated under constant rotation at $4{ }^{\circ} \mathrm{C}$ for 2 hours and then centrifuged at $13000 \mathrm{rpm}$ for 15 minutes. After centrifugation, the pellet was discarded and the protein concentration was measured. Equal amounts of protein were incubated under constant rotation with streptavidin-conjugated sepharose beads overnight at $4{ }^{\circ} \mathrm{C}$.

Intracellular proteins were collected in the supernatant and after rigorous RIPA washes, cellsurface proteins were eluted with 100mM DTT (Bioshop, Burlington, ON).

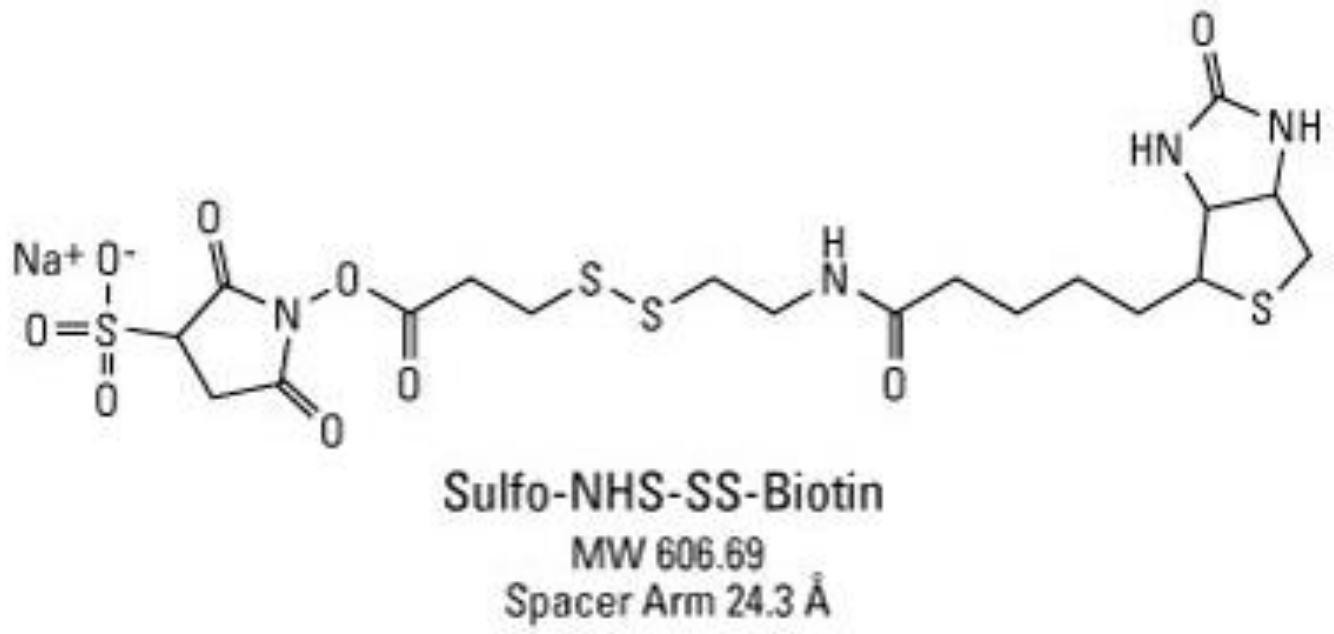

Figure 8 Sulfo-NHS-SS-Biotin was purchased from Pierce and used to ectopically label cell surface proteins. The sulfonate group on the NHS gives the reagent a negative charge which prevents permeability of the PM, thus allowing labelling of cell surface proteins. The NHS group reacts with exposed primary amines and forms a stable amide conjugate. The long spacer arm on this reagent prevents stearic hindrance but also contains a disulphide bond which can be easily cleaved using a reducing reagent such as DTT 


\section{Trypsin Digest of Cell Surface Proteins, Zip-Tip Preparation, LC-ESI-MS/MS, and Protein Pathway Analysis}

Cell-surface proteins were incubated with digestion buffer (1M Tris; 2M Urea; 50\% Acetonitrile; $\mathrm{pH} 8.8$ ) and $1 \mu \mathrm{L}$ trypsin (Roche, Indianapolis, IN) at $37^{\circ} \mathrm{C}$ overnight. Samples were incubated in $2 \mathrm{mM}$ DTT for $1 \mathrm{~h}$ at $50^{\circ} \mathrm{C}$. After brought to room temperature, samples were incubated with $1 \mu \mathrm{L}$ of trypsin (Roche, Indianapolis, IN) for $1 \mathrm{~h}$ at $37^{\circ} \mathrm{C}$ followed by $5 \%$ formic acid solution. LC-ESI-MS/MS analysis was performed after solid-phase extraction of peptides using Zip-Tip ${ }^{\circledR}$ C18 (EMD Millipore, Billerica, MA) stationary phase for small-scale sample cleanup.

LC-ESI-MS/MS data for charge states 1,2, 3, with a minimum peptide length of 4 were run against 4 search engine algorithms (Sequest, Tandem, Mascot, and Omssa) set for maximum 2 missed cleavages to identify proteins. All proteins present in background samples were subtracted from the total list of results. I found the ratio of proteins found in control samples to proteins found in samples treated with the AMPK-activator, A-769662, and set the following cut-offs: Control/AMPK-activated total protein identifications $\geq 2=$ Proteins depleted at the cell surface after AMPK-activation; Control/AMPK-activated total protein identifications $\leq 0.5=$ Proteins enriched at the cell surface after AMPK-activation. GO annotation and clustering of the identified proteins was obtained for each category (Proteins depleted vs enriched at the cell surface after AMPK-activation) using DAVID bioinformatics resources (version 6.7) see http://david.abcc.ncifcrf.gov/summary.jsp (D. W. Huang et al., 2009). 


\section{Immunofluorescence}

To detect cell-surface proteins, intact cells were washed in PBS supplemented with $1 \mathrm{mM}$ $\mathrm{CaCl}_{2}$ and $1 \mathrm{mM} \mathrm{MgCl}$ (PBS+) and blocked for 15 minutes on ice in a solution of PBS+ containing 3\% BSA before primary antibody to an ectopic epitope (recognizing Transferrin receptor, CD71, from Santa Cruz Biotechnologies, Santa Cruz, CA or $\beta 1$-integrin from EMD Millipore, Darmstadt, Germany) was added for $1 \mathrm{~h}$ at $4^{\circ} \mathrm{C}$. Coverslips were washed in PBS+ before fixing in a solution of PBS+ containing 4\% PFA for 30 minutes at room temperature. After quenching with a solution of PBS+ containing 100mM Glycine and washing with PBS, cells were blocked with a PBS solution containing 3\% BSA for 15 minutes and secondary antibodies were added to the coverslips for 1 hour at room temperature. Secondary antibody used was goat anti-mouse cy3.

To visualize total (cell-surface and intracellular) protein content, cells were fixed in a PBS solution containing 4\% PFA for 30 minutes at room temperature, quenched with a PBS solution containing $100 \mathrm{mM}$ glycine, and permeabilized with $0.1 \%$ Triton X-100 in PBS and 100mM glycine for 10 minutes at room temperature. Cells were washed in PBS and blocked in a PBS solution containing 3\% BSA for 20 minutes at room temperature before primary antibody was added for 1 hour at room temperature. Coverslips were rinsed in PBS before the addition of secondary antibodies for $1 \mathrm{~h}$ at room temperature. After several PBS washes, coverslips were mounted in Dako fluorescent mounting media (Dako, Carpinteria, CA). Secondary antibody used was goat anti-mouse cy3. 


\section{Epifluorescence Imaging}

Fixed cells on $22 \mathrm{~mm}$ by $22 \mathrm{~mm}$ coverslips mounted on glass slides using Dako fluorescent mounting media (Dako, Carpinteria, CA) were visualized using a 63x/numerical aperture 1.49 oil objective on a Leica DM5000 B epifluorescence microscope (Leica Microsystems, Wetzlar, Germany) with a X-Cite 120 fluorescence illumination system light source (Lumen Dynamics Group, Missassauga, ON). Images were recorded using fixed camera settings (LEICA CTR 5000, Leica Microsystems, Wetzlar, Germany). Images were acquired using Adobe Photoshop (San Jose, CA) and all exposure times and image scaling were equal within an experiment.

\section{Quantification of cell surface staining and total staining intensity}

Surface $\beta 1$-integrin or TfR or total $\beta 1$-integrin in each cell was quantified using ImageJ software (National Institutes of Health). Regions of interest corresponding to entire cells were overlaid onto micrographs in ImageJ (National Institutes of Health) and mean intensity of fluorescence was measured and average background intensity was subtracted from these means. Images were 16-bit and typical intensity ranges were between 10-30000 units ensuring pixel intensity saturation did not occur.

Measurements of $\beta 1$-integrin cell surface abundance under three conditions (Control, AICAR, A-769662) were subject to one-way analysis of variance (ANOVA) with NewmanKeuls post test, with $\mathrm{p}<0.05$ as a threshold for significant difference among conditions. Measurements of TfR cell surface abundance under two conditions (Control, A-769662) were subject to a Student's t-test, with $\mathrm{p}<0.05$ as a threshold for significant difference among conditions. 


\section{TIRF Microscopy Imaging and analysis}

Fixed cells on $22 \mathrm{~mm}$ by $22 \mathrm{~mm}$ coverslips were mounted on two double-strips of doublesided tape on a glass slide and sealed with VALAP (Antonescu et al., 2011). The cells were visualized using a 60x/numerical aperture 1.49 oil objective on an Olympus IX81 microscope (Olympus, Tokyo, Japan) equipped with individual CellTIRF modules illuminated with lasers of wavelengths $491 \mathrm{~nm}$ and $561 \mathrm{~nm}$ and emission filters of $520 \mathrm{~nm} \pm 35 \mathrm{~nm}$ and $624 \mathrm{~nm} \pm 40 \mathrm{~nm}$. Images were recorded using fixed camera settings (C9100-13 EM-CCD, Hamamatsu). Images were acquired using Volocity (PerkinElmer, Waltham, MA) and all exposure times and image scaling were equal within an experiment.

CCPs are diffraction limited objects whose light patterns are approximated by a pointspread function. I detected CCPs using a Gaussian model approach as per Aguet et al 2013 to identify the position of CCPs and the intensity of GFP-LCa and of mCherry-Dab2 fluorescence at each identified CCP (Aguet et al., 2013).

\section{Western Blotting}

Lysates from whole-cell extracts, cell-surface proteins, or intracellular proteins were subjected to gel electrophoresis. Proteins were then transferred to PVDF membranes (Bio-Rad, Burlington, ON). The membranes were blocked in a solution of TBS-T containing 4\% BSA or $3 \%$ milk for 30 minutes at room temperature and then incubated at room temperature with the primary antibody for $1 \mathrm{~h}$. Rabbit anti-CD71 (1:1000), rabbit anti-Glut1 (1:1000), and rabbit antiEGFR (1:1000) were purchased from GeneTex (Irvine, CA), goat anti-EGFR, mouse anti-TfR (1:400, 1:1000), and mouse anti-CHC (1:1000) were purchased from Santa Cruz Biotechnology 
(Santa Cruz, CA). Rabbit anti- $\beta 1$ integrin (1:1000), rabbit anti-pAMPK (1:500), rabbit antipACC (1:500), rabbit anti-pan-actin (1:1000), and rabbit anti-total ERK (1:1000) were purchased from Cell Signaling Technology (Danvers, MA). Mouse anti- $\beta 1$-integrin (1:400) was purchased from Calbiochem (Billerica, MA). Secondary antibodies were goat anti-rabbit, goat anti-mouse, (Jackson Immunoresearch, West Grove, PA). Streptavidin-POD (1:1000) was purchased from Roche. 


\section{Results}

Systematic analysis of the regulation of abundance of proteins requires a method for purifying cell surface proteins. I established this methodology using limited biotinylation of cell surface proteins. Subsequently, to study how AMPK regulates cell surface membrane traffic, I sought to optimize conditions for AMPK activation. Following this, I combined these methods to isolate cell surface proteins from control and AMPK-activated cells. These samples were subjected to mass spectrometry analysis, allowing identification of cell surface proteins in control and AMPK-activated cells. The proteins identified by this method were then subjected to Gene Ontology (GO) clustering to identify cellular processes involving cell surface proteins that are regulated by AMPK activation. This approach is described below.

\section{Results Part 1: Regulation of the cell-surface proteome by AMPK}

\section{Validation and optimization of cell-surface protein purification assay}

In order to determine regulatory effects of metabolic stress on the cell surface proteome, I developed an assay to selectively purify cell surface proteins. I labeled cell surface proteins using Sulfo-NHS-SS-Biotin ( $5 \mathrm{mg} / \mathrm{mL}$; Pierce) at $16^{\circ} \mathrm{C}$ for 30 minutes (Figure 8). The sulfonate group on the NHS gives the reagent a negative charge which confers cell impermeability, thus allowing for labelling of cell surface proteins exclusively. The NHS group on the reagent reacts with exposed primary amines and forms a stable amide conjugate. The long spacer arm on this reagent prevents stearic hindrance but also contains a disulphide bond which can be easily cleaved using a reducing reagent such as DTT. After incubation of biotinylated cells with streptavidin labeled 
sepharose beads, I eluted the biotinylated proteins with 50mM DTT and performed SDS-PAGE followed by silverstain. When cells were not labeled with the biotinylation reagent, few to no proteins were eluted from the streptavidin beads (Figure 9, left lane) whereas when the cells were labeled with the biotinylation reagent, many proteins were eluted (Figure 9, 2 right lanes). Hence, this biotinylation assay successfully and cleanly (i.e. with little background non-specific binding of unbiotinyalted proteins to beads) extracts proteins from RPE cells; whether this assay is selective for cell surface proteins or whether the reagent was off-target labelling cytosolic proteins remained to be determined.

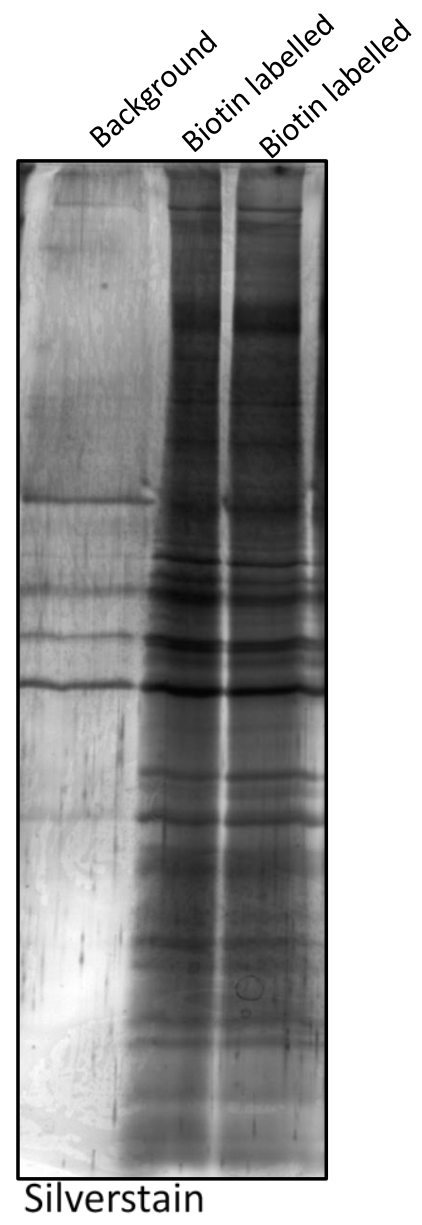

Figure 9 Silverstain gel image of cells either unlabelled (Background) or labelled with Sulfo-NHS-SS-biotin (Biotin labelled) and subjected to purification using streptavidinconjugated sepharose beads. The silverstain only detected proteins from samples of cells labelled with Sulfo-NHS-SS-Biotin. Therefore, only biotinylated proteins can be purified with these beads. 
I next sought to confirm that the purification assay selectively labels cell surface proteins with an exofacial biotin attachment. To ensure that the purification assay selectively labels and isolates cell surface proteins rather than intracellular proteins, I performed SDS-PAGE with extracts from my assays and performed a Western blot with antibodies specific to integral membrane proteins or intracellular proteins which will act as markers for these types of proteins (Figure 10). The integral membrane protein EGFR which has an exofacial domain of 588 amino acids harboring 35 lysine resides was successfully extracted from cells and found in the pulldown fraction. Erk and actin are cytosolic proteins that are known to interact highly with cellsurface proteins (Burridge et al., 1990; DeMali, Wennerberg, \& Burridge, 2003; Kang \& Banfield, 2010), therefore I expected to see some detection of these proteins in the pull-down fraction.

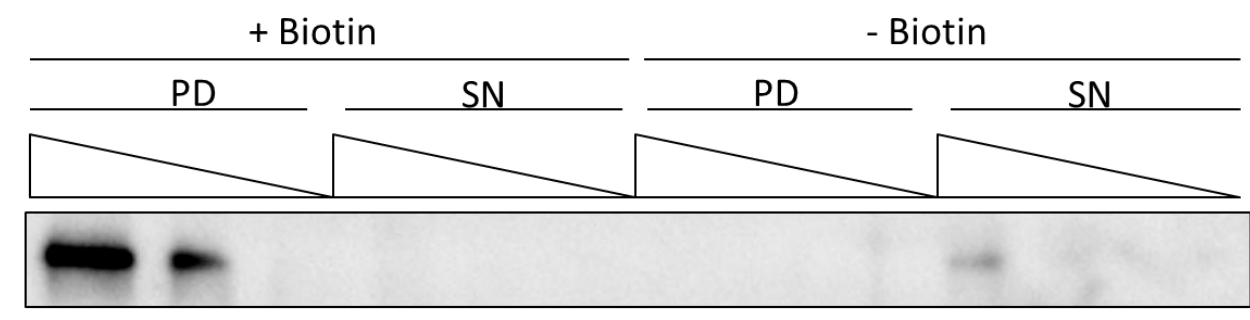

$\alpha-E G F R$

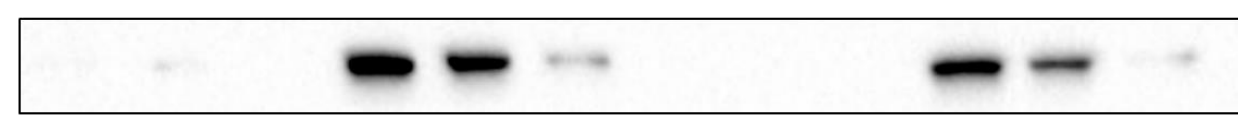

$\alpha-\mathrm{CHC}$

B

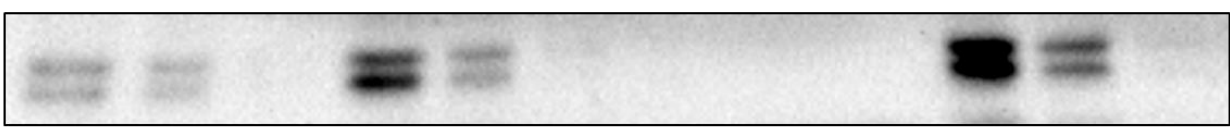

$\alpha$-ERK

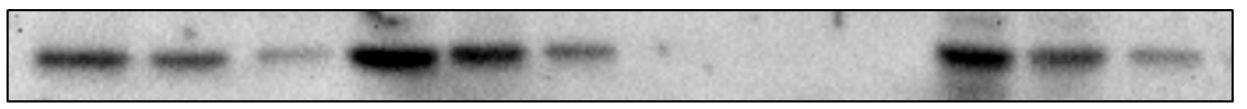

$\alpha$-actin

Figure 10 Western blot images showing clean purification of cell surface proteins with little cytosolic content. Pull-down (PD) and Supernatant (SN) fractions were loaded in decreasing concentrations (left to right). A) EGFR is an integral membrane protein that is found in the PD fraction of biotinylated cells suggesting effective selective cell-surface protein purification. B) Cytosolic protein, clathrin heavy chain (CHC), is found predominantly in the $\mathrm{SN}$ fraction of both biotinylated and unlabeled cells. Cytosolic, but highly membrane protein-interacting, proteins Erk and actin were detected primarily in the SN fraction with some low-level detection in the PD fractions. No proteins were detected in the PD fraction when cells were not biotinylated. 
$\mathrm{CHC}$ is the best candidate for a cytosolic protein because it has no direct contacts with integral membrane proteins and can only form low affinity interactions with membraneassociated complexes. Furthermore, of the 1675 amino acid residues in CHC, 94 are lysines so I would expect $\mathrm{CHC}$ to be heavily biotinylated if the reagent was permeable to the cell surface.

Intracellular proteins $\mathrm{CHC}$, Erk, and actin were found primarily in the supernatant fraction, with Erk and actin appearing faintly in the pull-down fraction as well. When I did not biotinylate cells, EGFR, CLC, Erk, and actin were all found exclusively in the supernatant fraction. The purification assay that I developed successfully selectively labels and extracts cell-surface proteins and intracellular proteins can be retrieved from the supernatant fraction. This assay uses a reducing reagent, DTT, to elute the proteins from the beads. Whether the elution of protein was specific to a reducing environment or not was necessary to next elucidate.

I tested several different elution conditions to determine the ideal conditions for maximal recovery of biotinylated proteins without also recovering proteins that may have stable, nonspecific associations with the beads (Figure 11). I designed the biotinylation and purification assay so that the only way to elute biotinylated cell-surface proteins from the streptavidin labelled beads is to introduce a reducing environment to cleave the disulphide bond contained within the sulfo-NHS-SS-biotin reagent. High salt concentrations can interrupt electrostatic interactions between proteins and beads. I do not expect to see proteins eluted by high salt concentration in the cell-surface purification assay because the beads used were highly specific to bind biotinylated proteins. A high concentration of free biotin may be expected to elute cell surface proteins from streptavidin labeled beads by outcompeting and displacing current biotinstreptavidin linkages. Biotin and streptavidin bind with such high affinity and their off-rate is so low, however, that this method of elution is extremely unlikely to successfully elute biotinylated 
cell-surface proteins. Only when I used DTT to elute the proteins were there any proteins labelled on the silverstain gel, an analysis method used to detect any protein even in very low concentrations. RIPA buffer and LSB were both suitable solvents for this assay when combined with the reducing reagent DTT. High salt and high free biotin concentrations were not successful in eluting the proteins from the beads, as expected. Elution of proteins from streptavidin labelled sepharose beads was only successful in the presence of a reducing reagent such as DTT.

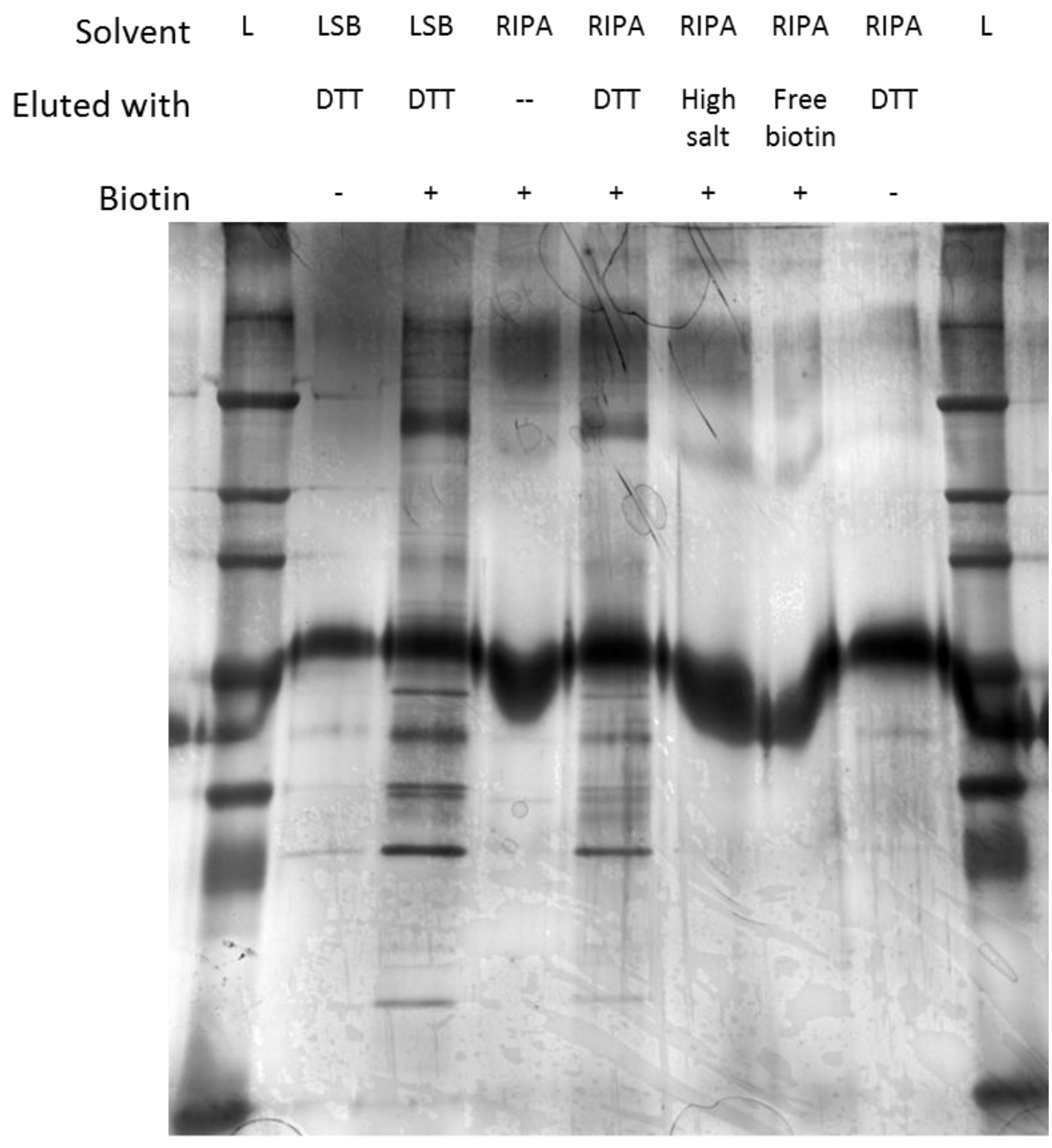

Figure 11 Three different eluting agents were tested to determine the ideal conditions for maximal elution of biotinylated proteins with as little contamination as possible. Only DTT was successful in eluting biotinylated proteins from streptavidin conjugated sepharose beads. Neither high concentration of salt nor an excess of free biotin were successful in eluting the biotinylated proteins. 
AMPK is activated by chemical analogues of AMP

AMPK is the metabolic stress sensor of the cell and biologically is activated upon AMP binding its gamma subunit displacing ATP. To study the effects of AMPK activation and not of other processes that also may be affected by increased levels of AMP in the cell, I sought to determine if AMPK can be experimentally activated with the AMP analogues AICAR and A769662 (Figure 12).

A
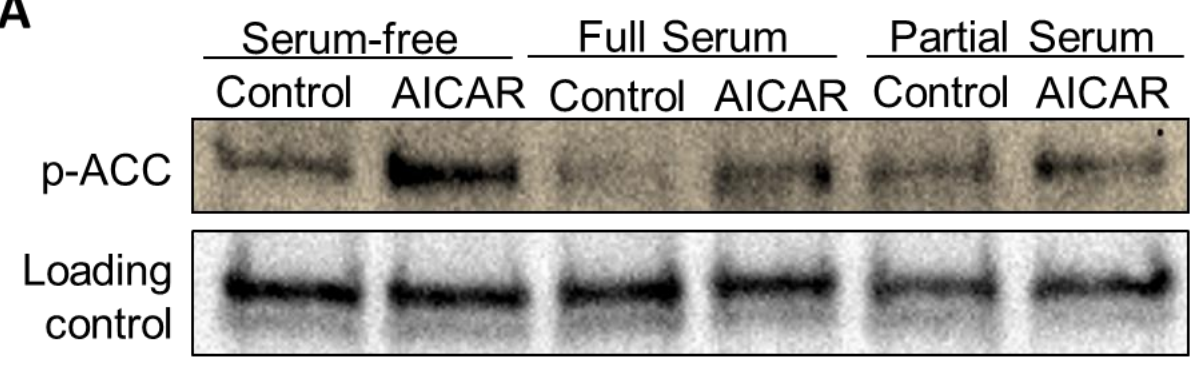

B

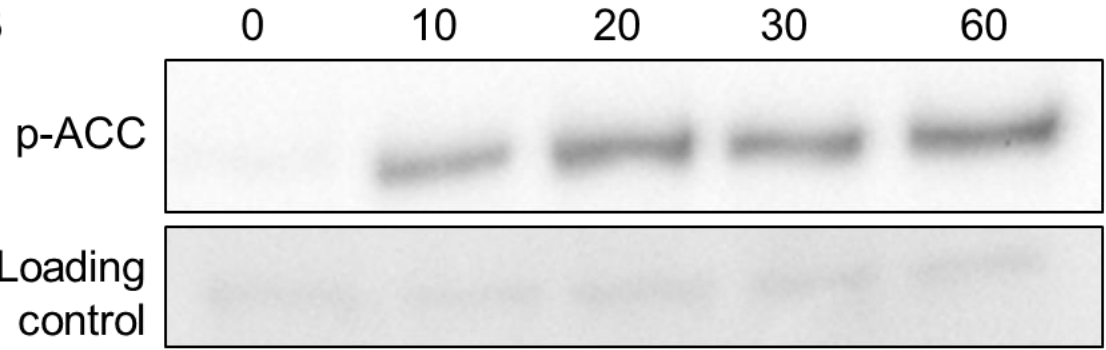

C

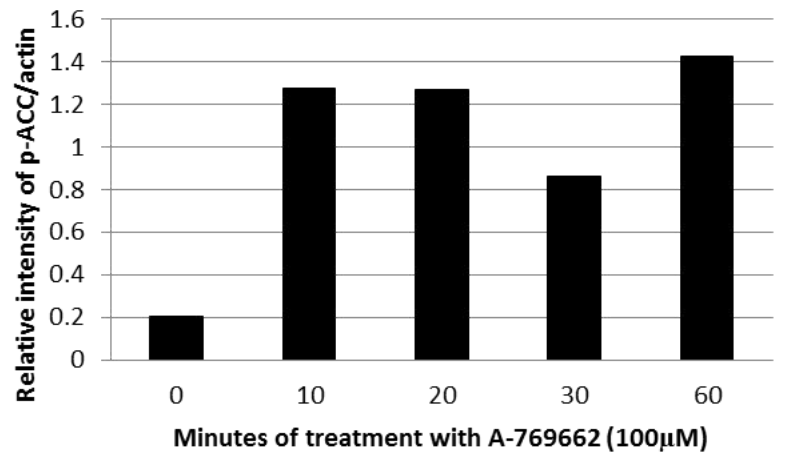

Figure $12 \mathrm{~A})$ A western blot for pACC shows the activation of AMPK in basal cells or cells treated with AICAR. Serum-free conditions lead to AMPK activation in untreated cells as expected in starvation conditions. AICAR treatment in full serum conditions lead to a repressed p-ACC signal. Partial serum AICAR treatment shows some p-ACC detection in control cells and a detectable increase in p-ACC after AICAR treatment. B) p-ACC detection over time with A-769662 treatment. AMPK is activated within 10 minutes of treatment and the p-ACC detection increases over time (quantification in $\mathrm{C}$ ). 
Serum starvation is used extensively in biochemical experiments because it allows for observation of acute responses and eliminates the possibility of the growth factors from the serum having an effect on the proteins or pathways of interest. Serum starvation would be helpful for studying the effect of AMPK activation because too much serum could inhibit AMPK. However, AMPK is activated in response to metabolic stress and the complete absence of serum may result in high basal AMPK activation, with little ability of added AMP analogues to further activate AMPK. Conceptually, a low serum concentration is the ideal condition enough serum to prevent high basal AMPK activation and not enough serum so that AMPK is inhibited.

To determine the best conditions for AMPK activation, I performed SDS-PAGE followed by a Western blot for p-ACC, an indirect measure of AMPK activation (Figure 12a). I performed the stimulation of cells with AICAR for 90 minutes in the absence of serum, with $10 \%$ serum, or with $0.1 \%$ serum. Basal activation of AMPK was highest when grown in serumfree media. Activation of AMPK was greater in full serum with AICAR stimulation compared to control. Partial serum was also an effective media solution for the experimental activation of AMPK (Figure 12a). I confirmed that low levels of serum would be ideal for future experiments focused on changes after AMPK activation.

I next sought to select a time point of AMPK activation for my cell-surface proteome analysis at which AMPK will have been active for a sufficient time to allow changes in cellsurface abundance of proteins to occur. To determine the time course of AMPK activation, I treated cells with A-769662 for 0, 10, 20, 30, or 60 minutes in partial serum and performed a western blot with an antibody recognizing p-ACC to measure AMPK activation indirectly (Figure 12b). AMPK activation reaches near maximum intensity after 10 minutes and remains 
relatively consistent over 60 minutes (Figure 12c). Since AMPK is activated as early as 10 minutes following A-769662 treatment, performing the cell-surface purification assay at 90 minutes after treatment allows 80 minutes for changes in cell surface abundance to manifest themselves.

\section{Regulation of the cell surface proteome by AMPK activation}

The cell surface proteome is a dynamically regulated compartment of the cell highly involved in many important processes. AMPK is the metabolic stress sensor of the cell and its activation allows cells to respond to changes in their environment to maintain energetic homeostasis. To investigate the effect on the cell surface proteome upon AMPK activation I prepared samples of cell surface proteins using the cell-surface protein purification assay described above ( $\mathrm{n}=4)$; samples were either 1) proteins eluted from beads after cells were not biotinylated (Background), 2) untreated cell-surface proteins (Control), or 3) cell surface proteins

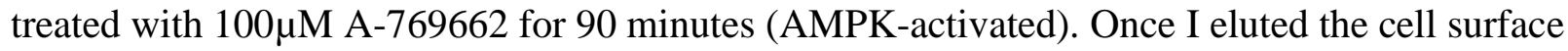
proteins I subjected them to tryptic digestion and prepared them for mass spectrometry injection. Each sample was injected into the LC-ESI-MS/MS. Data for charge states 1, 2, 3, with a minimum peptide length of 4 were run against 4 search engine algorithms (Sequest, Tandem, Mascot, and Omssa) set for a maximum of 2 missed cleavages to identify proteins in each sample. I performed this experiment 4 times with 3 treatments each to make 12 total samples and MS runs. Approximately 30000 peptides and over 400 unique protein identifications were found.

While mass spectrometry is very sensitive and allows detection of proteins often at low abundance, it is possible that either identification of individual peptides/proteins may be 
incorrect. To increase my confidence in the identification of cellular processes that are regulated by AMPK activation, I employed an unbiased clustering approach. This clustering allowed for identification of Gene Ontology (GO) classifications that are collectively up- or down-regulated at the cell surface by AMPK (Figure 13).

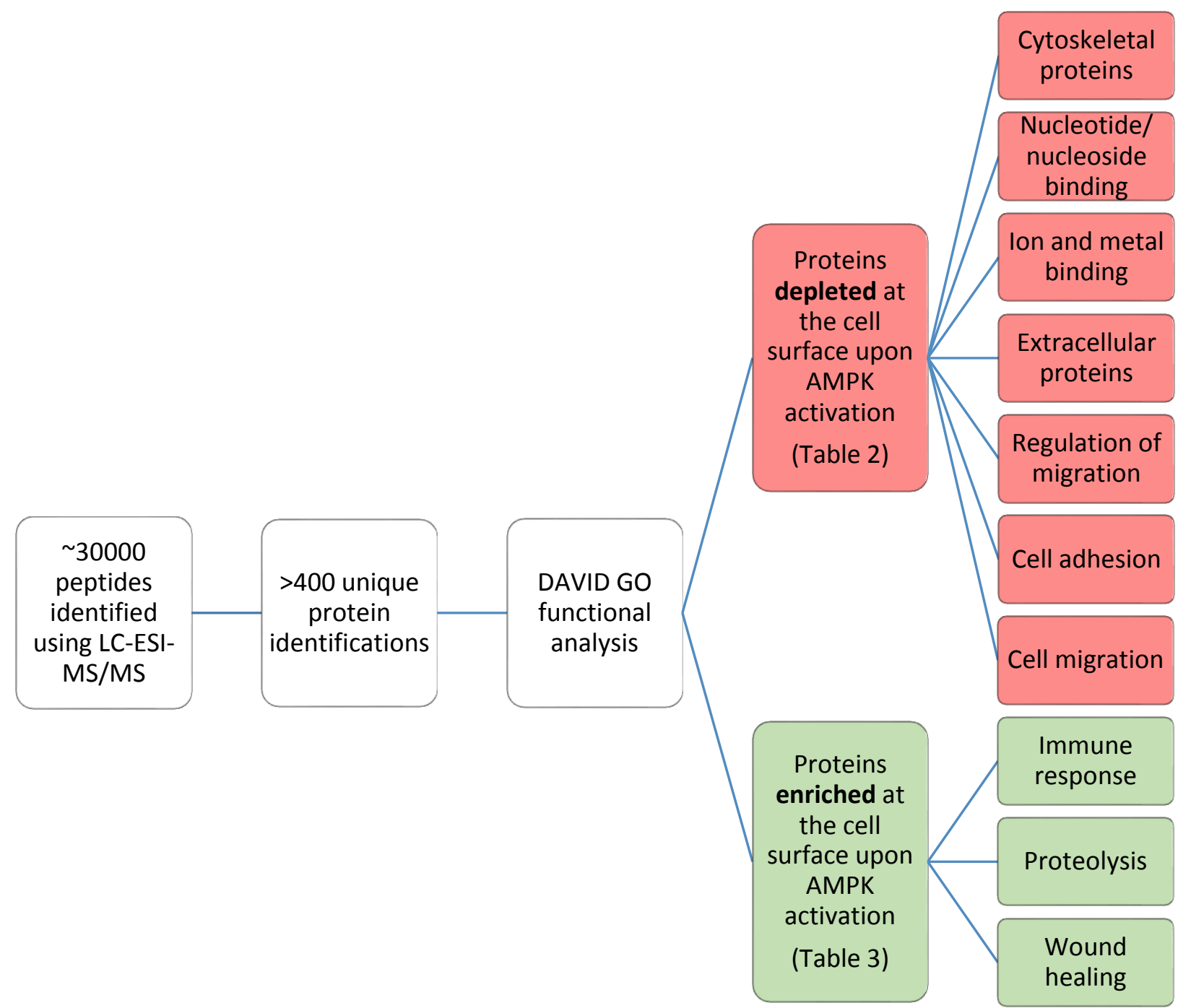

Figure 13 I employed an unbiased clustering approach (D. W. Huang et al., 2009) to proteins identified from the cell-surface biotinylation mass spectrometry screen. This clustering allowed for identification of Gene Ontology (GO) classifications that are collectively up- or down-regulated at the cell surface by AMPK. 
The DAVID bioinformatics resource functional annotation clustering tool (version 6.7; see http://david.abcc.ncifcrf.gov/summary.jsp) measures relationships between GO annotation terms on the basis of the degree of their co-association with genes within the inputted list to create clusters of functional annotation groups (D. W. Huang et al., 2009). This allows for interpretation of MS results at the biological module level (D. W. Huang et al., 2009). It is advantageous to monitor how AMPK regulates biological modules instead of individual proteins, as it is possible that any single peptide or protein is identified incorrectly by the mass spectrometry analysis; the likelihood of large clusters of proteins of similar GO annotation being incorrectly identified is vanishingly small.

The DAVID GO analysis software provides functional annotation clusters and their enrichment scores, p-values, and Benjamini scores. Enrichment scores rank overall enrichment of annotation term groups and is the geometric mean of all the enrichment p-values of each annotation term in the cluster; Greater enrichment scores mean group members are playing more enriched roles in the given study or pathway and scores greater than or equal to 1.3 are considered of note (D. W. Huang et al., 2009). The Benjamini score is a testing correction technique used to globally correct enrichment p-values to control family-wide false discovery rates; Benjamini values that remain significant by the same standards set for $\mathrm{p}$-values indicate a strong relationship (D. W. Huang et al., 2009).

I used the DAVID GO analysis software to cluster identified proteins into functional categories and found several groups of proteins that were depleted or enriched at the cell surface after AMPK-activation (Figure 13).

Using the GO functional analysis, I found the following functional clusters downregulated at the cell surface by AMPK activation: cytoskeletal proteins, nucleotide/nucleoside 
binding, ion and metal binding, extracellular proteins, and interestingly, proteins involved in regulation of migration, cell adhesion, and cell migration, which had enrichment scores of 6.76 , $4.48,3.48,3.06,2.71,2.6$, and 2.59 respectively (Table 2). The significant clusters enriched at the cell surface after AMPK activation were: immune response, proteolysis, and wound healing, which had enrichment scores of 3.06,1.81, and 1.8, respectively (Table 3). Of note, cell adhesion and migration were found with a high degree of confidence (enrichment scores above 1.3) to be regulated by AMPK; 58 of the proteins that were identified are involved in cell adhesion and are regulated at the cell surface by AMPK activation (Table 4). 49 cell surface proteins involved in cell adhesion were down-regulated at the PM upon AMPK activation while 9 were enriched at the PM when AMPK was activated. 
Table 2 DAVID GO functional clustering analysis results for proteins depleted at the cell-surface after AMPK activation.

\section{Functional Annotation Clusters from David Database}

Proteins depleted at the cell-surface after AMPK activation

cytoskeletal proteins

GOTERM_CC_FAT

GOTERM_CC_FAT

GOTERM_CC_FAT

nucleotide/nucleoside binding

GOTERM_MF_FAT

GOTERM_MF_FAT

GOTERM_MF_FAT

GOTERM_MF_FAT

GOTERM_MF_FAT

GOTERM_MF_FAT

GOTERM_MF_FAT

GOTERM_MF_FAT

ion and metal binding proteins

GOTERM_MF_FAT

GOTERM_MF_FAT

GOTERM_MF_FAT

GOTERM_MF_FAT

GOTERM_MF_FAT

extracellular proteins

GOTERM_CC_FAT

GOTERM_CC_FAT

GOTERM_CC_FAT

Regulation of migration

GOTERM_BP_FAT

GOTERM_BP_FAT

GOTERM_BP_FAT

GOTERM_BP_FAT

GOTERM_BP_FAT

GOTERM_BP_FAT

GOTERM_BP_FAT

GOTERM_BP_FAT

Cell Adhesion

GOTERM_BP_FAT

GOTERM_BP_FAT

GOTERM_BP_FAT

Cell migration

GOTERM_BP_FAT

GOTERM_BP_FAT

GOTERM_BP_FAT

GOTERM_BP_FAT
Enrichment Score: 6.76

cytoskeleton

non-membrane-bounded organelle

intracellular non-membrane-bounded organelle

Enrichment Score: $\mathbf{4 . 4 8}$

adenyl nucleotide binding

purine nucleoside binding

nucleoside binding

ATP binding

adenyl ribonucleotide binding

nucleotide binding

purine nucleotide binding

ribonucleotide binding

Enrichment Score: $\mathbf{3 . 4 8}$

ion binding

cation binding

metal ion binding

transition metal ion binding

zinc ion binding

Enrichment Score: 3.06

extracellular region part

extracellular space

extracellular region

Enrichment Score: $\mathbf{2 . 7 1}$

regulation of locomotion

regulation of cell migration

regulation of cell motion

positive regulation of cell migration

positive regulation of locomotion

negative regulation of locomotion

negative regulation of cell migration

positive regulation of cell motion

Enrichment Score: 2.6

cell adhesion

biological adhesion

cell-cell adhesion

Enrichment Score: 2.59

cell motility

localization of cell

cell migration

cell motion

\begin{tabular}{|c|c|c|}
\hline \multicolumn{3}{|c|}{ classification stringency: medium } \\
\hline Count & P_Value & Benjamini \\
\hline 165 & $5 \quad 2.3 \mathrm{E}-08$ & $1.3 \mathrm{E}-05$ \\
\hline 271 & $1.5 \mathrm{E}-07$ & $4.3 \mathrm{E}-05$ \\
\hline 271 & $1.5 \mathrm{E}-07$ & $4.3 \mathrm{E}-05$ \\
\hline Count & P_Value & Benjamini \\
\hline 190 & 2.3E-06 & 2.7E-03 \\
\hline 192 & $2.8 \mathrm{E}-06$ & $1.6 \mathrm{E}-03$ \\
\hline 193 & $2.9 \mathrm{E}-06$ & $1.2 \mathrm{E}-03$ \\
\hline 175 & $1.8 \mathrm{E}-05$ & $5.3 \mathrm{E}-03$ \\
\hline 175 & $3.8 \mathrm{E}-05$ & $8.8 \mathrm{E}-03$ \\
\hline 246 & $7.2 \mathrm{E}-05$ & $1.4 \mathrm{E}-02$ \\
\hline 214 & $8.3 E-05$ & $1.4 \mathrm{E}-02$ \\
\hline 199 & 7.7E-04 & $7.3 \mathrm{E}-02$ \\
\hline Count & P_Value & Benjamini \\
\hline 429 & 1.4E-04 & $2.0 \mathrm{E}-02$ \\
\hline 422 & $2.0 \mathrm{E}-04$ & $2.6 \mathrm{E}-02$ \\
\hline 418 & $2.2 \mathrm{E}-04$ & $2.5 \mathrm{E}-02$ \\
\hline 291 & 4.1E-04 & 4.3E-02 \\
\hline 241 & $1.6 \mathrm{E}-03$ & $1.2 \mathrm{E}-01$ \\
\hline Count & P_Value & Benjamini \\
\hline 110 & 4.9E-05 & $7.0 \mathrm{E}-03$ \\
\hline 75 & $3.2 \mathrm{E}-03$ & $9.8 \mathrm{E}-02$ \\
\hline 190 & 4.0E-03 & $1.1 \mathrm{E}-01$ \\
\hline Count & P_Value & Benjamini \\
\hline 33 & $1.8 \mathrm{E}-04$ & $2.5 \mathrm{E}-02$ \\
\hline 30 & 2.1E-04 & $2.9 \mathrm{E}-02$ \\
\hline 32 & 4.4E-04 & $4.2 \mathrm{E}-02$ \\
\hline 17 & 3.3E-03 & $1.4 \mathrm{E}-01$ \\
\hline 18 & $3.6 \mathrm{E}-03$ & $1.4 \mathrm{E}-01$ \\
\hline 13 & $4.8 \mathrm{E}-03$ & $1.6 \mathrm{E}-01$ \\
\hline 12 & $7.9 \mathrm{E}-03$ & $2.1 \mathrm{E}-01$ \\
\hline 17 & $8.5 \mathrm{E}-03$ & $2.2 \mathrm{E}-01$ \\
\hline Count & P_Value & Benjamini \\
\hline 87 & $3.2 \mathrm{E}-04$ & $3.6 \mathrm{E}-02$ \\
\hline 87 & $3.4 \mathrm{E}-04$ & $3.8 \mathrm{E}-02$ \\
\hline 30 & $1.4 \mathrm{E}-01$ & $7.5 \mathrm{E}-01$ \\
\hline Count & P_Value & Benjamini \\
\hline 43 & $1.5 \mathrm{E}-03$ & $8.9 \mathrm{E}-02$ \\
\hline 43 & $1.5 \mathrm{E}-03$ & $8.9 \mathrm{E}-02$ \\
\hline 38 & $3.9 \mathrm{E}-03$ & $1.5 \mathrm{E}-01$ \\
\hline 58 & $5.2 \mathrm{E}-03$ & $1.7 \mathrm{E}-01$ \\
\hline
\end{tabular}


Table 3 DAVID GO functional clustering analysis results for proteins enriched at the cell-surface after AMPK activation.

\begin{tabular}{|c|c|c|c|c|}
\hline \multicolumn{2}{|r|}{ Functional Annotation Clusters from David Database } & \multirow{2}{*}{\multicolumn{3}{|c|}{ classification stringency: medium }} \\
\hline \multicolumn{2}{|r|}{ Proteins enriched at the cell-surface after AMPK activation } & & & \\
\hline Immune response & Enrichment Score: 3.06 & \multicolumn{2}{|c|}{ ount P_Value } & Benjamini \\
\hline GOTERM_BP_FAT & acute inflammatory response & 10 & $5.6 \mathrm{E}-07$ & $8.1 \mathrm{E}-04$ \\
\hline GOTERM_BP_FAT & activation of plasma proteins involved in acute inflammatory response & 7 & $4.0 \mathrm{E}-06$ & 2.9E-03 \\
\hline GOTERM_BP_FAT & complement activation, classical pathway & 6 & $9.0 \mathrm{E}-06$ & 4.4E-03 \\
\hline GOTERM_BP_FAT & humoral immune response mediated by circulating immunoglobulin & 6 & $1.3 \mathrm{E}-05$ & 4.6E-03 \\
\hline GOTERM_BP_FAT & positive regulation of response to stimulus & 12 & $2.4 \mathrm{E}-05$ & 7.0E-03 \\
\hline GOTERM_BP_FAT & activation of immune response & 8 & $4.2 \mathrm{E}-05$ & $1.0 \mathrm{E}-02$ \\
\hline GOTERM_BP_FAT & immune effector process & 9 & $5.8 \mathrm{E}-05$ & $1.2 \mathrm{E}-02$ \\
\hline GOTERM_BP_FAT & complement activation & 6 & $5.8 \mathrm{E}-05$ & $1.1 \mathrm{E}-02$ \\
\hline GOTERM_BP_FAT & protein processing & 8 & $1.3 \mathrm{E}-04$ & 2.1E-02 \\
\hline GOTERM_BP_FAT & humoral immune response & 7 & $1.4 \mathrm{E}-04$ & $2.0 \mathrm{E}-02$ \\
\hline GOTERM_BP_FAT & immunoglobulin mediated immune response & 6 & $2.0 \mathrm{E}-04$ & 2.6E-02 \\
\hline GOTERM_BP_FAT & protein maturation by peptide bond cleavage & 7 & $2.2 \mathrm{E}-04$ & 2.6E-02 \\
\hline GOTERM_BP_FAT & leukocyte mediated immunity & 7 & $2.2 \mathrm{E}-04$ & 2.6E-02 \\
\hline GOTERM_BP_FAT & protein maturation & 8 & $2.2 \mathrm{E}-04$ & $2.4 \mathrm{E}-02$ \\
\hline GOTERM_BP_FAT & B cell mediated immunity & 6 & $2.3 \mathrm{E}-04$ & 2.4E-02 \\
\hline GOTERM_BP_FAT & complement activation, alternative pathway & 4 & $4.1 \mathrm{E}-04$ & 3.9E-02 \\
\hline GOTERM_BP_FAT & positive regulation of immune response & 8 & $6.2 \mathrm{E}-04$ & $5.5 \mathrm{E}-02$ \\
\hline GOTERM_BP_FAT & lymphocyte mediated immunity & 6 & $6.6 \mathrm{E}-04$ & $5.5 \mathrm{E}-02$ \\
\hline GOTERM_BP_FAT & response to wounding & 15 & $8.3 \mathrm{E}-04$ & $6.2 \mathrm{E}-02$ \\
\hline GOTERM_BP_FAT & adaptive immune response & 6 & $1.0 \mathrm{E}-03$ & $7.2 \mathrm{E}-02$ \\
\hline GOTERM_BP_FAT & somatic recombination of immune receptors & 6 & $1.0 \mathrm{E}-03$ & $7.2 \mathrm{E}-02$ \\
\hline GOTERM_BP_FAT & inflammatory response & 11 & $1.6 \mathrm{E}-03$ & 1.0E-01 \\
\hline GOTERM_CC_FAT & membrane attack complex & 3 & $1.6 \mathrm{E}-03$ & 1.9E-01 \\
\hline GOTERM_BP_FAT & innate immune response & 7 & $2.6 \mathrm{E}-03$ & 1.5E-01 \\
\hline GOTERM_BP_FAT & positive regulation of immune system process & 9 & 2.7E-03 & $1.5 \mathrm{E}-01$ \\
\hline GOTERM_BP_FAT & cytolysis & 3 & $1.8 \mathrm{E}-02$ & $5.0 \mathrm{E}-01$ \\
\hline GOTERM_CC_FAT & extracellular space & 13 & $1.9 \mathrm{E}-02$ & 4.0E-01 \\
\hline GOTERM_CC_FAT & extracellular region part & 16 & $2.3 \mathrm{E}-02$ & 3.6E-01 \\
\hline GOTERM_BP_FAT & immune response & 13 & $4.3 \mathrm{E}-02$ & $6.8 \mathrm{E}-01$ \\
\hline GOTERM_BP_FAT & defense response & 12 & 4.4E-02 & $6.8 \mathrm{E}-01$ \\
\hline Proteolysis & Enrichment Score: 1.81 & Count & P_Value & Benjamini \\
\hline GOTERM_BP_FAT & proteolysis & 23 & $7.2 \mathrm{E}-04$ & 5.7E-02 \\
\hline GOTERM_MF_FAT & exopeptidase activity & 5 & $6.6 \mathrm{E}-03$ & $5.1 \mathrm{E}-01$ \\
\hline GOTERM_MF_FAT & peptidase activity & 13 & $9.9 \mathrm{E}-03$ & $5.5 \mathrm{E}-01$ \\
\hline GOTERM_MF_FAT & peptidase activity, acting on L-amino acid peptides & 12 & $1.8 \mathrm{E}-02$ & $6.2 \mathrm{E}-01$ \\
\hline GOTERM_MF_FAT & carboxypeptidase activity & 3 & $5.0 \mathrm{E}-02$ & $6.5 \mathrm{E}-01$ \\
\hline GOTERM_MF_FAT & metalloexopeptidase activity & 3 & $5.2 \mathrm{E}-02$ & $6.2 \mathrm{E}-01$ \\
\hline GOTERM_MF_FAT & metallopeptidase activity & 5 & $1.0 \mathrm{E}-01$ & 7.4E-01 \\
\hline Wound healing & Enrichment Score: 1.8 & Count & P_Value & Benjamini \\
\hline GOTERM_BP_FAT & response to wounding & 15 & $8.3 \mathrm{E}-04$ & $6.2 \mathrm{E}-02$ \\
\hline GOTERM_BP_FAT & activation of caspase activity & 5 & $2.0 \mathrm{E}-03$ & 1.3E-01 \\
\hline GOTERM_BP_FAT & positive regulation of peptidase activity & 5 & $2.8 \mathrm{E}-03$ & $1.5 \mathrm{E}-01$ \\
\hline GOTERM_BP_FAT & positive regulation of caspase activity & 5 & $2.8 \mathrm{E}-03$ & $1.5 \mathrm{E}-01$ \\
\hline GOTERM_BP_FAT & coagulation & 6 & $3.5 \mathrm{E}-03$ & $1.8 \mathrm{E}-01$ \\
\hline GOTERM_BP_FAT & hemostasis & 6 & $4.5 \mathrm{E}-03$ & 2.2E-01 \\
\hline GOTERM_BP_FAT & regulation of caspase activity & 5 & $8.0 \mathrm{E}-03$ & 3.3E-01 \\
\hline GOTERM_BP_FAT & regulation of endopeptidase activity & 5 & $9.1 \mathrm{E}-03$ & 3.6E-01 \\
\hline GOTERM_BP_FAT & wound healing & 7 & $1.2 \mathrm{E}-02$ & 4.3E-01 \\
\hline GOTERM_BP_FAT & regulation of body fluid levels & 6 & $1.3 \mathrm{E}-02$ & 4.3E-01 \\
\hline GOTERM_BP_FAT & positive regulation of hydrolase activity & 6 & $3.4 \mathrm{E}-02$ & $6.3 \mathrm{E}-01$ \\
\hline GOTERM_BP_FAT & cell death & 13 & $5.6 \mathrm{E}-02$ & 7.0E-01 \\
\hline GOTERM_BP_FAT & death & 13 & $5.8 \mathrm{E}-02$ & 7.0E-01 \\
\hline GOTERM_BP_FAT & regulation of hydrolase activity & 7 & $1.2 \mathrm{E}-01$ & $8.1 \mathrm{E}-01$ \\
\hline GOTERM_BP_FAT & apoptosis & 10 & $1.5 \mathrm{E}-01$ & $8.5 \mathrm{E}-01$ \\
\hline GOTERM_BP_FAT & positive regulation of catalytic activity & 9 & $1.5 \mathrm{E}-01$ & 8.5E-01 \\
\hline GOTERM_BP_FAT & programmed cell death & 10 & 1.6E-01 & $8.6 \mathrm{E}-01$ \\
\hline
\end{tabular}


Table 4 Proteins involved in cell adhesion regulated at the cell surface by AMPK activation. The majority of cell surface adhesion proteins were found to be depleted at the cell surface after AMPK activation.

\begin{tabular}{|c|c|c|}
\hline $\begin{array}{l}\text { Depleted at the Cell-Surface } \\
\text { after AMPK Activation }\end{array}$ & $\begin{array}{l}\text { Depleted at the Cell-Surface } \\
\text { after AMPK Activation }\end{array}$ & $\begin{array}{l}\text { Elevated at the Cell-Surface } \\
\text { after AMPK Activation }\end{array}$ \\
\hline $\begin{array}{l}\text { ADAM metallopeptidase with } \\
\text { thrombospondin type } 1 \text { motif, } 13\end{array}$ & lysyl oxidase-like 2 & D4 molecule \\
\hline $\begin{array}{l}\text { FAT tumor suppressor homolog } 1 \\
\text { (Drosophila) }\end{array}$ & mucin 16 , cell surface associated & PDZ domain containing 2 \\
\hline $\begin{array}{l}\text { FAT tumor suppressor homolog } 2 \\
\text { (Drosophila) }\end{array}$ & $\begin{array}{l}\text { mucin } 5 \mathrm{AC} \text {, oligomeric mucus/gel- } \\
\text { forming; similar to hCG1778310 }\end{array}$ & $\begin{array}{l}\text { cadherin 4, type 1, R-cadherin } \\
\text { (retinal) }\end{array}$ \\
\hline $\begin{array}{l}\text { FAT tumor suppressor homolog } 4 \\
\text { (Drosophila) }\end{array}$ & myosin binding protein $\mathrm{C}$, cardiac & collagen, type XI, alpha 1 \\
\hline LY6/PLAUR domain containing 3 & neural cell adhesion molecule 1 & collagen, type XXII, alpha 1 \\
\hline NEL-like 1 (chicken) & neural cell adhesion molecule 2 & contactin associated protein-like 3; \\
\hline NEL-like 2 (chicken) & neurexin 1 & contactin associated protein-like 3B \\
\hline SCO-spondin homolog (Bos taurus) & neurexin 2 & $\begin{array}{l}\text { discoidin domain receptor tyrosine } \\
\text { kinase } 2\end{array}$ \\
\hline SRY (sex determining region Y)-box 9 & neuropilin 1 & similar to Afadin (Protein AF-6); \\
\hline $\begin{array}{l}\text { amyloid beta (A4) precursor protein- } \\
\text { binding, member } 1\end{array}$ & nidogen 2 (osteonidogen) & $\begin{array}{l}\text { myeloid/lymphoid or mixed-lineage } \\
\text { leukemia (trithorax homolog, }\end{array}$ \\
\hline bone morphogenetic protein 1 & poliovirus receptor-related 3 & Drosophila); translocated to, 4 \\
\hline $\begin{array}{l}\text { catenin (cadherin-associated } \\
\text { protein), alpha-like } 1\end{array}$ & $\begin{array}{l}\text { polycystic kidney and hepatic } \\
\text { disease } 1 \text { (autosomal recessive) }\end{array}$ & tuberous sclerosis 1 \\
\hline $\begin{array}{l}\text { catenin (cadherin-associated } \\
\text { protein), delta } 1\end{array}$ & $\begin{array}{l}\text { protein tyrosine phosphatase, } \\
\text { receptor type, } \mathrm{F}\end{array}$ & \\
\hline $\begin{array}{l}\text { chemokine (C-X-C motif) ligand } 12 \\
\text { (stromal cell-derived factor } 1 \text { ) }\end{array}$ & $\begin{array}{l}\text { protein tyrosine phosphatase, } \\
\text { receptor type, M }\end{array}$ & \\
\hline collagen, type VI, alpha 3 & $\begin{array}{l}\text { protein tyrosine phosphatase, } \\
\text { receptor type, } S\end{array}$ & \\
\hline collagen, type XI, alpha 2 & protocadherin 19 & \\
\hline collagen, type XIV, alpha 1 & protocadherin 7 & \\
\hline discs, large homolog 1 (Drosophila) & $\begin{array}{l}\text { protocadherin beta } 10 \\
\text { protocadherin beta } 9\end{array}$ & \\
\hline fer (fps/fes related) tyrosine kinase & protocadherin gamma subfamily $B, 3$ & \\
\hline $\begin{array}{l}\text { fermitin family homolog } 3 \\
\text { (Drosophila) }\end{array}$ & $\begin{array}{l}\text { sema domain, seven } \\
\text { thrombospondin repeats (type } 1 \text { and } \\
\text { type 1-like), (semaphorin) 5A }\end{array}$ & \\
\hline $\begin{array}{l}\text { fibronectin type III domain } \\
\text { containing } 3 A\end{array}$ & sialic acid binding Ig-like lectin 7 & \\
\hline integrin, alpha 11 & sorbin and $\mathrm{SH} 3$ domain containing 1 & \\
\hline $\begin{array}{l}\text { integrin, alpha } 4 \text { (antigen CD49D, } \\
\text { alpha } 4 \text { subunit of VLA-4 receptor) }\end{array}$ & spleen tyrosine kinase & \\
\hline $\begin{array}{l}\text { intercellular adhesion molecule } 5 \text {, } \\
\text { telencephalin }\end{array}$ & sushi, nidogen and EGF-like domains & \\
\hline trophinin & thrombospondin 2 & \\
\hline
\end{tabular}




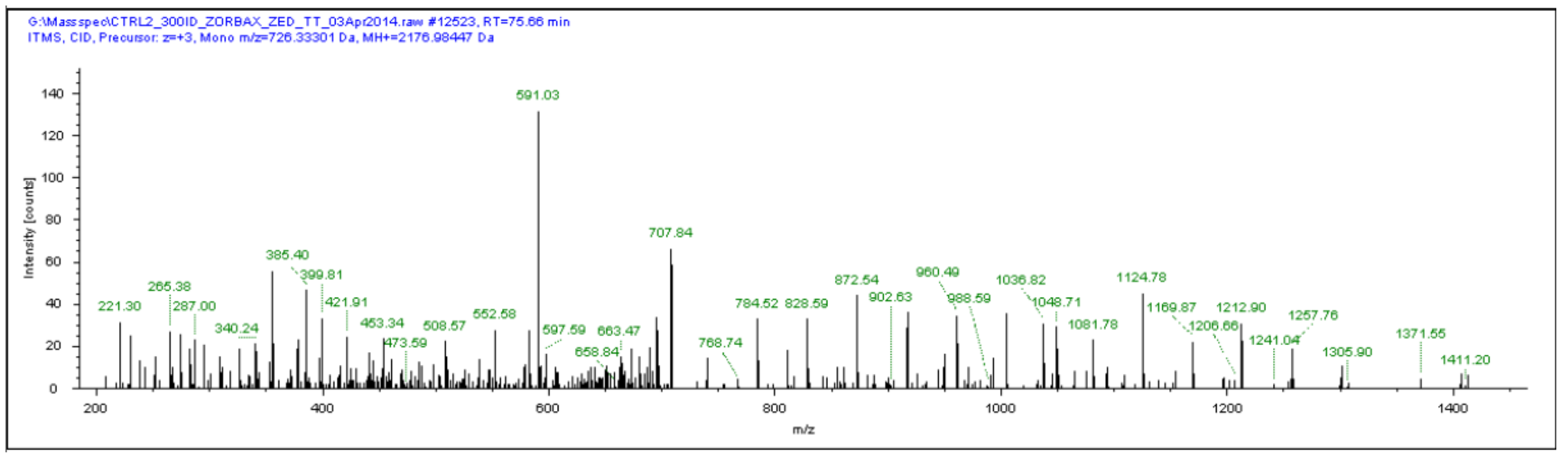

Figure 14 Spectrum of integrin alpha 11 as detected by LC-ESI-MS/MS. 
Integrins are central players for cell adhesion and cell migration. Notably, Integrin $\alpha 4$ and Integrin $\alpha 11$ were two of the proteins involved that were down-regulated at the cell surface by AMPK activation. Shown in Figure 14 is a sample spectrum of integrin $\alpha 11$, demonstrating the suitable signal-to-noise for detection of peptide fragments for this protein.

In summary thus far, I have developed a method that allows systematic identification of cell surface proteins by selective purification and mass spectrometry. I have identified several functional categories of proteins regulated at the cell surface by AMPK activation. Particularly, I identified cell adhesion and migration as processes regulated by AMPK activation. The next question is whether we can confirm that cell adhesion proteins such as integrins are indeed regulated at the level of cell surface abundance by AMPK. 


\section{Results Part II: The specific regulation of $\beta 1$-integrin membrane traffic by AMPK}

\section{$\beta 1$-integrin cell surface content is reduced upon AMPK activation}

Mass spectrometry experiments and functional clustering analysis revealed a connection between AMPK activation and changes in cellular adhesion and migration. $\beta 1$-integrin is the major binding partner for integrins $\alpha 4$ and $\alpha 11$ (identified in the screen) and for other alpha integrins not identified in the screen but known binding partners. $\beta 1$-integrin is, therefore, a candidate target protein to be regulated by AMPK upon energetic stress.

In order to determine if AMPK activation regulates $\beta 1$-integrin on the cell surface, as was found in the mass spectrometry analysis with the $\alpha 4$ - and $\alpha 11$-integrins, I fluorescently labeled cell surface $\beta 1$-integrin in intact control and AMPK-activated cells with an antibody that recognizes an exofacial epitope on $\beta 1$-integrin (Figure 15a). Notably, this antibody does not complete with binding to ECM ligands and does not discriminate between active and inactive integrin, and as such as an optimal reporter of total cell surface $\beta 1$-integrin levels (Jimenez-Soto et al., 2009). In cells treated with A-769662 or AICAR there was less $\beta 1$-integrin on the cell surface compared to untreated cells (Figure 15b).

To confirm that cell surface $\beta 1$-integrin levels are indeed regulated by AMPK activation by a third method, I performed the cell surface protein purification assay characterized above and performed SDS-PAGE with the cell surface proteins (pull down) and with the intracellular proteins (supernatant), followed by a western blot with an antibody against $\beta 1$-integrin. Cells treated with AICAR had decreased $\beta 1$-integrin on the cell surface and increased intracellular $\beta 1$ integrin compared to untreated cells (Figure 15c). Cells treated with EGF as a negative control, 
A

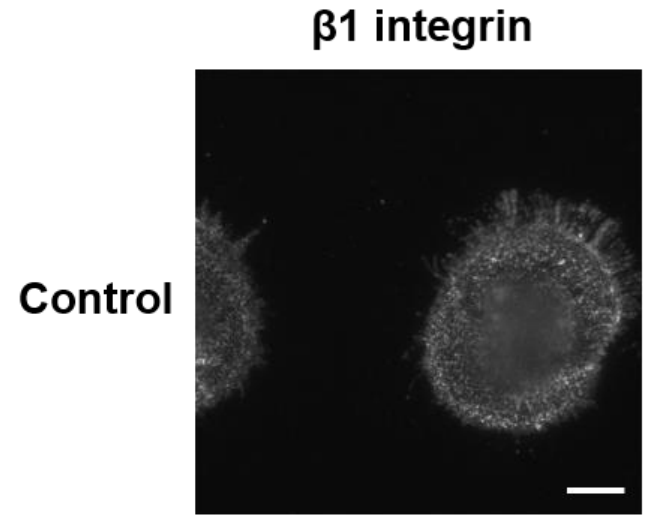

$100 \mu \mathrm{M}$

A-769662

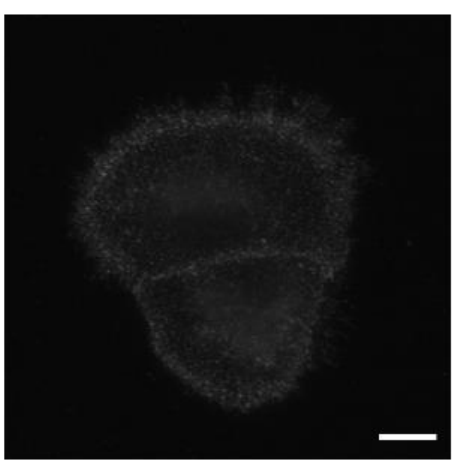

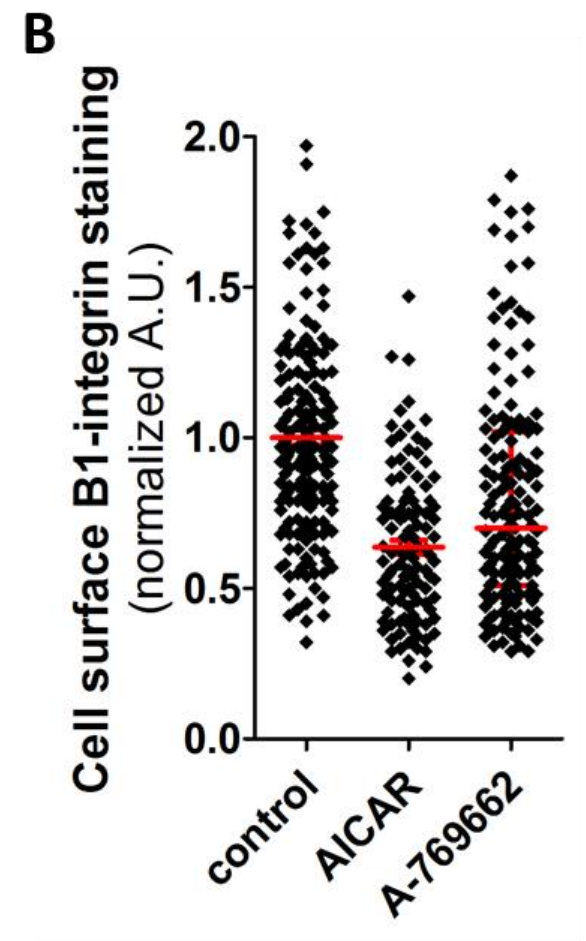

D
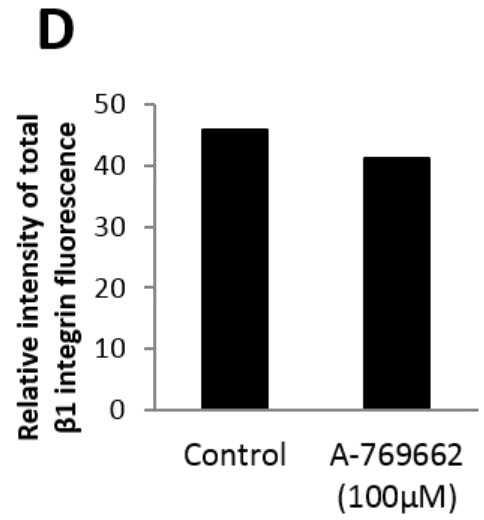

Figure 15 B1-integrin cell surface content is reduced upon AMPK activation. A) Micrographs of cells either treated with $100 \mu \mathrm{M}$ A-769772 or untreated, labelled with an antibody specific to an ectopic $\beta 1$-integrin residue (scale bars $=5 \mu \mathrm{m}$; Quantification in B). C) Western blot with an antibody specific to $\beta 1$-integrin. Protein in the pull-down fraction is cell-surface $\beta 1$-integrin, whereas protein in the supernatant reflects intracellular $\beta 1$ integrin. AMPK activation causes a decrease in $\beta 1$-integrin at the cell surface and an increase in intracellular $\beta 1$-integrin. D) Total levels of $\beta 1$-integrin do not change when AMPK is activated by A-769662. 
showed no decrease in cell surface $\beta 1$-integrin, showing the specificity of regulation of cell surface $\beta 1$-integrin by AMPK activation.

A reduction in cell surface $\beta 1$-integrin could be due to translocation of cell surface $\beta 1$ integrin to intracellular membrane compartment(s), or degradation of $\beta 1$-integrin. To determine if AMPK activation effected a reduction in total levels of $\beta 1$-integrin, I fluorescently labelled all the $\beta 1$-integrin in permeabilized cells treated with A-769662 and in untreated cells. There was no change in total $\beta 1$-integrin levels in cells with activated AMPK (Figure 15d). Hence, the abundance of $\beta 1$-integrin is regulated at the cell surface by AMPK activation mainly through directing membrane traffic to intracellular membrane compartments that do not result in the degradation of $\beta 1$-integrin in the timescale of this experiment (90 min). Whether other cell surface proteins were regulated by AMPK or if this effect was specific to the cell adhesion receptor, $\beta 1$-integrin, remained to be determined.

\section{Transferrin receptor is not regulated at the cell surface by AMPK activation}

To investigate the regulation of other cell surface proteins by AMPK activation, I fluorescently labeled cell surface TfR in intact control and AMPK-activated cells using an antibody to transferrin receptor that recognizes an exofacial epitope (Figure 16a). There was no difference in TfR cell-surface content between control cells and those treated with A-769662 (Figure 16b). Unlike $\beta 1$-integrin, TfR is not regulated at the cell surface by AMPK activation. 
A

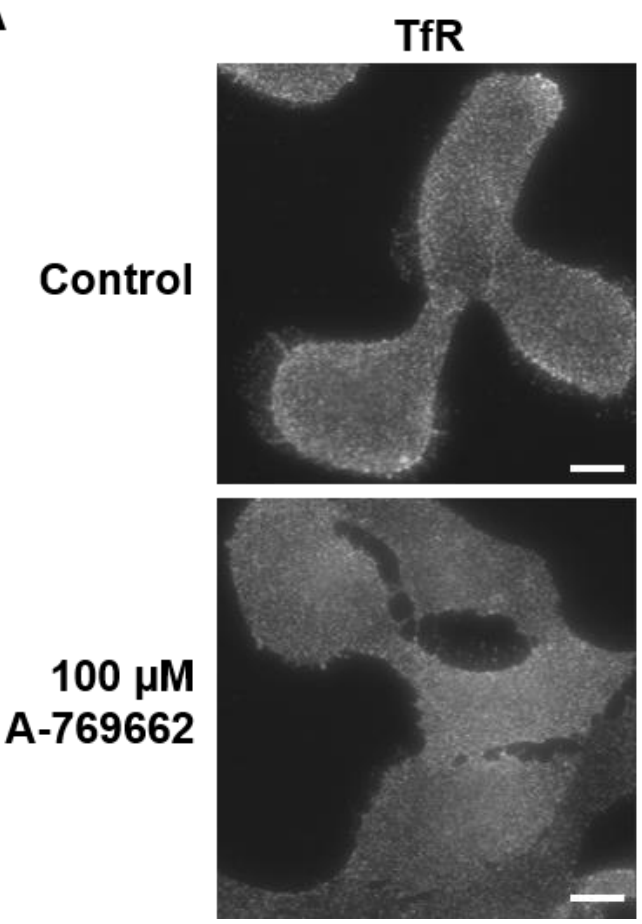

B

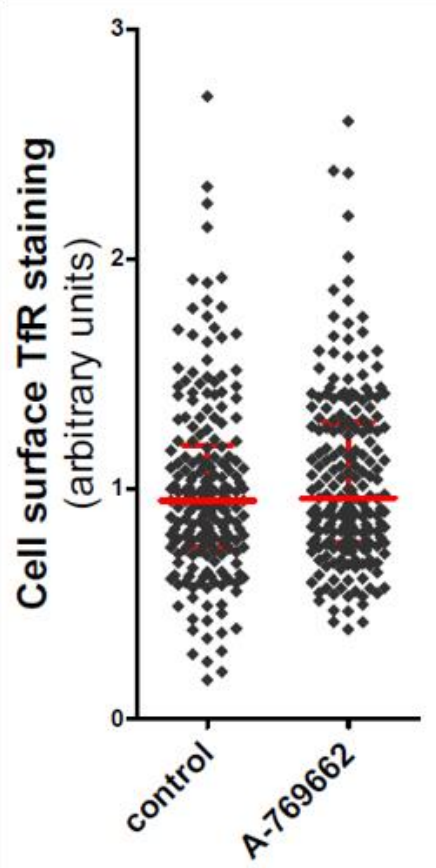

Figure 16 AMPK activation does not regulate TfR abundance at the cell surface. A) Micrographs of RPE cells fluorescently labeled with an antibody recognizing an exofacial epitope on TfR. Cells were untreated or treated with $100 \mu \mathrm{M}$ A-769662 for 90 minutes. TfR abundance does not change at the cell surface when AMPK is activated (Scale bars = $5 \mu \mathrm{m}$; Quantification in B).

Hence, although $\beta 1$-integrin and TfR both internalize primarily through CME followed by intracellular traffic through early and recycling endosomes, the mechanism that effects regulation of $\beta 1$-integrin translocation to the cell interior (e.g. increased endocytosis, decreased recycling or both) is specific and does not control TfR endomembrane traffic.

\section{AMPK activation alters assembly of Dab2-contating CCPs}

$\mathrm{CME}$ is the principle route of internalization of membrane proteins. CCPs are diffraction limited puncta and Dab2 is a CLASP that is required for the CME of $\beta 1$-integrin but not that of TfR. Does AMPK regulate $\beta 1$-integrin on the cell surface through manipulation of Dab2 
recruitment to CCPs? I examined the relationship between Dab2 recruitment to CCPs and AMPK activation using dual-colour TIRF microscopy imaging of RPE cells expressing eGFPCLCa and mCherry-Dab2 (Figure 17a). Diffraction-limited GFP-CLCa puncta were detected by a Gaussian model approach as per Aguet et al. 2013. Dev. Cell. 26:279-91. At each clathrin punctum, the intensity of GFP-CLCa and of mCherry-Dab2 was measured and 2D histograms were created of the GFP-CLC versus mCherry-Dab2 fluorescence intensities (mean values per cell) (Figure 17b). The frequency value of each bin between the control and A-769662 treated conditions were also plotted (Figure 17c). After 60 minutes of A-769662 treatment, Dab2 is recruited to smaller CCPs than in untreated cells. Therefore, AMPK activation alters assembly of Dab2-containing CCPs. 


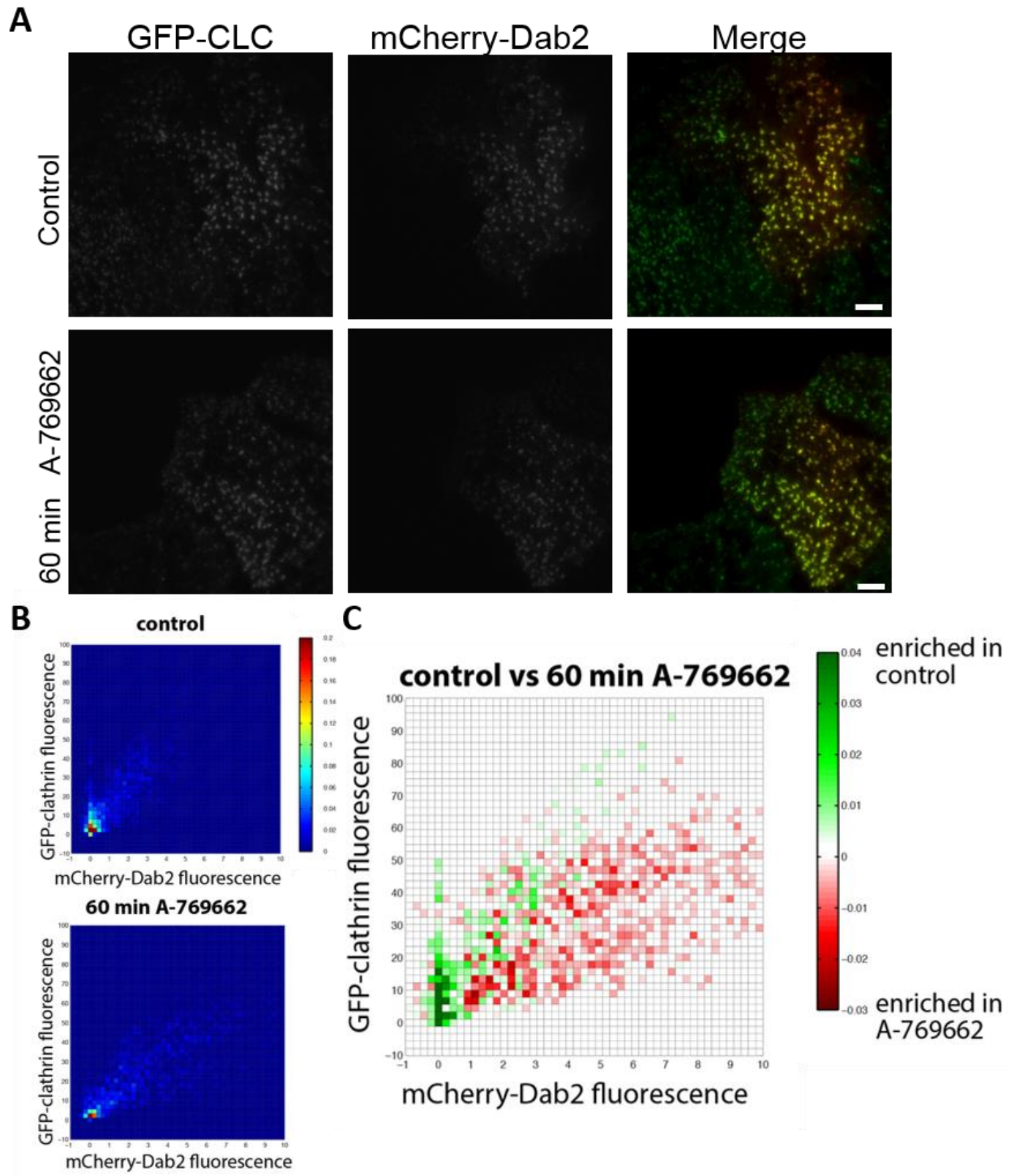

Figure 17 RPE cells stably expressing GRP fused to clathrin light chain (GFP-CLC) and transfected with mCherry-Dab2 were treated with $100 \mu \mathrm{M}$ A-769662 for 60 minutes or left untreated. A) Shown are representative micrographs obtained by total internal reflection fluorescence microscopy. Scale $5 \mu \mathrm{m}$. B) Diffraction-limited GFP-CLC puncta were detected by a Gaussian model approach, as described in Aguet et al. 2013. Dev. Cell. 26:279-91. Shown are 2D histograms of the GFP-CLC versus mCherry-Dab2 fluorescence intensity (mean values per cell). C) Also shown is the difference in the frequency value of each bin between the control and A-769662 treated conditions. 


\section{Discussion}

Understanding how metabolic signaling regulates the cell surface proteome provides important information on mechanisms of membrane traffic and on how cells adapt to changing environments. In mammalian cells, nutrient availability fluctuates at the cellular and tissue level with diet, blood flow, and exercise (Gowans et al., 2013). In addition, nutrient availability also fluctuates at the subcellular level, as has been shown to occur at presynaptic terminus of neurons that undergo ATP stress during synaptic transmission (Rangaraju, Calloway, \& Ryan, 2014). Thus, both rare, dramatic depletion ATP events as well as more frequent, smaller fluctuations of ATP concentration occur in a wide variety of cell types under normal physiological conditions. How these fluctuations in ATP levels controls cell physiology has remained poorly understood.

AMPK is known as the "metabolic stress sensor of the cell" because it recognizes energy limited environments and its activation leads to increasing energy supply and reducing anabolism (Chen et al., 1999). Many targets of AMPK kinase activity are known and well characterised such as the translocation of GLUT-1 (Wu et al., 2013) and GLUT-4 (Klip, Schertzer, Bilan, Thong, \& Antonescu, 2009) to the PM upon AMPK activation to allow for increased glucose uptake in energy-limited environments. Active AMPK also phosphorylates ACC, thereby inactivating it and inhibiting fatty acid synthesis and promoting fatty acid oxidation. The cell surface is a dynamic compartment of the cell and the profile of proteins on the surface of a cell can be remodelled to adapt to different cellular environments.

In this present study, I identified a novel regulation of the cell-surface proteome by AMPK activation. I demonstrated that several functional groups of proteins are either up- or down-regulated in abundance at the plasma membrane as a result of AMPK activation. Of 
primary interest was the discovery that proteins involved in cell adhesion are significantly downregulated in their abundance at the PM upon AMPK activation. I confirmed the regulation of adhesion molecule membrane traffic by AMPK activation by focusing my investigation on $\beta 1$ integrin and its changes in abundance at the cell surface. I showed that upon AMPK activation, $\beta 1$-integrin cell surface levels are decreased and that this regulation correlates with alterations in the assembly of clathrin-coated pits containing Dab2, endocytic structures that specialize in the endocytosis of a subset of cell surface proteins which include $\beta 1$-integrin (Teckchandani et al., 2012).

\section{Regulation of the cell surface proteome by AMPK}

My AMPK-regulated cell-surface protein screen identified cytoskeletal proteins as a functional group regulated by AMPK. From Figure 10b, we can say that any proteins in the "cell-surface" elution are true cell-surface proteins or proteins with tight interactions with cellsurface proteins. Therefore, identifying cytoskeletal proteins in the screen tells us a number of things. First, this identification indicates that AMPK may be regulating either the cytoskeletal proteins identified or, importantly, the cell-surface proteins to which they bind. Integrins are a perfect example of proteins that this identification may point to - they are cell surface proteins that bind ECM and cytoskeletal proteins to form focal contacts and adhesions.

The identification of regulation of cytoskeletal proteins by AMPK also supports evidence that AMPK regulates cell polarity and dynamics (Nakano \& Takashima, 2012; Nakano et al., 2010) and that AMPK induces cytoskeleton reorganization in epithelial cells (Miranda et al., 2010). Establishing polarity is an integral process for several important events such as 
development. Mice that do not express the AMPK $\alpha 1$ and $\alpha 2$ subunits are early embryonic lethal (Viollet et al., 2009). Nakano et al (2010) identified a cytoplasmic linker protein, CLIP-170, in an in vitro screen for AMPK substrates. CLIP-170 is a microtubule plus end protein that binds endocytic vesicles to microtubules (Nakano et al., 2010). AMPK regulation results in alteration of CLIP-170 dynamics on the plus ends of microtubules (Nakano et al., 2010). An interesting phenotype of AMPK depletion that was shown in these studies was a marked enhancement of microtubule stabilization in migrating cells and that AMPK depletion impaired the polarized stabilization of microtubules (Nakano et al., 2010). AMPK has also been shown to induce actin cytoskeleton remodeling in epithelial cells particularly uncoupling from paxillin, predominance of cortical f-actin, and shortening or radiation of stress fibres induced upon AMPK activation (Miranda et al., 2010).

\section{Analysis of changes in the cell surface proteome}

To identify proteins regulated in abundance at the cell surface after AMPK activation, I found the ratio of proteins found in control samples to proteins found in samples treated with A769662 (AMPK-activated) and set the following cut-offs: Control/AMPK-activated total protein identifications $\geq 2$ = Proteins depleted at the cell surface after AMPK activation; Control/AMPKactivated total protein identifications $\leq 0.5=$ Proteins enriched at the cell surface after AMPK activation. This threshold was arbitrary and served as a first approach to identifying changes in abundance of cell surface proteins that is perhaps only suitable to examine changes in clusters of proteins with similar GO annotations, and not of individual proteins. 
Statistical analyses have been described that will allow systematic and unbiased comparison of protein levels in Control versus AMPK-activated conditions based on the number of peptides detected in each condition (Jankowski, Zhu, \& Marshall, 2008). This will be the work of future students and researchers that will use the dataset that I have found for further analyses of changes in the cell-surface proteome as a response to metabolic stress.

There exist several other methods that allow quantification of protein levels between samples including multidimensional protein identification technology (MudPIT) and stable isotope labeling by amino acids in cell culture (SILAC) (S.-E. Ong, 2002; Shao-En Ong, Foster, \& Mann, 2003; Shao-En Ong \& Mann, 2006; Washburn, Wolters, \& Yates, 2001). The disadvantages of these methods are that each requires either specialized instrumentation, specialized proprietary analysis software and/or growing cells in isotope-specific media (for SILAC) which is labour and resource intensive (Shao-En Ong et al., 2003; Shao-En Ong, 2012; Washburn et al., 2001).

The mass spectrometry approach that I enlisted was indeed successful because I identified a GO annotation cluster (cell adhesion and migration) that changes with AMPK activation and I was able to validate this regulation with two other independent methods. Hence, while there are other possibilities to expand upon my approach in the future, my body of work has successfully identified novel candidate cell surface proteins and functions that are regulated by AMPK. 


\section{Coverage of the cell surface proteome by lysine-reactive biotinylation purification strategy}

At the beginning of this study I expected to find certain proteins in the screen to use as positive controls. For example, I expected to find GLUT-1 enriched in control cells versus A769662-treated cells because of previous research showing increased GLUT-1 abundance at the PM after AMPK activation (Wu et al., 2013). Considering that it is a 12-membrane pass protein (Salas-Burgos, Iserovich, Zuniga, Vera, \& Fischbarg, 2004), it is not surprising that GLUT-1 was not present in my screen. I used RIPA buffer in my homogenization process instead of Laemmli sample buffer because it is better for the solubilisation of membrane proteins however proteins with many membrane spanning domains are notoriously difficult to solubilize (Seddon, Curnow, \& Booth, 2004). Hence, while the method that I employed for purification of membrane proteins allowed the identification of the presence and regulation of many integral membrane proteins, this method did not allow detection of all membrane proteins.

Another possible reason why certain cell-surface proteins were not detected is that the reagent used to label cell surface proteins was amine-reactive and therefore, detection of proteins relies on accessible extracellular amines. Furthermore, preparation of mass spectrometry samples involved tryptic digestion and trypsin recognizes positively charged residues and cleaves peptide chains at the carboxyl side of lysine or arginine. Labeling of cell-surface proteins with the amine reactive sulfo-NHS-SS-biotin effectively masks the positive charge on lysines thereby limiting tryptic cleavages sites. Proteins such as $\beta 1$-integrin that have a very large extracellular domain and a very small intracellular domain would have few available tryptic cleavage sites making that protein difficult to detect peptides of this protein by mass spectrometry. Alternate labelling reagents (such as EZ-Link Hydrazide-PEG4-Biotin from Pierce) that bind to carbohydrates are 
available and can be utilized to create another screen to complement the one I described today.

The list of proteins identified by my cell-surface proteome assay is not a complete proteome, however the changes that I detected using consistent labeling methods allowed for identification of processes regulated by AMPK. In this study I focused on the regulation of adhesion molecule membrane traffic by AMPK but many other interesting results may come from exploring the other identified functional groups of proteins identified.

\section{Benefits of LC-ESI-MS/MS in the quantification of peptide identifications}

There are many analytical tools available for the identification of peptides and in this study I chose to analyze my tryptic peptides using LC-ESI-MS/MS. The three main events during MS analysis are ion production, ion transmission, and ion detection (Bakhtiar \& Tse, 2000). Electrospray ionization (ESI) and matrix-assisted laser desorption ionization (MALDI) are complementary ionization approaches that are both sensitive and allow observation of intact polymers with a molecular weight of $100000 \mathrm{Da}$ or higher (Bakhtiar \& Tse, 2000). MALDI uses pulses of laser light to desorb the analyte from a solid phase surface and yield gaseous ions (Bakhtiar \& Tse, 2000). ESI produces gaseous ions that are singly or multiply charged directly from solution by creating a fine spray of highly charged droplets in the presence of a strong electric field (Bakhtiar \& Tse, 2000). ESI ionized molecules from a liquid state whereas MALDI ionizes from a solid state.

Liquid chromatography followed by tandem mass spectrometry has been shown to be more sensitive compared to solid-substrate based methods for protein identification and may detect hundreds of protein in a single experiment (Jankowski et al., 2008; J. Marshall et al., 2004). I 
chose to use ESI for my samples so they could be ionized after liquid chromatography and analysed by tandem mass spectrometry. Another alternative to ESI is nanospray ionization. I did not use nanospray ionization because the distribution of $\mathrm{m} / \mathrm{z}$ detected does not follow a normal distribution and is, therefore, much more challenging to quantify (J. Marshall, personal communication). I based my LC-ESI-MS/MS protocols off of past studies that have successfully quantified changes in peptide abundances using this method (Bowden, Beavis, \& Marshall, 2009; Jankowski et al., 2008; J. Marshall et al., 2004).

My MS analysis identified over 30000 peptides with greater than 400 unique protein identifications (Figure 13). Many of the proteins identified were indeed cell-surface proteins, however I identified a subset of proteins that were putative transcription factors, nuclear pore proteins, and other nuclear contaminants (Appendices 1 and 2). If future MS analyses are required to confirm findings from this study, some strategies to eliminate nuclear contaminations include the addition of calcium and magnesium chelators as well as the addition of RNAse and DNAse crystals to the homogenization buffer.

Although the list of proteins identified through my cell-surface protein assay and LC-ESIMS/MS is not an exhaustive one, it will provide many avenues for further research. I pursued the regulation of cell adhesion and migration by AMPK but there are many other functional clusters that I have identified to be regulated at the PM by AMPK that can be explored.

\section{Regulation of migration by AMPK activation}

Epithelial cell migration is a critical cellular process involved in development, tissue homeostasis, and wound healing. Emerging evidence suggests that cellular energy stress is a key 
regulator of cell adhesion and migration. Activation of AMPK reduces cell adhesion in endothelial progenitor cells (Kaiser et al., 2012), and reduces cell migration in vascular smooth muscle cells (Liang et al., 2008), U937 monocytes (Kanellis et al., 2006), and glioblastoma cells (Ferla et al., 2012). My data support the role of AMPK in regulating adhesion and migration and provide a novel understanding of the mechanism of this regulation. I showed that AMPK regulates cell-surface levels of proteins involved in adhesion and migration and that AMPK activation results in altered assembly of Dab2-containing clathrin coated pits. How AMPK regulates $\beta 1$-integrin levels at the cell surface remains to be uncovered.

$\beta 1$-integrin is present in many integrin complexes and is a critical adhesion molecule involved in multiple cellular processes of adhesion, migration, intracellular signalling, angiogenesis, and invasion. Integrins are regulated by substrate binding and by intracellular signaling, leading to regulation of integrin conformation, and/or membrane traffic (P. T. Caswell et al., 2009). Dab2 is an adaptor protein involved in $\beta 1$-integrin endocytosis. AMPK is emerging as a regulator of membrane traffic (Antonescu et al., 2014) and this present study provides some clues as to how AMPK controls the cell surface proteome. In this study I observed a change in the assembly of Dab2-containing CCPs as a result of AMPK activation. The observed regulation of $\beta 1$-integrin at the cell surface may be a result of changed Dab2-dependent CME.

\section{Regulation of $\beta 1$-integrin membrane traffic by AMPK}

AMPK is a kinase that phosphorylates sites that have at least one basic side chain $(\mathrm{R}, \mathrm{H}$, or $\mathrm{K})$ either 3 or 4 residues $\mathrm{N}$-terminal with respect to the serine or threonine residue phosphorylated. It also requires hydrophobic side chains 4 or 5 residues $\mathrm{N}$-terminal of the 
residue to be phosphorylated (D. G. Hardie, 2011). There are some proteins phosphorylated by AMPK that do not exactly abide by these patterns however AMPK's substrate recognition motifs are very well-defined compared to most protein kinases studied to date (D. G. Hardie, 2011). It is not currently known whether Dab2 is directly phosphorylated by AMPK or not but predictions based on consensus sequence searches indicate that it is not a direct downstream target for the kinase. Dab2 is, however, known to be phosphorylated by a number of kinases including the cyclin-dependent kinase CDC, and protein kinase C (PKC) (He, Xu, Xu, \& Hall, 2003).

Phosphorylation of Dab2 results in changes in subcellular location during mitosis. Dab2 is negatively regulated in mitosis by progressive displacement from the PM paralleled by a loss of co-localization with clathrin, culminating in metaphase/anaphase, and partial recovery in cytokinesis (Chetrit et al., 2011). Negative regulation of Dab2 may be part of an accommodation of the cell to the altered physicochemical conditions prevalent in mitosis (Chetrit et al., 2011). Dab2 is regulated under a variety of context and therefore I expect Dab2 to be highly regulated in varying environments. Dab2 regulation to control endocytosis in response to varying cellular conditions and environments may be a more ubiquitous mechanism of regulation than previously thought.

In this study I showed an interesting correlation between changes in $\beta 1$-integrin abundance at the cell surface and changes in regulation of Dab2-recruitment to CCPs as a result of AMPK activation. These results may be evidence of a pathway that links AMPK and Dab2 (Figure 18), but the opposite conclusion may be suggested as well - perhaps AMPK is directly regulating $\beta 1$ integrin at the cell surface and changes in Dab2-recruitment to CCPs are just a reporter of $\beta 1$ integrin regulation. $\beta 1$-integrin is phosphorylated at S785 and this phosphorylation in both F9 and GD25 cells results in promoted adhesion but inhibited cell spreading and directed cell 


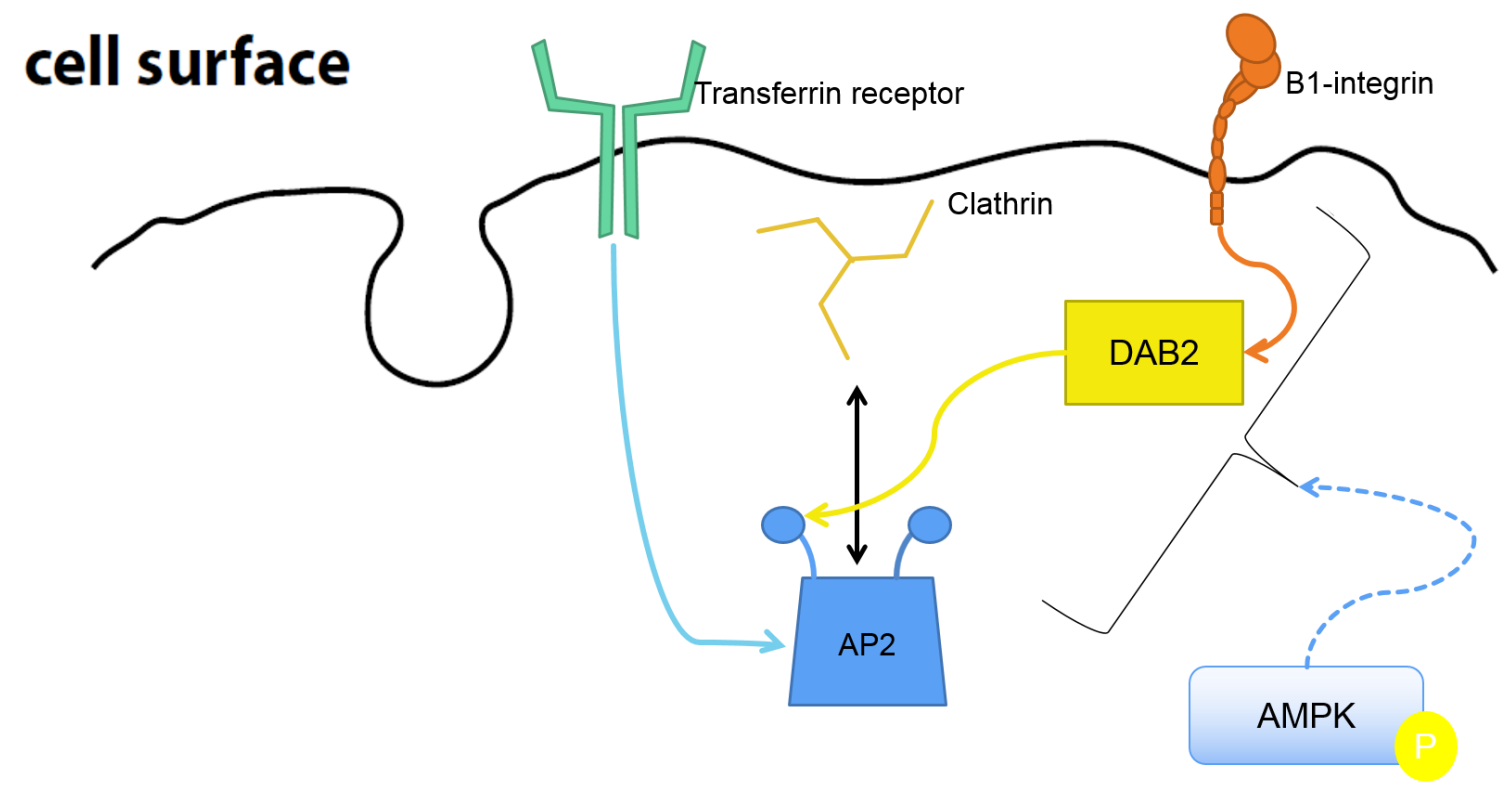

Figure 18 Dab2 is a CLASP that is required for the internalization of $\beta 1$-integrin but not that of Transferrin receptor. My research has shown that AMPK activation results in altered Dab2 recruitment to CCPs. I also showed that AMPK activation regulates adhesion molecules at the PM. AMPK may be regulating adhesion molecule membrane traffic by targeting Dab-2-dependent CME.

migration (Mulrooney, Hong, \& Grabel, 2001). There is a possibility that $\beta 1$-integrin may be phosphorylated by AMPK in order to regulate its endocytosis.

While AMPK can directly phosphorylate a series of substrates, another possible mechanism by which AMPK may regulate cell surface $\beta 1$-integrin is to do so indirectly, through the activation of the p38 MAPK. Activated p38 MAPK has been shown to facilitate the CME of certain PM proteins such as EGFR (Tomas, Futter, \& Eden, 2013; Zwang \& Yarden, 2006) and AMPK activation has been linked to phosphorylation of p38 MAPK (Bae et al., 2011).

Treatment of NCI-H292 cells with the AMPK activator metformin activated phosphorylation of p38 MAPK and treatment with compound C, an inhibitor of AMPK, inhibited metforminactivated phosphorylation of p38 MAPK (Bae et al., 2011). There is a close dependence between AMPK and p38 MAPK in the phosphorylation cascade that leads to energetic stress-dependent apoptosis executed by p53 (Filomeni, Cardaci, Da Costa Ferreira, Rotilio, \& Ciriolo, 2011). 
Furthermore, p38 MAPK has been linked to phosphorylation of $\beta 1$-integrin (Sato et al., 2005). Perhaps p38 MAPK also mediates the response of the cell surface proteome to energetic stress and phosphorylates $\beta 1$-integrin to regulate adhesion at the PM in response to activation by AMPK.

AMPK may also regulate $\beta 1$-integrin cell-surface abundance through regulation of its recycling. Upon internalization, $\beta 1$-integrin localizes to Rab21-positive early endosomes where it is retained by interaction with Rab21 (Pellinen et al., 2006). P120RasGAP displaces the Rab21/integrin interaction and is required for $\beta 1$-integrin exit from Rab21-endosomes (Mai et al., 2011). Overexpression of Rab21 stimulates cell migration and cancer cell adhesion to collagen and human bone, whereas knock down of Rab21 impairs integrin-mediated cell adhesion and motility (Pellinen et al., 2006). Perhaps AMPK regulates the recycling of integrins through phosphorylation of Rab21, p120RasGAP, or $\beta 1$-integrin.

\section{Regulation of AMPK activation during cell migration}

AMPK is activated in response to detection of increased AMP levels as a result of ATP depletion. Considering that ATP is such an important and highly used building block within the cell, massive global decreases in ATP levels are unlikely to be frequent events in many tissues and cells. However, fluctuations or depletions in ATP concentration occur at localized regions within the cell, phenomena tied to highly-energy consuming cellular events are more likely to occur physiologically. For example, ATP is highly consumed during synaptic transmission at the pre-synaptic portion of a neuron, which requires a high rate of local ATP synthesis (Rangaraju et al., 2014). 
Cell migration can potentially create energy-limited domains within the cell. The leading edge of a migrating cell is highly metabolically active because of several processes that occur; rapid membrane traffic of adhesion molecules for disassembly of focal contacts, actin polymerization and depolymerisation events facilitating formation and travel of lamellipodia, and ATPase function of f-actin. It is likely that ATP is locally depleted at the leading edge of migrating cells and that the role I demonstrated for AMPK in regulating adhesion molecules membrane traffic at the cell surface may be highly physiologically relevant here. Migrating cells require coordinated and polarized regulation of their cell surface proteomes. Local ATPdepletion at the leading edge may be one signal to the cell to regulate its adhesion properties by activating AMPK leading to a changed cell-surface distribution of integrins and other cell adhesion proteins.

\section{Specificity of AMPK activation by nucleoside analogues}

In this study, I used the AMP mimetics AICAR and A-769662 to activate AMPK (See Appendix 3). All effects of AMPK activation observed from AICAR treatment were confirmed

with A-769662 treatment. There is a strong movement supporting the use of A-769662 instead of AICAR treatment to activate AMPK both in in vitro studies and in pursuit of possible therapeutic avenues for these compounds (Göransson et al., 2007). AICAR is internalized by adenosine transporters (Gadalla et al., 2004) and is converted by adenosine kinase to the AMP mimetic ZMP within the cells (Corton et al., 1995). Nucleoside transporters (such as adenosine transporters) are integral membrane proteins that mediate and facilitate the cellular intake of nucleosides and nucleobases, nucleoside analog drugs used in the treatment of some cancers and 
viral infections, and they are the target of certain compounds used for cardiovascular disease treatment (Rose \& Coe, 2008). The regulation of the cell surface proteome that I have attributed to the activation of AMPK could possibly be related to the binding of AICAR to nucleoside transporters and the purine signalling that would ensue, however I observed the same effects using A-769662 which is not internalised by nucleoside transporters (Göransson et al., 2007) to activate AMPK.

Another problem with the use of AICAR is that ZMP has been found to regulate other AMP-sensitive enzymes such as glycogen phosphorylase (Longnus et al., 2003), while A-769662 has not been found to have off-target effects (Cool et al., 2006). Furthermore, ZMP, while not an agonist or an antagonist of adenosine receptors, does compete with adenosine for re-uptake into cells (Gadalla et al., 2004) which could have an effect on overall AMP, ADP, and ATP levels. All of my findings have been confirmed with A-769662 and future experiments in my research group will primarily involve the use of A-769662 instead of AICAR. Further studies with AMPK silencing will support the evidence I found for regulation of the cell-surface proteome as a result of AICAR and A-769662 treatment.

\section{Regulation of integrins and cell migration during cancer: possible role of AMPK}

Why does AMPK activation result in a pronounced redistribution of adhesion molecules on the cell surface? What are the implications of this finding? Disseminated disease is the most common cause of death in cancer patients (Brooks, Lomax-Browne, Carter, Kinch, \& Hall, 2010). Metastasis is a complex and poorly understood cascade that allows for tumour cells from a primary focus to colonize a secondary location for proliferation and formation of secondary 
tumours (Brooks et al., 2010). A metastatic tumour cell must complete the entire metastasis cascade (Figure 19) in order to be successful and the vast majority of cancer cells are unable to do so (Brooks et al., 2010).

Metastatic cells colonize different target organs using the bloodstream but can also utilize the lymphatic system (Felding-Habermann, 2003). Metastatic disease cannot progress without the formation of a blood supply to the solid primary tumour mass (Bergers \& Benjamin, 2003) so the metastatic cascade begins with angiogenesis - the development of new blood vessels directed to the site of the primary tumour (Brooks et al., 2010). After a blood source to the tumour is formed, the tumour cells must detach from each other and from their substrate (Brooks et al., 2010). This allows the tumour cells to begin their invasion of and migration through the basement membrane (BM) and ECM and to subsequently invade the BM of the blood vessel endothelium (Brooks et al., 2010). Intravasation follows and the tumour cells can travel through the blood system (Brooks et al., 2010).

A large number of tumour cells make their way to the blood stream but few of them give rise to metastases - survival within the vasculature is difficult considering the shear forces generated by blood flow (Felding-Habermann, 2003). A similarly difficult step in the metastasis cascade is the adhesion of cancer cells to endothelial cells within the blood vessel which prevents the cells from being cleared from circulation and allows for extravasation (Brooks et al., 2010). Integrin supported adhesion of circulating tumour cells is considered the first critical step toward target organ colonization (Abdel-Ghany, Cheng, Elble, \& Pauli, 2002). Once outside of the blood vessel, the tumour cells colonize the target organ site and proliferate to develop a secondary tumour (Brooks et al., 2010). 


\section{1) Angiogenesis}

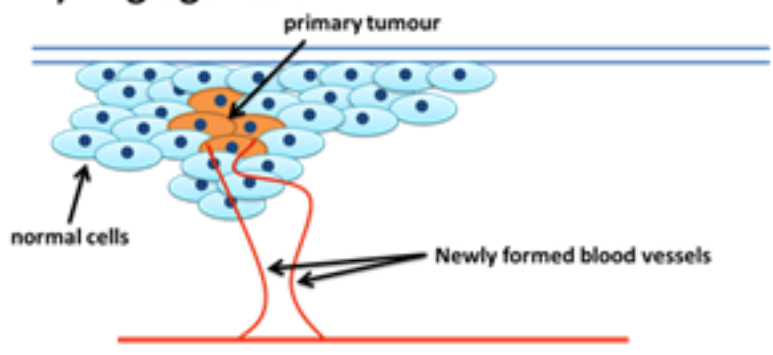

3) Invasion

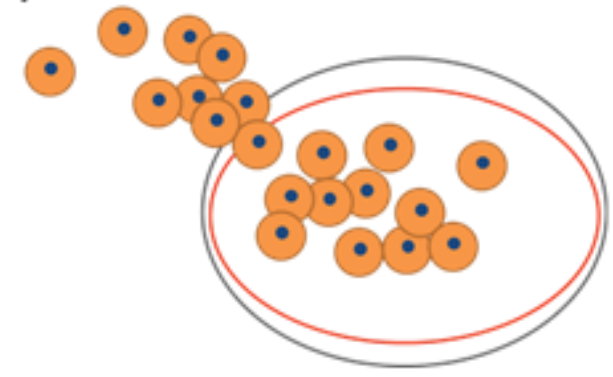

2) De-adhesion of tumour cells

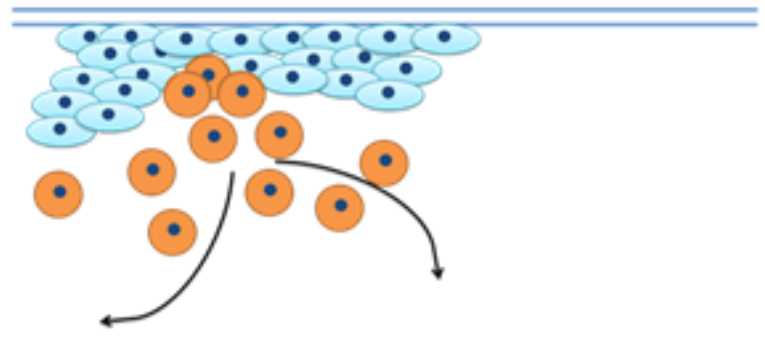

6) Extravasation and 7) Colonization

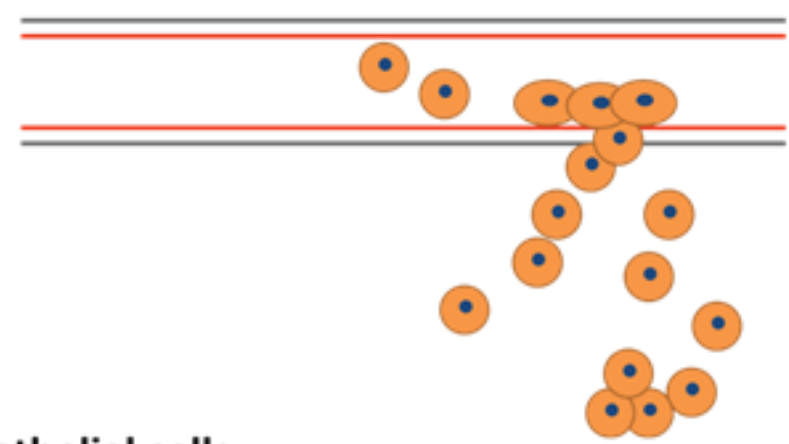

\section{4) Intravasation and 5) Adhesion to endothelial cells}

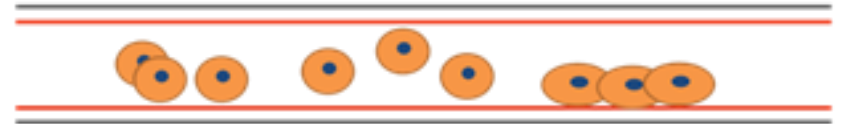

Figure 19 The steps in the metastatic cascade include: 1) Angiogenesis, 2) De-adhesion of tumour cells from the primary location, 3) Invasion, 4) Intravasation, 5) Endothelial adhesion, 6) Extravasation, and 7) Colonization of a secondary location. There are important roles for integrins and other adhesion molecules at each of these steps (adapted from Felding-Habermann, 2003).

p53 is a tumour suppressor gene that is mutated in 50\% of all human cancers (Muller et al., 2009). The mutation results in the loss of tumour suppressor function but still allows for the production of a full length p53 with a point mutation (Muller et al., 2009). Mutant p53 promotes the recycling of integrins and ErbB2, thereby controlling invasion and metastasis (Muller et al., 2009). Interesting, AMPK phosphorylates p53 at serine 15 thereby stabilizing/up-regulating the tumour suppressor protein (D. G. Hardie, 2011; R. G. Jones et al., 2005). AMPK induces a p53dependent metabolic checkpoint by causing G1-S-phase cell cycle arrest (R. G. Jones et al., 2005). Phosphorylation of p53 at serine 15 by AMPK is essential for mediating the effects of 
AMPK on p53-dependent cell-cycle arrest (R. G. Jones et al., 2005). Further studies may investigate the role of p53 in the regulation of cell adhesion by AMPK activation and the effects of loss of p53 function in this system.

Integrins are known to have multiple distinct roles in tumour cell metastasis. Integrin expression in tumour tissue can be very different from normal tissue (Desgrosellier \& Cheresh, 2010). Changes in recycling may affect the profile of integrins on the cell surface and may have implications in tumour cell metastasis progression. For example, integrins $\alpha v \beta 3$, $\alpha 5 \beta 1$, and $\alpha v \beta 6$ are normally expressed at low or undetectable levels in most adult epithelia but can be highly upregulated in some tumours (Desgrosellier \& Cheresh, 2010).

Up-regulation of $\alpha v \beta 3$ is highly implicated in increased invasiveness partly due to its recruitment of matrix metalloproteinases (MMPs) (Koshiba et al., 1998). MMPs degrade the ECM and, therefore, prepare the path for tumour cells to migrate, invade and spread to distant secondary areas (Bourboulia \& Stetler-Stevenson, 2010). Some integrins, such as $\alpha 2 \beta 1$, have decreased expression in tumour cells potentially increasing tumour cell dissemination (Kren et al., 2007).

Studies that have found correlations between integrin expression levels in human tumours and pathological outcomes have identified several integrins that might have crucial roles in cancer progression and may be therapeutic targets (Desgrosellier \& Cheresh, 2010). Integrin antagonists can inhibit tumour growth by affecting tumour cells and also tumour-associated host cells such as the angiogenic endothelium (Desgrosellier \& Cheresh, 2010). Controlling the profile of integrins on the cell surface by changes in their endocytosis may contribute to observed typical integrin over- or under-expression on different cancer cells. 
Although there are clinical trials in progress assessing the safety of function-blocking antibodies against certain integrins known to be overexpressed in proliferating tissues (Avraamides et al., 2008), this type of therapy may present some of the same issues as others that target proliferating cells (such as chemotherapy).

Metformin is an AMPK-activating drug that is commonly administered to treat diabetes. Diabetics treated with metformin had a significantly lower incidence of cancer than those on other treatments (Evans, Donnelly, Emslie-Smith, Alessi, \& Morris, 2005) suggesting that AMPK may be a therapeutic target in cancer treatment and prevention. Supporting this suggestion, treatment of a tumor-prone mouse model with three different AMPK activators metformin, phenformin (a more potent sister drug to metformin), or A-769662 - significantly delayed tumor development (X. Huang et al., 2008). Perhaps the role of AMPK activation protecting against tumor development is attributed or associated with its role in regulating cell surface adhesion molecules.

A better understating of the regulation of the cell-surface proteome and the cellular mechanisms that lead to its remodelling may be crucial in the development of targeted therapies in the treatments of certain cancers. 


\section{Conclusion}

In summary, I have developed an assay to selectively label and purify cell surface proteins for the identification of changes in the cell surface proteome as a result of metabolic stress. Using this assay I identified a novel regulation of the cell-surface proteome by AMPK activation. I demonstrated that several functional groups of proteins are either up- or down-regulated in abundance at the plasma membrane as a result of AMPK activation. Of primary interest was the discovery that proteins involved in cell adhesion are significantly down-regulated in their abundance at the PM upon AMPK activation. I confirmed the regulation of adhesion molecule membrane traffic by AMPK activation by focusing my investigation on $\beta 1$-integrin and its changes in abundance at the cell surface. I showed that upon AMPK activation, $\beta 1$-integrin cell surface levels are decreased and that this regulation correlates with alterations in the assembly of clathrin-coated pits containing Dab2. Discovering the mechanisms by which AMPK regulates the cell surface proteome will allow for a better understanding of how cells respond to their environments in physiological and pathological states and may lead to the development of new therapeutic targets. 


\section{Appendix 1-Top 100 proteins identified in the cell-surface assay to be depleted at the cell-surface after AMPK activation}

\begin{tabular}{|c|c|c|c|c|c|}
\hline Accession & $\begin{array}{c}\text { Total } \\
\text { Protein } \\
\text { Id Count }\end{array}$ & $\begin{array}{c}\text { Total } \\
\text { AMPK- } \\
\text { activated }\end{array}$ & $\begin{array}{l}\text { Total } \\
\text { Control }\end{array}$ & $\begin{array}{c}\text { AMPK- } \\
\text { activated/Control }\end{array}$ & Description \\
\hline gi|000044580 & 74 & 0 & 74 & 0.00 & ZNF142 \\
\hline gi|000044581 & 74 & 0 & 74 & 0.00 & zinc finger protein 142 \\
\hline gi|000044582 & 74 & 0 & 74 & 0.00 & $\begin{array}{l}\text { zinc finger protein } 142 \text { (clone pHZ-49) } \\
\text { isoform CRA_a }\end{array}$ \\
\hline gi|000165626 & 73 & 0 & 73 & 0.00 & Uncharacterized protein \\
\hline gi|000165627 & 73 & 0 & 73 & 0.00 & $\begin{array}{l}\text { zinc finger protein } 142 \text { (clone } \mathrm{pHZ}-49 \text { ) } \\
\text { isoform CRA_b }\end{array}$ \\
\hline gi|000105717 & 68 & 0 & 68 & 0.00 & PREDICTED: hypothetical protein \\
\hline gi|000196646 & 41 & 0 & 41 & 0.00 & $\begin{array}{l}\text { methylcrotonoyl-Coenzyme A } \\
\text { carboxylase } 1 \text { (alpha) isoform CRA_b }\end{array}$ \\
\hline gi|000196647 & 41 & 0 & 41 & 0.00 & $\begin{array}{l}\text { methylcrotonoyl-CoA carboxylase } \\
\text { subunit alpha, mitochondrial } \\
\text { precursor }\end{array}$ \\
\hline gi|000183660 & 35 & 0 & 35 & 0.00 & Myosin-XVIIIb \\
\hline gi|000069900 & 30 & 0 & 30 & 0.00 & LOC100292035 \\
\hline gi|000046342 & 25 & 0 & 25 & 0.00 & adenylate cyclase type 6 isoform b \\
\hline gi|000046343 & 25 & 0 & 25 & 0.00 & adenylate cyclase type 6 isoform a \\
\hline gi|000104447 & 25 & 0 & 25 & 0.00 & hCG1989975 \\
\hline gi|000021948 & 24 & 0 & 24 & 0.00 & Uncharacterized protein TTN \\
\hline gi|000113364 & 23 & 0 & 23 & 0.00 & $\begin{array}{l}\text { CDNA FLJ46154 fis, clone } \\
\text { TESTI4001348 }\end{array}$ \\
\hline gi|000113365 & 23 & 0 & 23 & 0.00 & DCDC5 \\
\hline gi|000113366 & 23 & 0 & 23 & 0.00 & $\begin{array}{l}\text { Doublecortin domain-containing } \\
\text { protein } 5\end{array}$ \\
\hline gi|000032273 & 22 & 0 & 22 & 0.00 & $\begin{array}{l}\text { vacuolar protein sorting } 13 C \text { (yeast) } \\
\text { isoform CRA_i }\end{array}$ \\
\hline gi|000032277 & 22 & 0 & 22 & 0.00 & $\begin{array}{l}\text { vacuolar protein sorting } 13 C \text { (yeast) } \\
\text { isoform CRA_d }\end{array}$ \\
\hline gi|000032271 & 22 & 0 & 22 & 0.00 & $\begin{array}{l}\text { vacuolar protein sorting-associated } \\
\text { protein } 13 \mathrm{C} \text { isoform } 2 \mathrm{~A}\end{array}$ \\
\hline gi|000114461 & 20 & 0 & 20 & 0.00 & Uncharacterized protein \\
\hline gi|000032279 & 20 & 0 & 20 & 0.00 & $\begin{array}{l}\text { vacuolar protein sorting-associated } \\
\text { protein } 13 \mathrm{C} \text { isoform } 1 \mathrm{~A}\end{array}$ \\
\hline gi|000032281 & 20 & 0 & 20 & 0.00 & $\begin{array}{l}\text { vacuolar protein sorting 13C (yeast) } \\
\text { isoform CRA_c }\end{array}$ \\
\hline gi|000032282 & 20 & 0 & 20 & 0.00 & $\begin{array}{l}\text { vacuolar protein sorting } 13 C \text { (yeast) } \\
\text { isoform CRA_a }\end{array}$ \\
\hline
\end{tabular}




\begin{tabular}{|c|c|c|c|c|c|}
\hline Accession & \begin{tabular}{|c|} 
Total \\
Protein \\
Id Count
\end{tabular} & $\begin{array}{c}\text { Total } \\
\text { AMPK- } \\
\text { activated }\end{array}$ & $\begin{array}{l}\text { Total } \\
\text { Control }\end{array}$ & $\begin{array}{c}\text { AMPK- } \\
\text { activated/Control }\end{array}$ & Description \\
\hline gi|000032276 & 19 & 0 & 19 & 0.00 & $\begin{array}{l}\text { vacuolar protein sorting } 13 \mathrm{C} \text { (yeast) } \\
\text { isoform CRA_e }\end{array}$ \\
\hline gi|000032272 & 19 & 0 & 19 & 0.00 & $\begin{array}{l}\text { vacuolar protein sorting } 13 \mathrm{C} \text { (yeast) } \\
\text { isoform CRA_g }\end{array}$ \\
\hline gi|000032267 & 19 & 0 & 19 & 0.00 & Uncharacterized protein \\
\hline gi|000032268 & 19 & 0 & 19 & 0.00 & VPS13C \\
\hline gi|000032269 & 19 & 0 & 19 & 0.00 & $\begin{array}{l}\text { vacuolar protein sorting-associated } \\
\text { protein } 13 \mathrm{C} \text { isoform } 2 \mathrm{~B}\end{array}$ \\
\hline gi|000032270 & 19 & 0 & 19 & 0.00 & VPS13C \\
\hline gi|000085712 & 19 & 0 & 19 & 0.00 & PREDICTED: OTU domain containing 1 \\
\hline gi|000059134 & 18 & 0 & 18 & 0.00 & histone $\mathrm{H} 1.5$ \\
\hline gi|000032274 & 18 & 0 & 18 & 0.00 & $\begin{array}{l}\text { vacuolar protein sorting } 13 \mathrm{C} \text { (yeast) } \\
\text { isoform CRA_b }\end{array}$ \\
\hline gi|000032275 & 18 & 0 & 18 & 0.00 & $\begin{array}{l}\text { vacuolar protein sorting } 13 \mathrm{C} \text { (yeast) } \\
\text { isoform CRA_f }\end{array}$ \\
\hline gi|000098208 & 17 & 0 & 17 & 0.00 & PREDICTED: hypothetical protein \\
\hline gi|000098209 & 17 & 0 & 17 & 0.00 & PREDICTED: hypothetical protein \\
\hline gi|000032278 & 17 & 0 & 17 & 0.00 & $\begin{array}{l}\text { vacuolar protein sorting-associated } \\
\text { protein } 13 C \text { isoform } 1 B\end{array}$ \\
\hline gi|000032280 & 17 & 0 & 17 & 0.00 & $\begin{array}{l}\text { vacuolar protein sorting } 13 \mathrm{C} \text { (yeast) } \\
\text { isoform CRA_h }\end{array}$ \\
\hline gi|000057480 & 17 & 0 & 17 & 0.00 & USP39 \\
\hline gi|000057482 & 17 & 0 & 17 & 0.00 & Uncharacterized protein \\
\hline gi|000057483 & 17 & 0 & 17 & 0.00 & $\begin{array}{l}\text { U4/U6.U5 tri-snRNP-associated } \\
\text { protein } 2\end{array}$ \\
\hline gi|000057485 & 17 & 0 & 17 & 0.00 & Uncharacterized protein \\
\hline gi|000127310 & 17 & 0 & 17 & 0.00 & $\begin{array}{l}\text { protein kinase DNA-activated } \\
\text { catalytic polypeptide isoform CRA_d }\end{array}$ \\
\hline gi|000185093 & 17 & 0 & 17 & 0.00 & ENSP00000313420 \\
\hline gi|000185094 & 17 & 0 & 17 & 0.00 & $\begin{array}{l}\text { protein kinase DNA-activated } \\
\text { catalytic polypeptide isoform CRA_c }\end{array}$ \\
\hline gi|000185096 & 17 & 0 & 17 & 0.00 & $\begin{array}{l}\text { DNA-dependent protein kinase } \\
\text { catalytic subunit isoform } 1\end{array}$ \\
\hline gi|000185095 & 16 & 0 & 16 & 0.00 & $\begin{array}{l}\text { DNA-dependent protein kinase } \\
\text { catalytic subunit isoform } 2\end{array}$ \\
\hline gi|000185091 & 16 & 0 & 16 & 0.00 & $\begin{array}{l}\text { PREDICTED: similar to protein kinase, } \\
\text { DNA-activated, catalytic polypeptide }\end{array}$ \\
\hline gi|000185092 & 16 & 0 & 16 & 0.00 & Uncharacterized protein \\
\hline
\end{tabular}




\begin{tabular}{|c|c|c|c|c|c|}
\hline Accession & $\begin{array}{c}\text { Total } \\
\text { Protein } \\
\text { Id Count }\end{array}$ & $\begin{array}{c}\text { Total } \\
\text { AMPK- } \\
\text { activated }\end{array}$ & $\begin{array}{l}\text { Total } \\
\text { Control }\end{array}$ & $\begin{array}{c}\text { AMPK- } \\
\text { activated/Control }\end{array}$ & Description \\
\hline gi|000048604 & 16 & 0 & 16 & 0.00 & $\begin{array}{l}\text { cDNA FL554020, highly similar to } \\
\text { Heterogeneous nuclear } \\
\text { ribonucleoprotein U }\end{array}$ \\
\hline gi|000048605 & 16 & 0 & 16 & 0.00 & $\begin{array}{l}\text { Heterogeneous nuclear } \\
\text { ribonucleoprotein U }\end{array}$ \\
\hline gi|000048606 & 16 & 0 & 16 & 0.00 & $\begin{array}{l}\text { heterogeneous nuclear } \\
\text { ribonucleoprotein U isoform a }\end{array}$ \\
\hline gi|000048607 & 16 & 0 & 16 & 0.00 & $\begin{array}{l}\text { heterogeneous nuclear } \\
\text { ribonucleoprotein } U \text { isoform b }\end{array}$ \\
\hline gi|000048608 & 16 & 0 & 16 & 0.00 & Uncharacterized protein \\
\hline gi|000019368 & 16 & 0 & 16 & 0.00 & $\begin{array}{l}\text { Heterogeneous nuclear } \\
\text { ribonucleoprotein U (Scaffold } \\
\text { attachment factor A) (Fragment) }\end{array}$ \\
\hline gi|000148282 & 16 & 0 & 16 & 0.00 & HNRPU protein \\
\hline gi|000172891 & 16 & 0 & 16 & 0.00 & $\begin{array}{l}\text { homeodomain-interacting protein } \\
\text { kinase } 3 \text { isoform } 1\end{array}$ \\
\hline gi|000070997 & 16 & 0 & 16 & 0.00 & Uncharacterized protein \\
\hline gi|000056996 & 16 & 0 & 16 & 0.00 & coiled-coil domain containing 102A \\
\hline gi|000056997 & 16 & 0 & 16 & 0.00 & $\begin{array}{l}\text { coiled-coil domain-containing protein } \\
102 \mathrm{~A}\end{array}$ \\
\hline gi|000119930 & 16 & 0 & 16 & 0.00 & $\begin{array}{l}\text { DENN/MADD domain containing 4C } \\
\text { isoform CRA_c }\end{array}$ \\
\hline gi|000119931 & 16 & 0 & 16 & 0.00 & $\begin{array}{l}\text { DENN/MADD domain containing 4C } \\
\text { isoform CRA_d }\end{array}$ \\
\hline gi|000119932 & 16 & 0 & 16 & 0.00 & $\begin{array}{l}\text { DENN/MADD domain containing 4C } \\
\text { isoform CRA_a }\end{array}$ \\
\hline gi|000119933 & 16 & 0 & 16 & 0.00 & $\begin{array}{l}\text { DENN/MADD domain containing 4C } \\
\text { isoform CRA_b }\end{array}$ \\
\hline gi|000103877 & 15 & 0 & 15 & 0.00 & Mucin-16 \\
\hline gi|000158092 & 15 & 0 & 15 & 0.00 & Aldehyde oxidase \\
\hline gi|000158093 & 15 & 0 & 15 & 0.00 & aldehyde oxidase 1 isoform CRA_a \\
\hline gi|000158094 & 15 & 0 & 15 & 0.00 & aldehyde oxidase \\
\hline gi|000158097 & 15 & 0 & 15 & 0.00 & ENSP00000260930 \\
\hline gi|000175598 & 15 & 0 & 15 & 0.00 & Uncharacterized protein \\
\hline gi|000050112 & 15 & 0 & 15 & 0.00 & Ponsin \\
\hline gi|000117272 & 15 & 0 & 11 & 0.00 & Uncharacterized protein \\
\hline gi|000064026 & 14 & 0 & 14 & 0.00 & $\begin{array}{l}\text { cDNA FL51005, highly similar to } \\
\text { Aldehyde oxidase (EC 1.2.3.1) }\end{array}$ \\
\hline gi|000175242 & 14 & 0 & 14 & 0.00 & desmoglein-2 preproprotein \\
\hline
\end{tabular}




\begin{tabular}{|c|c|c|c|c|c|}
\hline Accession & $\begin{array}{l}\text { Total } \\
\text { Protein } \\
\text { Id Count }\end{array}$ & $\begin{array}{c}\text { Total } \\
\text { AMPK- } \\
\text { activated }\end{array}$ & $\begin{array}{l}\text { Total } \\
\text { Control }\end{array}$ & $\begin{array}{c}\text { AMPK- } \\
\text { activated/Control }\end{array}$ & Description \\
\hline gi|000098609 & 14 & 0 & 14 & 0.00 & $\begin{array}{l}\text { mitogen-activated protein kinase- } \\
\text { activated protein kinase } 2 \text { isoform } \\
\text { CRA_g }\end{array}$ \\
\hline gi|000067793 & 14 & 0 & 14 & 0.00 & PREDICTED: hypothetical protein \\
\hline gi|000151760 & 14 & 0 & 14 & 0.00 & $\begin{array}{l}\text { NFX1-type zinc finger-containing } \\
\text { protein } 1\end{array}$ \\
\hline gi|000151763 & 14 & 0 & 14 & 0.00 & $\begin{array}{l}\text { zinc finger NFX1-type containing } 1 \\
\text { isoform CRA_b }\end{array}$ \\
\hline gi|000072324 & 13 & 0 & 13 & 0.00 & ARFGAP3 \\
\hline gi|000151793 & 13 & 0 & 13 & 0.00 & $\begin{array}{l}\text { PREDICTED: similar to Protein MICAL- } \\
3\end{array}$ \\
\hline gi|000170463 & 13 & 0 & 13 & 0.00 & $\begin{array}{l}\text { biorientation of chromosomes in cell } \\
\text { division protein 1-like }\end{array}$ \\
\hline gi|000038950 & 13 & 0 & 10 & 0.00 & Solute carrier family 12 member 8 \\
\hline gi|000038951 & 13 & 0 & 10 & 0.00 & Solute carrier family 12 member 8 \\
\hline gi|000038953 & 13 & 0 & 10 & 0.00 & solute carrier family 12 member 8 \\
\hline gi|000101754 & 13 & 0 & 13 & 0.00 & protein phosphatase $1 \mathrm{~J}$ \\
\hline gi|000101755 & 13 & 0 & 13 & 0.00 & hCG1997303 isoform CRA_c \\
\hline gi|000101756 & 13 & 0 & 13 & 0.00 & hCG1997303 isoform CRA_f \\
\hline gi|000206075 & 13 & 0 & 13 & 0.00 & LOC646976 \\
\hline gi|000056608 & 13 & 0 & 13 & 0.00 & hemicentin 1 isoform CRA_a \\
\hline gi|000101266 & 13 & 0 & 10 & 0.00 & SLC12A8 \\
\hline gi|000101267 & 13 & 0 & 10 & 0.00 & ZNF148 \\
\hline gi|000008646 & 13 & 0 & 10 & 0.00 & SLC12A8 \\
\hline gi|000147794 & 12 & 0 & 12 & 0.00 & cDNA FLJ75603 \\
\hline gi|000130433 & 12 & 0 & 12 & 0.00 & $\begin{array}{l}\text { zinc finger RAN-binding domain } \\
\text { containing } 3 \text { isoform CRA_c }\end{array}$ \\
\hline gi|000130434 & 12 & 0 & 12 & 0.00 & $\begin{array}{l}\text { zinc finger RAN-binding domain } \\
\text { containing } 3 \text { isoform CRA_f }\end{array}$ \\
\hline gi|000068277 & 12 & 0 & 12 & 0.00 & $\begin{array}{l}\text { cDNA, FLJ96929, highly similar to } \\
\text { Homo sapiens taste receptor, type } 1 \text {, } \\
\text { member } 1 \text { (TAS1R1), mRNA }\end{array}$ \\
\hline gi|000051151 & 12 & 0 & 12 & 0.00 & $\begin{array}{l}\text { topoisomerase (DNA) II binding } \\
\text { protein } 1 \text { isoform CRA_b }\end{array}$ \\
\hline gi|000046164 & 12 & 0 & 12 & 0.00 & USP54 \\
\hline gi|000103526 & 12 & 0 & 12 & 0.00 & $\begin{array}{l}\text { taste receptor type } 1 \text { member } 1 \\
\text { isoform b precursor }\end{array}$ \\
\hline
\end{tabular}




\section{Appendix 2-Top 100 Proteins identified in the cell-surface assay to be enriched at the cell-surface after AMPK activation}

\begin{tabular}{|c|c|c|c|c|c|}
\hline Accession & $\begin{array}{c}\text { Total } \\
\text { Protein } \\
\text { Id Count }\end{array}$ & $\begin{array}{c}\text { Total } \\
\text { AMPK- } \\
\text { activated }\end{array}$ & $\begin{array}{l}\text { Total } \\
\text { Control }\end{array}$ & $\begin{array}{c}\text { Control/ } \\
\text { AMPK- } \\
\text { activated }\end{array}$ & Description \\
\hline gi|000166661 & 18 & 16 & 0 & 0.00 & homeobox D12 \\
\hline gi|000166663 & 18 & 16 & 0 & 0.00 & Homeobox protein Hox-D12 \\
\hline gi|000084178 & 8 & 8 & 0 & 0.00 & $\begin{array}{l}\text { latent-transforming growth factor beta- } \\
\text { binding protein } 3 \text { isoform } 2 \text { precursor }\end{array}$ \\
\hline gi|000084179 & 8 & 8 & 0 & 0.00 & $\begin{array}{l}\text { latent-transforming growth factor beta- } \\
\text { binding protein } 3 \text { isoform } 1 \text { precursor }\end{array}$ \\
\hline gi|000149607 & 7 & 6 & 0 & 0.00 & ubiquitin carboxyl-terminal hydrolase 12 \\
\hline gi|000149608 & 7 & 6 & 0 & 0.00 & ubiquitin specific peptidase 12 isoform CRA_b \\
\hline gi|000149609 & 7 & 6 & 0 & 0.00 & ubiquitin-specific protease 12 -like 1 \\
\hline gi|000143814 & 7 & 7 & 0 & 0.00 & GOLGA4 \\
\hline gi|000138841 & 7 & 7 & 0 & 0.00 & $\begin{array}{l}\text { golgi autoantigen golgin subfamily a } 4 \text { isoform } \\
\text { CRA_a }\end{array}$ \\
\hline gi|000138842 & 7 & 7 & 0 & 0.00 & Golgin subfamily A member 4 isoform 1 \\
\hline gi|000138836 & 7 & 7 & 0 & 0.00 & Golgin subfamily A member 4 isoform 2 \\
\hline gi|000138837 & 7 & 7 & 0 & 0.00 & GOLGA4 \\
\hline gi|000138838 & 7 & 7 & 0 & 0.00 & GOLGA4 \\
\hline gi|000202964 & 7 & 6 & 0 & 0.00 & USP12 \\
\hline gi|000138834 & 7 & 7 & 0 & 0.00 & $\begin{array}{l}\text { golgi autoantigen golgin subfamily a } 4 \text { isoform } \\
\text { CRA_c }\end{array}$ \\
\hline gi|000138835 & 7 & 7 & 0 & 0.00 & GOLGA4 \\
\hline gi|000022138 & 7 & 7 & 0 & 0.00 & ENSP00000405842 \\
\hline gi|000150329 & 6 & 6 & 0 & 0.00 & $\begin{array}{l}\text { myosin light polypeptide kinase isoform } \\
\text { CRA_g }\end{array}$ \\
\hline gi|000050144 & 6 & 6 & 0 & 0.00 & $\begin{array}{l}\text { Putative uncharacterized protein } \\
\text { DKFZp451A123 }\end{array}$ \\
\hline gi|000050146 & 6 & 6 & 0 & 0.00 & myosin-2 \\
\hline gi|000127760 & 5 & 5 & 0 & 0.00 & hCG1778643 \\
\hline gi|000127761 & 5 & 5 & 0 & 0.00 & CDNA FLJ13262 fis, clone OVARC1000912 \\
\hline gi|000077458 & 5 & 5 & 0 & 0.00 & Uncharacterized protein \\
\hline gi|000077459 & 5 & 5 & 0 & 0.00 & $\begin{array}{l}\text { cDNA FL55879, highly similar to Homo } \\
\text { sapiens SH3 multiple domains } 1 \text { (SH3MD1), } \\
\text { mRNA }\end{array}$ \\
\hline gi|000048683 & 5 & 5 & 0 & 0.00 & nuclear receptor corepressor 1 isoform 1 \\
\hline gi|000048694 & 5 & 5 & 0 & 0.00 & Uncharacterized protein \\
\hline gi|000048685 & 5 & 5 & 0 & 0.00 & NCOR1 \\
\hline gi|000048686 & 5 & 5 & 0 & 0.00 & NCOR1 \\
\hline
\end{tabular}




\begin{tabular}{|c|c|c|c|c|c|}
\hline Accession & $\begin{array}{c}\text { Total } \\
\text { Protein } \\
\text { Id Count }\end{array}$ & $\begin{array}{c}\text { Total } \\
\text { AMPK- } \\
\text { activated }\end{array}$ & $\begin{array}{l}\text { Total } \\
\text { Control }\end{array}$ & $\begin{array}{c}\text { Control/ } \\
\text { AMPK- } \\
\text { activated }\end{array}$ & Description \\
\hline gi|000048515 & 5 & 5 & 0 & 0.00 & Nuclear receptor co-repressor \\
\hline gi|000162372 & 5 & 5 & 0 & 0.00 & MYLK \\
\hline gi|000194262 & 4 & 4 & 0 & 0.00 & hCG27698 isoform CRA_d \\
\hline gi|000194257 & 4 & 4 & 0 & 0.00 & $\begin{array}{l}\text { probable ATP-dependent RNA helicase DDX47 } \\
\text { isoform } 2\end{array}$ \\
\hline gi|000194258 & 4 & 4 & 0 & 0.00 & DEAD box protein \\
\hline gi|000194259 & 4 & 4 & 0 & 0.00 & $\begin{array}{l}\text { probable ATP-dependent RNA helicase DDX47 } \\
\text { isoform } 1\end{array}$ \\
\hline gi|000102569 & 4 & 4 & 0 & 0.00 & GOLGB1 \\
\hline gi|000039245 & 4 & 4 & 0 & 0.00 & ENSP00000409619 \\
\hline gi|000023593 & 4 & 4 & 0 & 0.00 & YLP motif-containing protein 1 \\
\hline gi|000023595 & 4 & 4 & 0 & 0.00 & hCG22358 isoform CRA_c \\
\hline gi|000023596 & 4 & 4 & 0 & 0.00 & YLPM1 \\
\hline gi|000023597 & 4 & 4 & 0 & 0.00 & YLP motif-containing protein 1 \\
\hline gi|000066309 & 4 & 4 & 0 & 0.00 & Uncharacterized protein \\
\hline gi|000129133 & 4 & 4 & 0 & 0.00 & $\begin{array}{l}\text { PREDICTED: similar to Serine/threonine- } \\
\text { protein kinase Pim-3 }\end{array}$ \\
\hline gi|000075557 & 4 & 4 & 0 & 0.00 & PREDICTED: hypothetical protein \\
\hline gi|000045500 & 4 & 4 & 0 & 0.00 & ENSP00000295971 \\
\hline gi|000045501 & 4 & 4 & 0 & 0.00 & RNA-binding protein 47 \\
\hline gi|000045502 & 4 & 4 & 0 & 0.00 & RNA-binding protein 47 isoform a \\
\hline gi|000045503 & 4 & 4 & 0 & 0.00 & RNA-binding protein isoform CRA_C \\
\hline gi|000045504 & 4 & 4 & 0 & 0.00 & RNA-binding protein isoform CRA_a \\
\hline gi|000045505 & 4 & 4 & 0 & 0.00 & RNA binding motif protein 47 \\
\hline gi|000149991 & 4 & 4 & 0 & 0.00 & $\begin{array}{l}\text { cDNA FL61302, highly similar to Glutamate } \\
\text { receptor, ionotropic kainate } 1\end{array}$ \\
\hline gi|000043699 & 4 & 4 & 0 & 0.00 & $\begin{array}{l}\text { cDNA FLJ30924 fis, clone FEBRA2006521, } \\
\text { highly similar to Junctophilin-3 }\end{array}$ \\
\hline gi|000186245 & 4 & 4 & 0 & 0.00 & Uncharacterized protein \\
\hline gi|000101718 & 4 & 4 & 0 & 0.00 & MAP1D \\
\hline gi|000125651 & 4 & 4 & 0 & 0.00 & $\begin{array}{l}\text { high affinity cGMP-specific 3,5-cyclic } \\
\text { phosphodiesterase 9A isoform o }\end{array}$ \\
\hline gi|000125653 & 4 & 4 & 0 & 0.00 & $\begin{array}{l}\text { high affinity cGMP-specific 3,5-cyclic } \\
\text { phosphodiesterase } 9 A \text { isoform a }\end{array}$ \\
\hline gi|000051819 & 4 & 4 & 0 & 0.00 & Hqp0256 protein \\
\hline gi|000016938 & 4 & 4 & 0 & 0.00 & PDE9A \\
\hline gi|000025623 & 4 & 4 & 0 & 0.00 & $\begin{array}{l}\text { apoptotic chromatin condensation inducer in } \\
\text { the nucleus isoform } 3\end{array}$ \\
\hline gi|000025624 & 4 & 4 & 0 & 0.00 & Uncharacterized protein \\
\hline
\end{tabular}




\begin{tabular}{|c|c|c|c|c|c|}
\hline Accession & $\begin{array}{c}\text { Total } \\
\text { Protein } \\
\text { Id Count }\end{array}$ & $\begin{array}{c}\text { Total } \\
\text { AMPK- } \\
\text { activated }\end{array}$ & $\begin{array}{l}\text { Total } \\
\text { Control }\end{array}$ & $\begin{array}{l}\text { Control/ } \\
\text { AMPK- } \\
\text { activated }\end{array}$ & Description \\
\hline gi|000025625 & 4 & 4 & 0 & 0.00 & $\begin{array}{l}\text { apoptotic chromatin condensation inducer in } \\
\text { the nucleus isoform } 2\end{array}$ \\
\hline gi|000025626 & 4 & 4 & 0 & 0.00 & $\begin{array}{l}\text { apoptotic chromatin condensation inducer in } \\
\text { the nucleus isoform } 1\end{array}$ \\
\hline gi|000025627 & 4 & 4 & 0 & 0.00 & ENSP00000451328 \\
\hline gi|000025628 & 4 & 4 & 0 & 0.00 & $\begin{array}{l}\text { Apoptotic chromatin condensation inducer in } \\
\text { the nucleus }\end{array}$ \\
\hline gi|000143772 & 4 & 4 & 0 & 0.00 & Uncharacterized protein \\
\hline gi|000049856 & 4 & 4 & 0 & 0.00 & junctophilin-3 \\
\hline gi|000093136 & 4 & 4 & 0 & 0.00 & $\begin{array}{l}\text { polycystic kidney disease } 2 \text {-like } 1 \text { isoform } \\
\text { CRA_b }\end{array}$ \\
\hline gi|000051971 & 4 & 4 & 0 & 0.00 & $\begin{array}{l}\text { cDNA FLU60694, highly similar to } \\
\text { Deubiquitinating protein VCIP135 (EC 3.4.22.-) }\end{array}$ \\
\hline gi|000051972 & 4 & 4 & 0 & 0.00 & deubiquitinating protein VCIP135 \\
\hline gi|000032614 & 4 & 4 & 0 & 0.00 & hypothetical protein FLJ14668 isoform CRA_b \\
\hline gi|000164401 & 4 & 4 & 0 & 0.00 & $\begin{array}{l}\text { high affinity cGMP-specific 3,5-cyclic } \\
\text { phosphodiesterase 9A isoform m }\end{array}$ \\
\hline gi|000164403 & 4 & 4 & 0 & 0.00 & $\begin{array}{l}\text { high affinity cGMP-specific 3,5-cyclic } \\
\text { phosphodiesterase } 9 A \text { isoform n }\end{array}$ \\
\hline gi|000193929 & 4 & 4 & 0 & 0.00 & $\begin{array}{l}\text { methionine aminopeptidase 1D, } \\
\text { mitochondrial precursor }\end{array}$ \\
\hline gi|000209331 & 4 & 4 & 0 & 0.00 & $\begin{array}{l}\text { DEAD (Asp-Glu-Ala-Asp) box polypeptide } 47 \\
\text { isoform } 1 \text { variant (Fragment) }\end{array}$ \\
\hline gi|000183578 & 3 & 2 & 0 & 0.00 & Uncharacterized protein \\
\hline gi|000183579 & 3 & 2 & 0 & 0.00 & $\begin{array}{l}\text { cDNA FL54283, highly similar to Heat shock } \\
70 \text { kDa protein } 1\end{array}$ \\
\hline gi|000183580 & 3 & 2 & 0 & 0.00 & $\begin{array}{l}\text { cDNA FLJ54407, highly similar to Heat shock } \\
70 \text { kDa protein } 1\end{array}$ \\
\hline gi|000183581 & 3 & 2 & 0 & 0.00 & $\begin{array}{l}\text { cDNA FLJ54389, highly similar to Heat shock } \\
70 \text { kDa protein } 1\end{array}$ \\
\hline gi|000183586 & 3 & 2 & 0 & 0.00 & $\begin{array}{l}\text { CDNA FL54328, highly similar to Heat shock } \\
70 \text { kDa protein } 1\end{array}$ \\
\hline gi|000183587 & 3 & 2 & 0 & 0.00 & Uncharacterized protein \\
\hline gi|000183588 & 3 & 2 & 0 & 0.00 & Uncharacterized protein \\
\hline gi|000183589 & 3 & 2 & 0 & 0.00 & $\begin{array}{l}\text { cDNA FLJ54392, highly similar to Heat shock } \\
70 \text { kDa protein } 1\end{array}$ \\
\hline gi|000183590 & 3 & 2 & 0 & 0.00 & $\begin{array}{l}\text { cDNA FL54408, highly similar to Heat shock } \\
70 \text { kDa protein } 1\end{array}$ \\
\hline
\end{tabular}




\begin{tabular}{|c|c|c|c|c|c|}
\hline Accession & $\begin{array}{c}\text { Total } \\
\text { Protein } \\
\text { Id Count }\end{array}$ & $\begin{array}{c}\text { Total } \\
\text { AMPK- } \\
\text { activated }\end{array}$ & $\begin{array}{l}\text { Total } \\
\text { Control }\end{array}$ & $\begin{array}{l}\text { Control/ } \\
\text { AMPK- } \\
\text { activated }\end{array}$ & Description \\
\hline gi|000183591 & 3 & 2 & 0 & 0.00 & heat shock 70kDa protein 1B \\
\hline gi|000183592 & 3 & 2 & 0 & 0.00 & heat shock $70 \mathrm{kDa}$ protein $1 \mathrm{~A} / 1 \mathrm{~B}$ \\
\hline gi|000183593 & 3 & 2 & 0 & 0.00 & heat shock 70kDa protein $1 \mathrm{~A}$ \\
\hline gi|000183594 & 3 & 2 & 0 & 0.00 & $\begin{array}{l}\text { cDNA FLJ54303, highly similar to Heat shock } \\
70 \text { kDa protein } 1\end{array}$ \\
\hline gi|000183595 & 3 & 2 & 0 & 0.00 & Uncharacterized protein \\
\hline gi|000183597 & 3 & 2 & 0 & 0.00 & Uncharacterized protein \\
\hline gi|000183599 & 3 & 2 & 0 & 0.00 & Heat shock $70 \mathrm{kDa}$ protein $1 \mathrm{~A}$ \\
\hline gi|000183600 & 3 & 2 & 0 & 0.00 & $\begin{array}{l}\text { CDNA FLJ38698 fis, clone KIDNE2002015, } \\
\text { highly similar to HEAT SHOCK } 70 \text { kDa PROTEIN } \\
1\end{array}$ \\
\hline gi|000183601 & 3 & 2 & 0 & 0.00 & $\begin{array}{l}\text { cDNA FL54370, highly similar to Heat shock } \\
70 \text { kDa protein } 1\end{array}$ \\
\hline gi|000197488 & 3 & 3 & 0 & 0.00 & $\begin{array}{l}\text { diacylglycerol kinase delta 130kDa isoform } \\
\text { CRA_a }\end{array}$ \\
\hline gi|000197489 & 3 & 3 & 0 & 0.00 & diacylglycerol kinase delta isoform 2 \\
\hline gi|000038127 & 3 & 3 & 0 & 0.00 & $\begin{array}{l}\text { beta-1,4 N-acetylgalactosaminyltransferase } 2 \\
\text { isoform b }\end{array}$ \\
\hline gi|000036282 & 3 & 2 & 0 & 0.00 & $\begin{array}{l}\text { ubiquitin carboxyl-terminal hydrolase } 46 \\
\text { isoform } 1\end{array}$ \\
\hline gi|000036283 & 3 & 2 & 0 & 0.00 & USP46 \\
\hline gi|000036284 & 3 & 2 & 0 & 0.00 & ENSP00000390102 \\
\hline gi|000118432 & 3 & 3 & 0 & 0.00 & $\begin{array}{l}\text { cDNA FL75863, highly similar to Homo } \\
\text { sapiens zinc finger protein } 432 \text { (ZNF432), } \\
\text { mRNA }\end{array}$ \\
\hline gi|000118433 & 3 & 3 & 0 & 0.00 & zinc finger protein 432 \\
\hline
\end{tabular}


Appendix 3 -Structural diagrams of AMP, ADP, ATP, AICAR, ZMP, and A-769662

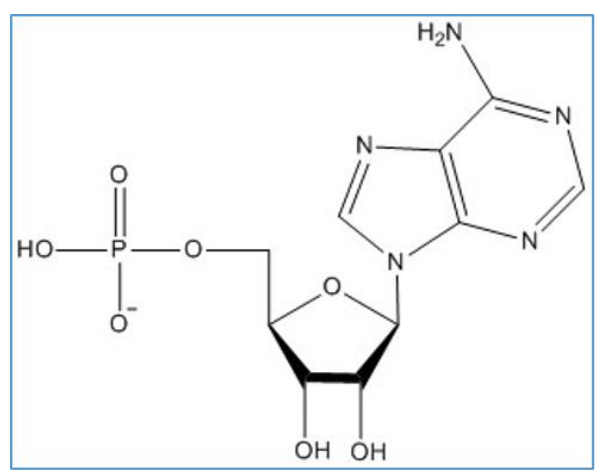

AMP

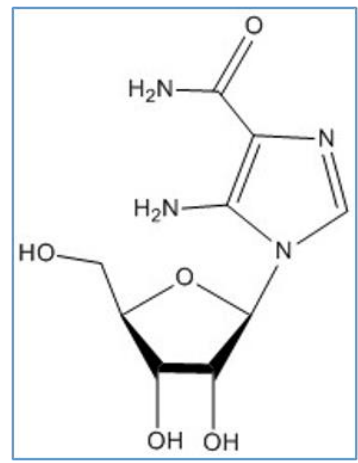

AICAR

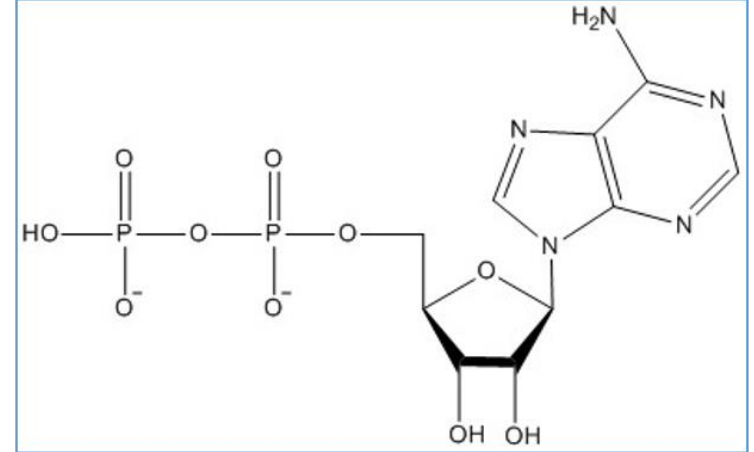

ADP

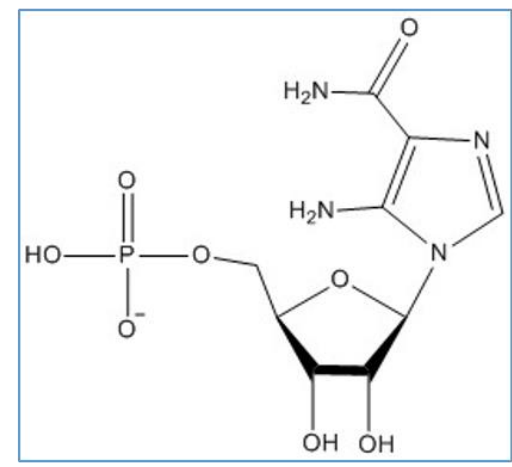

ZMP

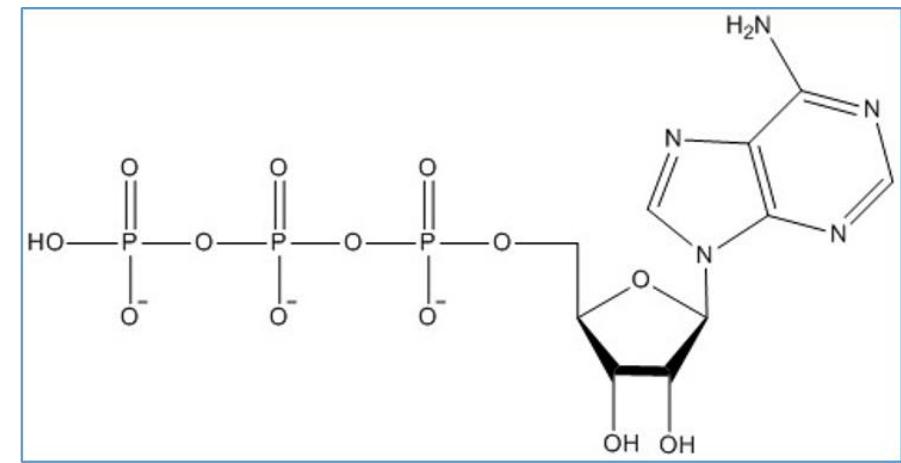

ATP

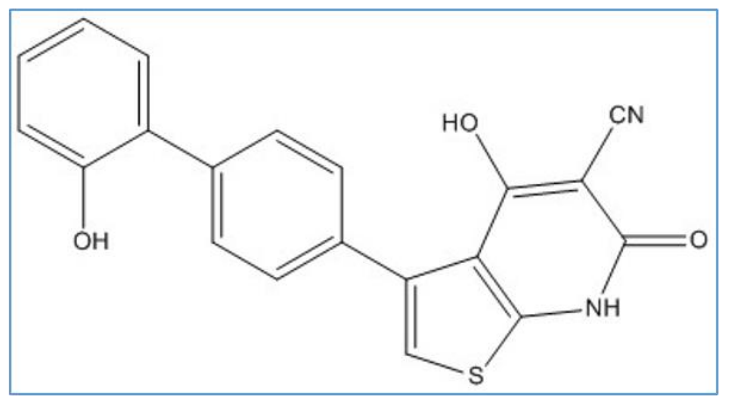

A-769662

Structures made using ChemDraw Std (PerkinElmer). 


\section{Bibliography}

Abdel-Ghany, M., Cheng, H.-C., Elble, R. C., \& Pauli, B. U. (2002). Focal adhesion kinase activated by beta(4) integrin ligation to mCLCA1 mediates early metastatic growth. The Journal of Biological Chemistry, 277(37), 34391-400. doi:10.1074/jbc.M205307200

Aguet, F., Antonescu, C. N., Mettlen, M., Schmid, S. L., \& Danuser, G. (2013). Advances in analysis of low signal-to-noise images link dynamin and AP2 to the functions of an endocytic checkpoint. Developmental Cell, 26(3), 279-91.

doi:10.1016/j.devcel.2013.06.019

Antonescu, C. N., Aguet, F., Danuser, G., \& Schmid, S. L. (2011). Phosphatidylinositol-(4,5)bisphosphate regulates clathrin-coated pit initiation, stabilization, and size. Molecular Biology of the Cell, 22(14), 2588-600. doi:10.1091/mbc.E11-04-0362

Antonescu, C. N., Danuser, G., \& Schmid, S. L. (2010). Phosphatidic Acid Plays a Regulatory Role in Clathrin-mediated Endocytosis, 21, 2944-2952. doi:10.1091/mbc.E10

Antonescu, C. N., Díaz, M., Femia, G., Planas, J. V, \& Klip, A. (2008). Clathrin-dependent and independent endocytosis of glucose transporter 4 (GLUT4) in myoblasts: regulation by mitochondrial uncoupling. Traffic, 9(7), 1173-90. doi:10.1111/j.1600-0854.2008.00755.x

Antonescu, C. N., Mcgraw, T. E., \& Klip, A. (2014). Reciprocal Regulation of Endocytosis and Metabolism. Cold Spring Harbor Perspectives in Biology, 1-20.

Aoudjit, F., \& Vuori, K. (2001). Integrin signaling inhibits paclitaxel-induced apoptosis in breast cancer cells. Oncogene, 20(36), 4995-5004. doi:10.1038/sj.onc.1204554

Assoian, R. K., \& Klein, E. a. (2008). Growth control by intracellular tension and extracellular stiffness. Trends in Cell Biology, 18(7), 347-52. doi:10.1016/j.tcb.2008.05.002

Avraamides, C. J., Garmy-Susini, B., \& Varner, J. a. (2008). Integrins in angiogenesis and lymphangiogenesis. Nature Reviews. Cancer, 8(8), 604-17. doi:10.1038/nrc2353

Bae, C. H., Kim, J. W., Ye, S. B., Song, S.-Y., Kim, Y.-W., Park, S.-Y., \& Kim, Y.-D. (2011). AMPK induces MUC5B expression via p38 MAPK in NCI-H292 airway epithelial cells. Biochemical and Biophysical Research Communications, 409(4), 669-74. doi:10.1016/j.bbrc.2011.05.062

Bakhtiar, R., \& Tse, F. L. (2000). Biological mass spectrometry: a primer. Mutagenesis, 15(5), 415-30. Retrieved from http://www.ncbi.nlm.nih.gov/pubmed/10970448

Bergers, G., \& Benjamin, L. E. (2003). Tumorigenesis and the angiogenic switch. Nature Reviews. Cancer, 3(6), 401-10. doi:10.1038/nrc1093 
Billah, S., Stewart, J., Staerkel, G., Chen, S., Gong, Y., \& Guo, M. (2011). EGFR and KRAS mutations in lung carcinoma: molecular testing by using cytology specimens. Cancer Cytopathology, 119(2), 111-7. doi:10.1002/cncy.20151

Bloch, W., Forsberg, E., Lentini, S., Brakebusch, C., Martin, K., Krell, H. W., ... Fässler, R. (1997). Beta 1 integrin is essential for teratoma growth and angiogenesis. The Journal of Cell Biology, 139(1), 265-78. Retrieved from http://www.pubmedcentral.nih.gov/articlerender.fcgi?artid=2139829\&tool=pmcentrez\&ren dertype $=$ abstract

Bourboulia, D., \& Stetler-Stevenson, W. G. (2010). Matrix metalloproteinases (MMPs) and tissue inhibitors of metalloproteinases (TIMPs): Positive and negative regulators in tumor cell adhesion. Seminars in Cancer Biology, 20(3), 161-8. doi:10.1016/j.semcancer.2010.05.002

Bowden, P., Beavis, R., \& Marshall, J. (2009). Tandem mass spectrometry of human tryptic blood peptides calculated by a statistical algorithm and captured by a relational database with exploration by a general statistical analysis system. Journal of Proteomics, 73(1), 10311. doi:10.1016/j.jprot.2009.08.004

Bretscher, M. S. (1996). Moving membrane up to the front of migrating cells. Cell, 85(4), 465-7. Retrieved from http://www.ncbi.nlm.nih.gov/pubmed/8653781

Brett, T. J., \& Traub, L. M. (2006). Molecular structures of coat and coat-associated proteins: function follows form. Current Opinion in Cell Biology, 18(4), 395-406. doi:10.1016/j.ceb.2006.06.014

Brodsky, F. M., Chen, C. Y., Knuehl, C., Towler, M. C., \& Wakeham, D. E. (2001). Biological basket weaving: formation and function of clathrin-coated vesicles. Annual Review of Cell and Developmental Biology, 17, 517-68. doi:10.1146/annurev.cellbio.17.1.517

Brooks, S. a, Lomax-Browne, H. J., Carter, T. M., Kinch, C. E., \& Hall, D. M. S. (2010). Molecular interactions in cancer cell metastasis. Acta Histochemica, 112(1), 3-25. doi:10.1016/j.acthis.2008.11.022

Bullen, J. W., Balsbaugh, J. L., Chanda, D., Shabanowitz, J., Hunt, D. F., Neumann, D., \& Hart, G. W. (2014). Cross-talk between two essential nutrient-sensitive enzymes: O-GlcNAc transferase (OGT) and AMP-activated protein kinase (AMPK). The Journal of Biological Chemistry, 289(15), 10592-606. doi:10.1074/jbc.M113.523068

Burridge, K., Nuckolls, G., Otey, C., Pavalko, F., Simon, K., \& Turner, C. (1990). Actinmembrane interaction in focal adhesions. Cell Differentiation and Development, 32(3), 337-42. Retrieved from http://www.ncbi.nlm.nih.gov/pubmed/2129156

Campbell, I. D., \& Humphries, M. J. (2011). Integrin structure, activation, and interactions. Cold Spring Harbor Perspectives in Biology, 3(3). doi:10.1101/cshperspect.a004994 
Caswell, P., \& Norman, J. (2008). Endocytic transport of integrins during cell migration and invasion. Trends in Cell Biology, 18(6), 257-263. doi:10.1016/j.tcb.2008.03.004

Caswell, P. T., Spence, H. J., Parsons, M., White, D. P., Clark, K., Cheng, K. W., .. Norman, J. C. (2007). Rab25 associates with alpha5beta1 integrin to promote invasive migration in 3D microenvironments. Developmental Cell, 13(4), 496-510. doi:10.1016/j.devcel.2007.08.012

Caswell, P. T., Vadrevu, S., \& Norman, J. C. (2009). Integrins: masters and slaves of endocytic transport. Nature Reviews. Molecular Cell Biology, 10(12), 843-53. doi:10.1038/nrm2799

Chao, W.-T., \& Kunz, J. (2009). Focal adhesion disassembly requires clathrin-dependent endocytosis of integrins. FEBS Letters, 583(8), 1337-43. doi:10.1016/j.febslet.2009.03.037

Chen, Z. P., Mitchelhill, K. I., Michell, B. J., Stapleton, D., Rodriguez-Crespo, I., Witters, L. a, ... Kemp, B. E. (1999). AMP-activated protein kinase phosphorylation of endothelial NO synthase. FEBS Letters, 443(3), 285-9. Retrieved from http://www.ncbi.nlm.nih.gov/pubmed/22989604

Chetrit, D., Barzilay, L., Horn, G., Bielik, T., Smorodinsky, N. I., \& Ehrlich, M. (2011). Negative regulation of the endocytic adaptor disabled-2 (Dab2) in mitosis. The Journal of Biological Chemistry, 286(7), 5392-403. doi:10.1074/jbc.M110.161851

Cool, B., Zinker, B., Chiou, W., Kifle, L., Cao, N., Perham, M., ... Frevert, E. (2006). Identification and characterization of a small molecule AMPK activator that treats key components of type 2 diabetes and the metabolic syndrome. Cell Metabolism, 3(6), 403-16. doi:10.1016/j.cmet.2006.05.005

Corton, J. M., Gillespie, J. G., Hawley, S. A., \& Hardie, D. G. (1995). A specific method for activating AMP-activated protein kinase in intact cells ?, 565, 558-565.

DeMali, K. a, Wennerberg, K., \& Burridge, K. (2003). Integrin signaling to the actin cytoskeleton. Current Opinion in Cell Biology, 15(5), 572-582. doi:10.1016/S09550674(03)00109-1

Desgrosellier, J. S., \& Cheresh, D. a. (2010). Integrins in cancer: biological implications and therapeutic opportunities. Nature Reviews. Cancer, 10(1), 9-22. doi:10.1038/nrc2748

Doughman, R. L., Firestone, a J., \& Anderson, R. a. (2003). Phosphatidylinositol phosphate kinases put PI4,5P(2) in its place. The Journal of Membrane Biology, 194(2), 77-89. doi:10.1007/s00232-003-2027-7

Evans, J. M. M., Donnelly, L. A., Emslie-Smith, A. M., Alessi, D. R., \& Morris, A. D. (2005). Metformin and reduced risk of cancer in diabetic patients. BMJ (Clinical Research Ed.), 330, 1304-1305. doi:10.1136/bmj.38393.572188.EB 
Ezratty, E. J., Bertaux, C., Marcantonio, E. E., \& Gundersen, G. G. (2009). Clathrin mediates integrin endocytosis for focal adhesion disassembly in migrating cells. The Journal of Cell Biology, 187(5), 733-47. doi:10.1083/jcb.200904054

Fassler, R., \& Meyer, M. (1995). Consequences of lack of beta 1 integrin gene expression in mice. Genes \& Development, 9(15), 1896-1908. doi:10.1101/gad.9.15.1896

Felding-Habermann, B. (2003). Integrin adhesion receptors in tumor metastasis. Clinical \& Experimental Metastasis, 20(3), 203-13. Retrieved from http://www.ncbi.nlm.nih.gov/pubmed/12741679

Ferla, R., Haspinger, E., \& Surmacz, E. (2012). Metformin inhibits leptin-induced growth and migration of glioblastoma cells. Oncology Letters, 4(5), 1077-1081. doi:10.3892/ol.2012.843

Filomeni, G., Cardaci, S., Da Costa Ferreira, A. M., Rotilio, G., \& Ciriolo, M. R. (2011). Metabolic oxidative stress elicited by the copper(II) complex [Cu(isaepy)2] triggers apoptosis in SH-SY5Y cells through the induction of the AMP-activated protein kinase/p38MAPK/p53 signalling axis: evidence for a combined use with 3-bromopyruvate in neur. The Biochemical Journal, 437(3), 443-53. doi:10.1042/BJ20110510

Gadalla, A. E., Pearson, T., Currie, A. J., Dale, N., Hawley, S. a., Sheehan, M., ... Frenguelli, B. G. (2004). AICA riboside both activates AMP-activated protein kinase and competes with adenosine for the nucleoside transporter in the CA1 region of the rat hippocampus. Journal of Neurochemistry, 88(5), 1272-1282. doi:10.1046/j.1471-4159.2003.02253.x

Galvez, T., Gilleron, J., Zerial, M., \& O'Sullivan, G. a. (2012). SnapShot: Mammalian Rab Proteins in Endocytic Trafficking. Cell, 151(1), 234-234.e2. doi:10.1016/j.cell.2012.09.013

Göransson, O., McBride, A., Hawley, S. a, Ross, F. a, Shpiro, N., Foretz, M., ... Sakamoto, K. (2007). Mechanism of action of A-769662, a valuable tool for activation of AMP-activated protein kinase. The Journal of Biological Chemistry, 282(45), 32549-60. doi:10.1074/jbc.M706536200

Gordon, N., \& Newton, R. W. (2003). Glucose transporter type1 (GLUT-1) deficiency. Brain and Development, 25(7), 477-480. doi:10.1016/S0387-7604(03)00058-5

Gowans, G. J., Hawley, S. a, Ross, F. a, \& Hardie, D. G. (2013). AMP is a true physiological regulator of AMP-activated protein kinase by both allosteric activation and enhancing net phosphorylation. Cell Metabolism, 18(4), 556-66. doi:10.1016/j.cmet.2013.08.019

Harburger, D. S., Bouaouina, M., \& Calderwood, D. a. (2009). Kindlin-1 and -2 directly bind the $\mathrm{C}$-terminal region of beta integrin cytoplasmic tails and exert integrin-specific activation effects. The Journal of Biological Chemistry, 284(17), 11485-97.

doi:10.1074/jbc.M809233200 
Hardie, D. G. (2011). AMP-activated protein kinase: an energy sensor that regulates all aspects of cell function. Genes \& Development, 25(18), 1895-908. doi:10.1101/gad.17420111

Hardie, G. D. (2014). AMP-activated protein kinase: a key regulator of energy balance with many roles in human disease. Journal of Internal Medicine, 1-17. doi:10.1111/joim. 12268

He, J., Xu, J., Xu, X.-X., \& Hall, R. a. (2003). Cell cycle-dependent phosphorylation of Disabled-2 by cdc2. Oncogene, 22(29), 4524-30. doi:10.1038/sj.onc.1206767

Huang, D. W., Sherman, B. T., \& Lempicki, R. a. (2009). Systematic and integrative analysis of large gene lists using DAVID bioinformatics resources. Nature Protocols, 4(1), 44-57. doi:10.1038/nprot.2008.211

Huang, X., Wullschleger, S., Shpiro, N., McGuire, V. a, Sakamoto, K., Woods, Y. L., ... Alessi, D. R. (2008). Important role of the LKB1-AMPK pathway in suppressing tumorigenesis in PTEN-deficient mice. The Biochemical Journal, 412(2), 211-21. doi:10.1042/BJ20080557

Hynes, R. (1976). Cell surface proteins and malignant transformation. Biochimica et Biophysica Acta (BBA) - Reviews on Cancer, 458(1), 73-107. doi:10.1016/0304-419X(76)90015-9

Jankowski, A., Zhu, P., \& Marshall, J. G. (2008). Capture of an activated receptor complex from the surface of live cells by affinity receptor chromatography. Analytical Biochemistry, 380(2), 235-48. doi:10.1016/j.ab.2008.05.047

Jimenez-Soto, L. F., Kutter, S., Sewald, X., Ertl, C., Weiss, E., Kapp, U., ... Haas, R. (2009). Heliobacter pylori Type IV Secretion Apparatus Exploits B1 Integrin in a Novel RGDIndependent Manner. PLoS Pathogens, 5(12), 1-14. doi:doi:10.1371/journal.ppat.1000684

Jones, M. C., Caswell, P. T., \& Norman, J. C. (2006). Endocytic recycling pathways: emerging regulators of cell migration. Current Opinion in Cell Biology, 18(5), 549-57. doi:10.1016/j.ceb.2006.08.003

Jones, R. G., Plas, D. R., Kubek, S., Buzzai, M., Mu, J., Xu, Y., ... Thompson, C. B. (2005). AMP-activated protein kinase induces a p53-dependent metabolic checkpoint. Molecular Cell, 18(3), 283-93. doi:10.1016/j.molcel.2005.03.027

Kaiser, R., Friedrich, D., Chavakis, E., Böhm, M., \& Friedrich, E. B. (2012). Effect of hypoxia on integrin-mediated adhesion of endothelial progenitor cells. Journal of Cellular and Molecular Medicine, 16(10), 2387-93. doi:10.1111/j.1582-4934.2012.01553.x

Kanellis, J., Kandane, R. K., Etemadmoghadam, D., Fraser, S. a, Mount, P. F., Levidiotis, V., ... Power, D. a. (2006). Activators of the energy sensing kinase AMPK inhibit random cell movement and chemotaxis in U937 cells. Immunology and Cell Biology, 84(1), 6-12. doi:10.1111/j.1440-1711.2005.01388.x 
Kang, M.-H., \& Banfield, B. W. (2010). Pseudorabies virus tegument protein Us2 recruits the mitogen-activated protein kinase extracellular-regulated kinase (ERK) to membranes through interaction with the ERK common docking domain. Journal of Virology, 84(17), 8398-408. doi:10.1128/JVI.00794-10

Klip, a, Schertzer, J. D., Bilan, P. J., Thong, F., \& Antonescu, C. (2009). Regulation of glucose transporter 4 traffic by energy deprivation from mitochondrial compromise. Acta Physiologica (Oxford, England), 196(1), 27-35. doi:10.1111/j.1748-1716.2009.01974.x

Kodiha, M., Rassi, J. G., Brown, C. M., \& Stochaj, U. (2007). Localization of AMP kinase is regulated by stress , cell density, and signaling through the MEK 3 ERK1 / 2 pathway, 1427-1436. doi:10.1152/ajpcell.00176.2007.

Koshiba, T., Hosotani, R., Wada, M., Miyamoto, Y., Fujimoto, K., Lee, J. U., ... Imamura, M. (1998). Involvement of matrix metalloproteinase-2 activity in invasion and metastasis of pancreatic carcinoma. Cancer, 82(4), 642-50. Retrieved from http://www.ncbi.nlm.nih.gov/pubmed/9477095

Kren, A., Baeriswyl, V., Lehembre, F., Wunderlin, C., Strittmatter, K., Antoniadis, H., ... Christofori, G. (2007). Increased tumor cell dissemination and cellular senescence in the absence of beta1-integrin function. The EMBO Journal, 26(12), 2832-42. doi:10.1038/sj.emboj.7601738

Lange, J. R., \& Fabry, B. (2013). Cell and tissue mechanics in cell migration. Experimental Cell Research, 319(16), 2418-23. doi:10.1016/j.yexcr.2013.04.023

Lee, S. K., Kim, J. H., Kim, S.-S., Kang, T., Park, N. H., Kwon, K.-H., .. Park, Y. M. (2013). Profiling and semiquantitative analysis of the cell surface proteome in human mesenchymal stem cells. Analytical and Bioanalytical Chemistry, 405(16), 5501-17. doi:10.1007/s00216013-6969-z

Liang, K.-W., Yin, S.-C., Ting, C.-T., Lin, S.-J., Hsueh, C.-M., Chen, C.-Y., \& Hsu, S.-L. (2008). Berberine inhibits platelet-derived growth factor-induced growth and migration partly through an AMPK-dependent pathway in vascular smooth muscle cells. European Journal of Pharmacology, 590(1-3), 343-54. doi:10.1016/j.ejphar.2008.06.034

Loerke, D., Mettlen, M., Yarar, D., Jaqaman, K., Jaqaman, H., Danuser, G., \& Schmid, S. L. (2009). Cargo and dynamin regulate clathrin-coated pit maturation. PLoS Biology, 7(3), e57. doi:10.1371/journal.pbio. 1000057

Longnus, S. L., Wambolt, R. B., Parsons, H. L., Brownsey, R. W., Allard, M. F., Sarah, L., \& Hannah, L. (2003). stimulates myocardial glycogenolysis by allosteric mechanisms, 6, 936944. 
Mai, A., Veltel, S., Pellinen, T., Padzik, A., Coffey, E., Marjomäki, V., \& Ivaska, J. (2011). Competitive binding of Rab21 and p120RasGAP to integrins regulates receptor traffic and migration. The Journal of Cell Biology, 194(2), 291-306. doi:10.1083/jcb.201012126

Marshall, J. F., Rutherford, D. C., McCartney, a C., Mitjans, F., Goodman, S. L., \& Hart, I. R. (1995). Alpha v beta 1 is a receptor for vitronectin and fibrinogen, and acts with alpha 5 beta 1 to mediate spreading on fibronectin. Journal of Cell Science, 108 ( Pt 3, 1227-38. Retrieved from http://www.ncbi.nlm.nih.gov/pubmed/7542669

Marshall, J., Jankowski, A., Furesz, S., Kireeva, I., Barker, L., Dombrovsky, M., ... Jackowski, G. (2004). Human Serum Proteins Preseparated by Electrophoresis or Chromatography Followed by Tandem Mass Spectrometry research articles, (Cid), 364-382.

Mettlen, M., Loerke, D., Yarar, D., Danuser, G., \& Schmid, S. L. (2010). Cargo- and adaptorspecific mechanisms regulate clathrin-mediated endocytosis. The Journal of Cell Biology, 188(6), 919-33. doi:10.1083/jcb.200908078

Miranda, L., Carpentier, S., Platek, A., Hussain, N., Gueuning, M.-A., Vertommen, D., ... Horman, S. (2010). AMP-activated protein kinase induces actin cytoskeleton reorganization in epithelial cells. Biochemical and Biophysical Research Communications, 396(3), 656-61. doi:10.1016/j.bbrc.2010.04.151

Mitchelhill, K. I., Stapletons, D., Gaob, G., House, C., Michell, B., Katsis, F., ... Kempll, B. E. (1994). Mammalian AMP-activated protein kinase shares structural and functional homology with the catalytic domain of yeast Snf1 protein kinase. The Journal of Biological Chemistry, 269, 2361-2364.

Morris, S. M., \& Cooper, J. a. (2001). Disabled-2 colocalizes with the LDLR in clathrin-coated pits and interacts with AP-2. Traffic (Copenhagen, Denmark), 2(2), 111-23. Retrieved from http://www.ncbi.nlm.nih.gov/pubmed/11247302

Muller, P. a J., Caswell, P. T., Doyle, B., Iwanicki, M. P., Tan, E. H., Karim, S., ... Vousden, K. H. (2009). Mutant p53 drives invasion by promoting integrin recycling. Cell, 139(7), 132741. doi:10.1016/j.cell.2009.11.026

Mulrooney, J. P., Hong, T., \& Grabel, L. B. (2001). Serine 785 phosphorylation of the beta1 cytoplasmic domain modulates beta1 A-integrin-dependent functions. Journal of Cell Science, 114(Pt 13), 2525-33. Retrieved from http://www.ncbi.nlm.nih.gov/pubmed/11559760

Nakano, A., Kato, H., Watanabe, T., Min, K.-D., Yamazaki, S., Asano, Y., ... Takashima, S. (2010). AMPK controls the speed of microtubule polymerization and directional cell migration through CLIP-170 phosphorylation. Nature Cell Biology, 12(6), 583-90. doi:10.1038/ncb2060 
Nakano, A., \& Takashima, S. (2012). LKB1 and AMP-activated protein kinase: regulators of cell polarity. Genes to Cells : Devoted to Molecular \& Cellular Mechanisms, 17(9), 737-47. doi:10.1111/j.1365-2443.2012.01629.x

Ong, S.-E. (2002). Stable Isotope Labeling by Amino Acids in Cell Culture, SILAC, as a Simple and Accurate Approach to Expression Proteomics. Molecular \& Cellular Proteomics, 1(5), 376-386. doi:10.1074/mcp.M200025-MCP200

Ong, S.-E. (2012). The expanding field of SILAC. Analytical and Bioanalytical Chemistry, 404(4), 967-76. doi:10.1007/s00216-012-5998-3

Ong, S.-E., Foster, L. J., \& Mann, M. (2003). Mass spectrometric-based approaches in quantitative proteomics. Methods (San Diego, Calif.), 29(2), 124-30. Retrieved from http://www.ncbi.nlm.nih.gov/pubmed/12606218

Ong, S.-E., \& Mann, M. (2006). A practical recipe for stable isotope labeling by amino acids in cell culture (SILAC). Nature Protocols, 1(6), 2650-60. doi:10.1038/nprot.2006.427

Owen, D. J., Vallis, Y., Noble, M. E. M., Hunter, J. B., Dafforn, T. R., Evans, P. R., \& Mcmahon, H. T. (1999). for the Binding of Multiple Ligands by the $\backsim$-Adaptin Appendage Domain, 97, 805-815.

Pearse, B. M. (1976). Clathrin: a unique protein associated with intracellular transfer of membrane by coated vesicles. Proceedings of the National Academy of Sciences of the United States of America, 73(4), 1255-9. Retrieved from

http://www.pubmedcentral.nih.gov/articlerender.fcgi?artid=430241\&tool=pmcentrez\&rend ertype $=$ abstract

Pellinen, T., Arjonen, A., Vuoriluoto, K., Kallio, K., Fransen, J. a M., \& Ivaska, J. (2006). Small GTPase Rab21 regulates cell adhesion and controls endosomal traffic of beta1-integrins. The Journal of Cell Biology, 173(5), 767-80. doi:10.1083/jcb.200509019

Rangaraju, V., Calloway, N., \& Ryan, T. a. (2014). Activity-driven local ATP synthesis is required for synaptic function. Cell, 156(4), 825-35. doi:10.1016/j.cell.2013.12.042

Ridley, A. J., Schwartz, M. A., Burridge, K., Firtel, R. A., Mark, H., Borisy, G., ... Ginsberg, M. H. (2003). Integrating Signals from Front to Back. Science, 302(5651), 1704-1709.

Rose, J. B., \& Coe, I. R. (2008). Physiology of nucleoside transporters: back to the future. . . Physiology (Bethesda, Md.), 23, 41-8. doi:10.1152/physiol.00036.2007

Rugg-Gunn, P. J., Cox, B. J., Lanner, F., Sharma, P., Ignatchenko, V., McDonald, A. C. H., ... Kislinger, T. (2012). Cell-surface proteomics identifies lineage-specific markers of embryoderived stem cells. Developmental Cell, 22(4), 887-901. doi:10.1016/j.devcel.2012.01.005 
Salas-Burgos, A., Iserovich, P., Zuniga, F., Vera, J. C., \& Fischbarg, J. (2004). Predicting the three-dimensional structure of the human facilitative glucose transporter glut1 by a novel evolutionary homology strategy: insights on the molecular mechanism of substrate migration, and binding sites for glucose and inhibitory molecules. Biophysical Journal, 87(5), 2990-9. doi:10.1529/biophysj.104.047886

Sato, T., Yamochi, T., Yamochi, T., Aytac, U., Ohnuma, K., McKee, K. S., ... Dang, N. H. (2005). CD26 regulates p38 mitogen-activated protein kinase-dependent phosphorylation of integrin beta1, adhesion to extracellular matrix, and tumorigenicity of T-anaplastic large cell lymphoma Karpas 299. Cancer Research, 65(15), 6950-6. doi:10.1158/00085472.CAN-05-0647

Schmid, E. M., \& McMahon, H. T. (2007). Integrating molecular and network biology to decode endocytosis. Nature, 448(7156), 883-8. doi:10.1038/nature06031

Seddon, A. M., Curnow, P., \& Booth, P. J. (2004). Membrane proteins, lipids and detergents: not just a soap opera. Biochimica et Biophysica Acta, 1666(1-2), 105-17. doi:10.1016/j.bbamem.2004.04.011

Shin, B. K., Wang, H., Yim, A. M., Le Naour, F., Brichory, F., Jang, J. H., ... Hanash, S. M. (2003). Global profiling of the cell surface proteome of cancer cells uncovers an abundance of proteins with chaperone function. The Journal of Biological Chemistry, 278(9), 7607-16. doi:10.1074/jbc.M210455200

Stephens, L. E., Sutherland, a E., Klimanskaya, I. V, Andrieux, a, Meneses, J., Pedersen, R. a, \& Damsky, C. H. (1995). Deletion of beta 1 integrins in mice results in inner cell mass failure and peri-implantation lethality. Genes \& Development, 9(15), 1883-1895.

doi:10.1101/gad.9.15.1883

Sun, W. (2012). Angiogenesis in metastatic colorectal cancer and the benefits of targeted therapy. Journal of Hematology \& Oncology, 5(1), 63. doi:10.1186/1756-8722-5-63

Tanjore, H., Zeisberg, E. M., Gerami-Naini, B., \& Kalluri, R. (2008). Beta1 integrin expression on endothelial cells is required for angiogenesis but not for vasculogenesis. Developmental Dynamics : An Official Publication of the American Association of Anatomists, 237(1), 7582. doi:10.1002/dvdy.21385

Teckchandani, A., Mulkearns, E. E., Randolph, T. W., Toida, N., \& Cooper, J. a. (2012). The clathrin adaptor Dab2 recruits EH domain scaffold proteins to regulate integrin $\beta 1$ endocytosis. Molecular Biology of the Cell, 23(15), 2905-16. doi:10.1091/mbc.E11-121007

Teckchandani, A., Toida, N., Goodchild, J., Henderson, C., Watts, J., Wollscheid, B., \& Cooper, J. a. (2009). Quantitative proteomics identifies a Dab2/integrin module regulating cell migration. The Journal of Cell Biology, 186(1), 99-111. doi:10.1083/jcb.200812160 
Ter Haar, E., Harrison, S. C., \& Kirchhausen, T. (2000). Peptide-in-groove interactions link target proteins to the beta-propeller of clathrin. Proceedings of the National Academy of Sciences of the United States of America, 97(3), 1096-100. Retrieved from http://www.pubmedcentral.nih.gov/articlerender.fcgi?artid=15533\&tool=pmcentrez\&render type $=$ abstract

Tomas, A., Futter, C. E., \& Eden, E. R. (2013). EGF receptor trafficking: consequences for signaling and cancer. Trends in Cell Biology, 24(1), 26-34. doi:10.1016/j.tcb.2013.11.002

Traub, L. M. (2009). Tickets to ride: selecting cargo for clathrin-regulated internalization. Nature Reviews. Molecular Cell Biology, 10(9), 583-96. doi:10.1038/nrm2751

Viollet, B., Athea, Y., Mounier, R., Guigas, B., Zarrinpashneh, E., Horman, S., ... Bertrand, L. (2009). AMPK: Lessons from transgenic and knockout animals. Frontiers in Bioscience (Landmark Edition), 14, 19-44. Retrieved from http://www.pubmedcentral.nih.gov/articlerender.fcgi?artid=2666987\&tool=pmcentrez\&ren dertype $=$ abstract

Washburn, M. P., Wolters, D., \& Yates, J. R. (2001). Large-scale analysis of the yeast proteome by multidimensional protein identification technology. Nature Biotechnology, 19(3), 242-7. doi: $10.1038 / 85686$

Wegener, K. L., Partridge, A. W., Han, J., Pickford, A. R., Liddington, R. C., Ginsberg, M. H., \& Campbell, I. D. (2007). Structural basis of integrin activation by talin. Cell, 128(1), 171-82. doi:10.1016/j.cell.2006.10.048

White, D. P., Caswell, P. T., \& Norman, J. C. (2007). alpha v beta3 and alpha5beta1 integrin recycling pathways dictate downstream Rho kinase signaling to regulate persistent cell migration. The Journal of Cell Biology, 177(3), 515-25. doi:10.1083/jcb.200609004

Wilde, A., Beattie, E. C., Lem, L., Riethof, D. A., Liu, S., Mobley, W. C., ... Francisco, S. (1999). Phosphorylation of Clathrin , Influencing Clathrin Redistribution and EGF Uptake, 96, 677-687.

Wu, N., Zheng, B., Shaywitz, A., Dagon, Y., Tower, C., Bellinger, G., ... Cantley, L. C. (2013). AMPK-dependent degradation of TXNIP upon energy stress leads to enhanced glucose uptake via GLUT1. Molecular Cell, 49(6), 1167-75. doi:10.1016/j.molcel.2013.01.035

Xi, X., Han, J., \& Zhang, J. Z. (2001). Stimulation of glucose transport by AMP-activated protein kinase via activation of p38 mitogen-activated protein kinase. The Journal of Biological Chemistry, 276(44), 41029-34. doi:10.1074/jbc.M102824200

Zerial, M., \& McBride, H. (2001). Rab proteins as membrane organizers. Nature Reviews. Molecular Cell Biology, 2(2), 107-17. doi:10.1038/35052055 
Zwang, Y., \& Yarden, Y. (2006). p38 MAP kinase mediates stress-induced internalization of EGFR: implications for cancer chemotherapy. The EMBO Journal, 25(18), 4195-206. doi:10.1038/sj.emboj.7601297 